\begin{abstract}
UNIVERSIDADE DE SÃO PAULO
FACULDADE DE FILOSOFIA, LETRAS E CIÊNCIAS HUMANAS

DEPARTAMENTO DE LETRAS CLÁSSICAS E VERNÁCULAS

PROGRAMA DE PÓS-GRADUAÇÃO EM FILOLOGIA E LÍNGUA PORTUGUESA
\end{abstract}

ROSANA LOURDES DE CASTRO

\title{
Concepções e práticas de leitura de formandos em Letras
}




\title{
Concepções e práticas de leitura de formandos em Letras
}

\begin{abstract}
Dissertação apresentada ao Departamento de Letras Clássicas e Vernáculas da Faculdade de Filosofia, Letras e Ciências Humanas da Universidade de São Paulo, como requisito parcial para obtenção do título de Mestre em Filologia e Língua Portuguesa, sob orientação do Prof. Dr. Manoel Luiz Gonçalves Corrêa.
\end{abstract}

Comissão Julgadora

Prof $^{\mathrm{a}}$. Dr ${ }^{\mathrm{a}}$. Angela Del Carmen Bustos Romero de Kleiman (UNICAMP)

Prof $^{a}$. Dr ${ }^{a}$. Sheila Vieira de Camargo Grillo(USP)

Prof. Dr. Manoel Luiz Gonçalves Corrêa (USP - Orientador)

$\overline{\text { Prof }^{a} \text {. Dr }}{ }^{\mathrm{a}}$. Maria Augusta Bastos de Mattos (UNICAMP - suplente)

Prof $^{\mathrm{a}} . \mathrm{Dr}^{\mathrm{a}}$. Norma Seltzer Goldstein (USP - suplente)

Prof $^{\mathrm{a}}$. Dr ${ }^{\mathrm{a}}$. Maria Lúcia da Cunha Victório de Oliveira Andrade (USP - suplente)

São Paulo, 3 de julho de 2007. 
Serviço de Biblioteca e Documentação da Faculdade de Filosofia, Letras e Ciências Humanas da Universidade de São Paulo

Castro, Rosana Lourdes de.

Concepções e práticas de leitura de formandos em Letras / Rosana Lourdes de Castro ; orientador Manoel Luiz Gonçalves Corrêa. -- São Paulo, 2007.

$121 \mathrm{f}$.

Dissertação (Mestrado - Programa de Pós-Graduação em Filologia e Língua Portuguesa. Área de concentração: Filologia e Língua Portuguesa) - Departamento de Letras Clássicas e Vernáculas da Faculdade de Filosofia, Letras e Ciências Humanas da Universidade de São Paulo.

Língua portuguesa (Estudo e ensino) - Brasil. 2. Letramento. 3. Leitura (Ensino e aprendizagem). 4. Análise do discurso (Avaliação). I. Título.

$21^{\text {a. }}$ CDD 469.79864

302.2244

C $355 \mathrm{c}$ 


\section{DEDICATÓRIA}

Dedico este trabalho ao meu filho, Henrique, à minha família e ao inesquecível amigo Jean Pièrre, por todo carinho e pelo sentido que sempre deram à minha vida. 


\section{AGRADECIMENTOS}

Ao Henrique, pela compreensão e pelo carinho.

Aos meus pais, por tudo.

Ao meu irmão Ricardo e ao meu amigo Mauro, pela ajuda que sempre me dispensaram.

Às minhas amigas Telma e Renata, pelo incentivo nos momentos de desânimo.

Ao grupo de estudos Práticas de leitura e escrita em português língua materna, pelas discussões de textos e pelas sugestões; em especial ao Orlando, por todas as palavras de apoio.

Um agradecimento especial ao professor Manoel, pela competência em sua orientação e pelo incentivo durante todo o processo de planejamento e desenvolvimento deste trabalho. 


\section{$\underline{\text { Resumo }}$}

Este trabalho tem como objetivo determinar as concepções de leitura reproduzidas nas respostas de formandos em Letras à questão discursiva de Lingüística e Língua Portuguesa do Exame Nacional de Cursos (Provão/2001). Todas as respostas analisadas, num total de duzentas e noventa, foram produzidas por universitários do município de São Paulo, oriundos de universidades públicas e privadas. A análise parte da hipótese de que os sentidos atribuídos a um texto orientam-se por diferentes concepções de leitura, as quais estão vinculadas a concepções de sujeito, de texto e de língua. Sendo as concepções de leitura verificadas em formandos do curso de Letras e considerando-se o fato de que aparecem em respostas à questão de Lingüística e Língua Portuguesa, partiu-se da hipótese de que se encontrariam nelas vestígios do embasamento teórico construído no decorrer da vida escolar, pautado, ainda que difusamente, por correntes do pensamento lingüístico divulgadas nos cursos de Letras ou assumidas no próprio ensino fundamental e médio. Partimos de estudos realizados a respeito da leitura, organizando-os em concepções denominadas, neste trabalho, como tradicional, estruturalista, cognitivista, interacional e discursiva, as quais, isoladas ou, mais freqüentemente, combinadas, reproduzem um discurso pedagógico freqüente que tem como principal finalidade a de observar falhas nos textos. Ao refletir acerca das concepções de leitura assumidas por formandos em Letras, esta pesquisa preocupa-se em lançar luz sobre o encaminhamento didático-pedagógico que esses futuros professores exemplificam em suas respostas.

Palavras-chave: concepções de leitura; práticas de leitura; texto; sentido; letramento. 


\begin{abstract}
$\underline{\text { Abstract }}$
The objective of this work is to determine the conceptions of reading in the answers of students of Languages to the discursive question of Linguistics and Portuguese of the National Examination of Courses (Provão/2001). The two hundred ninety selected answers were produced by students of the municipal district of São Paulo, from public and private universities. The analysis comes from the hypothesis that the meanings that are attributed to the text are guided by several conceptions of reading, which are not detached from the conceptions of subject, text and language. Since they are checked in the students who concluded the course of Languages, and by considering that they appear in answers to the question of Linguistics and Portuguese, the initial hypothesis was that we would meet in them some vestiges of the constructed theoretical basement pertaining to school life, based in the divulged knowledge in the courses of Languages or assumed tendencies of the linguistic thought in proper basic and high education. We started with studies regarding the reading, organizing them in conceptions, called in this work as traditional, structuralist, cognitive, interactive, and discursive, which, isolated or more frequently arranged, reproduce a frequent pedagogical speech that has as main purpose to observe imperfections in the texts. Since we think about the conceptions of reading assumed by students of Languages, this research is worried in launching light on the didactic-pedagogical approach that these future teachers mean in theirs answers.
\end{abstract}

Keywords: conceptions of reading; practical of reading; text; meaning; literacy. 


\section{$\underline{\text { Sumário }}$}

$\begin{array}{lc}\text { INTRODUÇÃO } & 10\end{array}$

I Por que a leitura? $\quad 10$

II A constituição do corpus $\quad 13$

III Primeiras hipóteses e objetivo da pesquisa 18

IV Organização do trabalho 19

CAPÍTULO I - A LEITURA NO EXAME NACIONAL DE CURSOS (PROVÃO) DE 21 LETRAS - 2001

$\begin{array}{ll}\text { I. Leitura, letramento e o Provão } & 21\end{array}$

a) Observações sobre a leitura $\quad 21$

b) Sobre letramento $\quad 22$

c) Sobre o Provão $\quad 26$

II Consideração acerca da questão, tipos de respostas e diversificação desses tipos face às 31 condições de produção do discurso

a) A questão do ENC 31

b) Tipos de respostas dos formandos $\quad 40$

c) A diversificação dos tipos de respostas: as condições de produção

CAPÍTULO II - ASPECTOS TEÓRICOS E METODOLÓGICOS 62

I Aspectos teóricos $\quad 62$

II Aspectos metodológicos: as concepções de leitura $\quad 64$

a) Concepção tradicional $\quad 64$

b) Concepção estruturalista $\quad 71$

c) Concepção cognitivista $\quad 76$

d) Concepção interacional $\quad 80$

e) Concepção discursiva

f) Considerações acerca da referência às concepções de leitura nas respostas dos formandos 86

III Procedimentos de análise $\quad 92$

CAPÍTULO III - INDÍCIOS DA PRÁTICA DE LEITURA DOS FORMANDOS 102

CONSIDERAÇÕES FINAIS 111

BIBLIOGRAFIA 


\section{$\underline{\text { Lista de anexos }}$}

Anexo A - Ofício do INEP autorizando o uso do material

Anexo B - "O outro lado da ilha" (texto integral) 


\section{$\underline{\text { Introducão }}$}

\section{Por que a leitura?}

Leitura é um assunto recorrente em nossa sociedade nos dias atuais. Quer essa atividade se relacione a formas de acesso ao mundo, à construção de sentidos do texto, à interação entre autor e leitor, à busca de sentidos depositados no texto ou até mesmo à simples decodificação, não se questiona a necessidade de sua prática no mundo atual nem se deixa de lastimar resultados insatisfatórios obtidos em exames que se ocupam de diagnosticá-la em vários países.

Pesquisar a respeito da leitura é, por sua vez, um grande desafio, principalmente por causa de sua multiplicidade de sentidos. Eleger uma definição é uma tarefa que demanda reflexão, pois as concepções de leitura variam de acordo com as distintas concepções de texto, de sujeito, de língua(gem) e de sentido, embora nem sempre sejam excludentes. Tomemos, como ponto de partida, uma definição genérica de leitura, de modo a contemplar diferentes vozes presentes nos discursos acerca desse tema. No caso do texto escrito, poderíamos pensála, conforme propõe Britto (1999, p. 6), como ação intelectiva, social e cultural, através da qual os sujeitos, em função de conhecimentos prévios, conscientes ou não, processam a informação codificada, negociando com as representações do mundo trazidas nesses textos e mobilizando as informações que constituem sua experiência de vida e aquelas fornecidas pelo autor.

Uma tal definição procura aproximar as diferentes concepções de leitura que serão abordadas neste trabalho. No entanto, devemos estar atentos ao fato de que, embora sejam vozes acerca do mesmo tema, existem nelas alguns pontos divergentes. Não podemos pensar, por exemplo, no texto como sendo, ao mesmo tempo, uma articulação lógica de pensamentos e uma dispersão de dizeres que se aliam, se opõem ou, enfim, estão relacionados ao que já foi veiculado, nem tampouco conceber o autor como plenamente consciente e, ao mesmo tempo, assujeitado.

Assim, da definição proposta, apoiando-nos em Corrêa (2006b), podemos defender a idéia de que a leitura é negociação entre representações do mundo (e entre os próprios sujeitos). Nessa negociação, o leitor mobiliza os contatos anteriores com práticas de leitura e 
escrita, mas não limita sua leitura atual a um simples cálculo entre o já conhecido e o que a ele se apresenta como novo. Suas hipóteses sobre o sentido do texto podem ser feitas, portanto, durante o processo de textualização, numa negociação que constitui, necessariamente, uma autoria para o texto. As vozes que detecta, com base nessa relação dialógica, são não apenas as que já "ouviu" ou "leu", mas também aquelas com que toma contato no momento da leitura e aquelas cuja existência pode também antecipar.

Dessa forma, a concepção discursiva foi escolhida para nortear nossas reflexões acerca da leitura, uma vez que a apresenta como atribuição de sentidos, fazendo-nos acreditar que o texto, com sua estrutura e seu conteúdo constituintes, estimula atos e reflexões que desencadeiam a produção de sentidos. Nessa produção, estão em questão vários fatores que são da instância do próprio texto, do leitor e da historicidade de ambos. Por essa razão, Orlandi (2003:1999) nos alerta para o fato de que a leitura pode ser um processo muito mais complexo do que pode parecer.

Portanto, se afirmamos que a escolha de uma definição para leitura é uma tarefa árdua é porque são múltiplas as formas de considerar o texto, seu autor e o papel do leitor. No entanto, não se pode deixar de pensar nessa questão para que demarquemos bem o ponto de vista a ser apresentado ${ }^{1}$. Embora estejamos diante de uma análise de avaliação de final de curso, teremos como foco de nossa atenção a constituição dos sujeitos envolvidos no processo discursivo, bem como a prática discursiva advinda dessa situação.

No contexto brasileiro, a leitura está mais relacionada ao fracasso que ao sucesso. Problemas referentes ao insucesso de estudantes na habilidade de leitura (e da educação, de um modo geral) são divulgados constantemente pela mídia. Em 2003, por exemplo, na pesquisa Literacy Skills for the World of Tomorrow (Alfabetização para o Mundo de Amanhã), produzida pela Unesco e pela OCDE (Organização para a Cooperação e Desenvolvimento Econômico), o Brasil ficou em $37^{\circ}$ lugar em leitura (tendo sido pesquisados 41 países). Foi divulgado, pela grande imprensa, nessa ocasião, que cerca de 50\% dos alunos brasileiros de 15 anos estavam abaixo no nível 1 de alfabetização, uma escala, criada pela Unesco, que classifica os estudantes que têm dificuldades em utilizar os instrumentos da leitura para aumentar seus conhecimentos e competências em outros assuntos. Segundo essa

\footnotetext{
${ }^{1}$ Lidamos, neste trabalho, com respostas dissertativas de formandos em Letras a uma questão sobre Língua Portuguesa e Lingüística do Exame Nacional de Cursos (Provão) de 2001.
} 
informação, metade dos brasileiros de 15 anos não conseguiam identificar, num texto, informações pontuais, evidentes ${ }^{2}$.

De acordo com o Indicador Nacional de Analfabetismo Funcional (Inaf), no Brasil, $9 \%$ da população com 15 anos ou mais é analfabeta e $66 \%$ dos que lêem não entendem textos simples. ${ }^{3}$

Por esse motivo, foram criados alguns instrumentos de avaliação - Saeb, Enem, ENC e o atual Enade (substituto do Exame Nacional de Cursos - ENC) -, os quais procuram diagnosticar, dentre outras competências, a maneira como estudantes com diferentes níveis de escolaridade lêem textos pertencentes a diversos gêneros discursivos. Essas avaliações, ao procurarem diagnosticar competências, preocupam-se com o que entendem por possibilidades da cognição humana na fase de desenvolvimento em que se encontram os sujeitos ao se submeterem a tais instrumentos.

No caso específico do Enade, um de seus principais objetivos ${ }^{4}$ é "aferir o rendimento dos alunos dos cursos de graduação em relação aos conteúdos programáticos, suas habilidades e competências". Objetivo semelhante ("avaliar os cursos de graduação da Educação Superior, no que tange aos resultados do processo de ensino-aprendizagem,"5) norteou o modelo anterior de avaliação do Ensino Superior: o antigo Exame Nacional de Cursos, que ficou conhecido como Provão, fonte do material que analisamos.

Centrando-se principalmente nos resultados obtidos numa avaliação, os dois exames (Enade e ENC), ao se proporem a conferir o rendimento dos alunos de Ensino Superior para tentarem verificar a qualidade dos cursos de graduação, deixam de considerar que uma única prova não pode fornecer um retrato fiel da aprendizagem do sujeito, ou ainda que o resultado dos alunos num exame como esse não retrataria apenas o nível dos cursos de graduação, mas também de toda a educação, já que não é somente o ensino superior o responsável pela formação do sujeito, mas também todo o percurso escolar, traçado desde a educação infantil, aliado às práticas sociais de leitura e de escrita mantidas por ele durante toda sua vida.

Além desses fatores, existe um outro a ser questionado em todos os exames nacionais que buscam avaliar o nível da educação brasileira: todos eles procuram medir, conforme já foi

\footnotetext{
${ }^{2}$ Dados encontrados em "Brasil é penúltimo de 41 países no desempenho escolar"(notícia de 01/07/2003). Disponível em: <http://www1.folha.uol.com.br/folha/educacao/ult305u13178.shtml>. Acesso em: 4 jan. 2006.

${ }^{3}$ Disponível em: <http://www.unesco.org.br/noticias/opiniao/artigow/vivamosaleitura/mostra_documento>. Acesso em: 2 out. 2006.

${ }^{4}$ Disponível em <http://www.INEP.gov.br/superior/enade/enade_oquee.htm>. Acesso em 15 mar. 2007.

${ }^{5}$ Disponível em <http://www.INEP.gov.br/superior/provao/default.asp>. Acesso em 15 mar. 2007.
} 
citado, as competências e as habilidades do sujeito, sendo que o INEP (1999, p. 7) considera por competências "as modalidades estruturais de inteligência", ou seja, as operações utilizadas para o estabelecimento de relações entre objetos, situações e fenômenos. As habilidades seriam decorrentes das competências e, ao se aperfeiçoarem, possibilitariam uma "nova reorganização das competências". Percebe-se, nesse ponto de vista, um privilégio do individual em detrimento do aspecto social envolvido na aprendizagem. Não se pensa no sujeito tendo em vista suas práticas sociais de leitura e escrita, ou seu engajamento com atividades socioculturais. Tem-se apenas a intenção de medir a competência de cada sujeito separadamente, procurando quantificar sua inteligência, algo que faz lembrar o que propõem os testes de Q.I. Assim sendo, ao se pensar em verificação de competências e habilidades em uma avaliação (Enade, Enem, Saeb), tem-se uma visão de prova como retrato da cognição do sujeito. Evidentemente, não se pode esperar que apenas um instrumento de avaliação tenha condição de aferir a cognição, o nível de leitura ou de conhecimentos, até porque tais fatores não são passíveis de quantificação.

Assim, ao analisarmos a leitura numa avaliação nacional, não temos a intenção de usar um discurso catastrofista (CORRÊA, 2006c). Não é nossa intenção lamentar resultados insatisfatórios, mas tentar compreender a prática de leitura dos formandos em Letras que se submeteram àquele exame. Acreditamos que esse discurso não traria nenhum auxílio à realidade educacional brasileira. Basta lembrar que problemas referentes ao insucesso de estudantes na habilidade de leitura (e da educação, de um modo geral) são divulgados constantemente pela mídia.

Dessa forma, pretendemos demonstrar que esses exames não podem ser vistos como definitivos, mas apenas como um recorte que busca mostrar um aspecto centrado num produto de apenas um exame da educação formal/acadêmica do sujeito.

\section{A constituição do corpus}

O corpus deste trabalho foi selecionado a partir de um corpus maior, constituído de $3363^{6}$ textos correspondentes às respostas à primeira questão do Provão de Letras de $2001^{7}$.

\footnotetext{
6 Foram recebidos 3625, mas foram desconsideradas as 262 provas que apresentavam resposta em branco.

7 Esse material foi fornecido pelo INEP (Instituto Nacional de Estudos e Pesquisas Educacionais Anísio Teixeira) ao orientador desta pesquisa. A autorização para a utilização desses dados está anexa a esse trabalho.
} 
Esses textos foram produzidos por formandos provenientes de instituições públicas (federais, estaduais e municipais) e privadas de todo o Brasil. Essas instituições são representadas por universidades, centros universitários, faculdades integradas, institutos de ensino superior e centros tecnológicos.

No que se refere à organização do material analisado neste trabalho, houve a numeração de todas as respostas selecionadas, respeitando-se a ordem em que elas se encontravam no arquivo (em formato Word) que trazia a digitação das respostas dos formandos fornecidas pela Fundação Carlos Chagas. Elas foram digitadas da maneira como foram redigidas, ou seja, não foi realizado qualquer tipo de alteração nos enunciados produzidos no Provão.

Para este trabalho, foram selecionadas, do corpus maior, as 290 (duzentas e noventa) respostas dos formandos que estudaram no município de São Paulo ${ }^{8}$. Quando se pensa na análise de dados de sujeitos representantes do município de São Paulo, pode-se cometer o engano de se considerar, em virtude do avanço tecnológico desse município, que seriam encontrados dados mais satisfatórios do que os de outros municípios. Esse tipo de olhar relaciona diretamente letramento a avanço tecnológico. Partimos da hipótese de que essa relação é um engano, pois nem o avanço tecnológico nem mesmo a simples permanência na escola garantem o domínio da leitura e da escrita por parte do sujeito. Acreditamos, com base no modelo ideológico de letramento (Street, 1994:1983), que só o investimento na qualidade educacional pode garantir bons resultados na formação de leitores capazes de compreender os mais variados gêneros textuais. Essa consideração pode ser confirmada com a verificação dos dados que fazem parte do Programa para a Avaliação Internacional de Estudantes (Pisa, na sigla em inglês), que revelam uma comparação entre os resultados obtidos por testes e questionários aplicados, em 2000, para alunos de 15 anos de 41 países. Os resultados colocam o Brasil muito perto da última posição, ao lado da Macedônia, Albânia, Indonésia e Peru. Segundo esses dados, mesmo os resultados dos melhores alunos brasileiros ficam bem abaixo dos piores estudantes dos países nas primeiras colocações. Os primeiros colocados nessa pesquisa acerca da leitura foram Finlândia, Hong Kong, Canadá, Japão e Coréia do Sul. A

\footnotetext{
${ }^{8}$ Em nosso corpus, temos 58 formandos provenientes de universidades públicas (o que corresponde a $20 \%$ do total) e 232 provenientes de universidades particulares.
} 
inclusão de Hong Kong e Coréia no topo da lista privilegiada indica, segundo Schleicher, um dos relatores dessa pesquisa, que a riqueza do país não é garantia de boa educação. ${ }^{9}$

Mesmo que haja na lista países considerados mais ricos que o Brasil, há também alguns que, apesar de problemas econômicos e de certo atraso quanto à tecnologia, estão bem próximos ou até acima da posição por ele ocupada, o que prova que não há, como afirma Graff (1995), citando Galtung ${ }^{10}$, correlação mecânica entre alfabetização e desenvolvimento:

"Que aconteceria se o mundo inteiro se tornasse alfabetizado? Resposta: não muita coisa, pois o mundo é, em grande medida, estruturado de uma forma tal que é capaz de absorver o impacto. Mas se o mundo consistisse de pessoas alfabetizadas, autônomas, críticas, construtivas, capazes de traduzir as idéias em ação, individual ou coletivamente - então o mundo mudaria".

Essas seriam realmente as grandes diferenças a serem oferecidas na educação: a consciência crítica e o engajamento social. Isso ocorrerá somente com uma busca por maior qualidade na educação, buscando não apenas manter alunos na escola, aumentar o número de estudantes nos diversos níveis de ensino ou oferecer merenda e uniforme escolar. Seria necessário, além dessas medidas, principalmente, uma maior consciência do papel social da escola: o de fornecer um ensino de qualidade para os alunos, no qual eles participem constantemente de diversas práticas de letramento e, com isso, percebam seu papel social e possam ter espaço para atuar como cidadãos participativos em sua comunidade. Evidentemente, cada sujeito, em virtude também de seus interesses e de seu convívio social, poderá ampliar seu contato com a leitura durante toda sua vida, mas não podemos nos esquecer de que a escola tem como um de seus principais papéis o de formar leitores, ou seja, sujeitos capazes de dialogar com os mais variados textos.

Mais uma comprovação para a consideração de que avanço tecnológico não está vinculado necessariamente à qualidade na educação seria a recente divulgação pela grande imprensa do resultado do SAEB 2005. Houve uma queda significativa no rendimento de estudantes da $8^{\mathrm{a}}$ série do ensino fundamental e do $3^{\circ}$ ano do ensino médio em Português. Mesmo tendo havido melhora nas notas dos alunos de $4^{\text {a }}$ série de ensino fundamental, o rendimento destes estudantes em leitura permanece num nível considerado crítico: 172,3

\footnotetext{
9 Informações retiradas de "Educação no Brasil está entre as piores, diz Unesco". Disponível em:<http://www.bbc.co.uk/portuguese/noticias/story/2003/07/030701_educaebc.shtml>. Acesso em: 03 jan. 2006.

10 GALTUNG, Johan. Literacy, Education and Schooling - for what? In: Turning Point.Ed. Bataille, p. 93. Apud: GRAFF, 1995, p. 52.
} 
pontos, numa escala de 0 a $500^{11}$. O ponto mais importante a ser considerado foi a queda do desempenho de São Paulo, tendo sido apontado como o Estado cujo desempenho mais caiu. Ao procurarem as causas para esse problema, especialistas citaram como fatores a aplicação equivocada do sistema de progressão continuada, a falta de estrutura para absorver a quantidade de estudantes e a ausência de incentivo a professores. Assim, mesmo sendo o Estado com maior avanço tecnológico, não tem conseguido elevar a qualidade da formação de seus estudantes.

Neste trabalho, ao analisarmos as respostas de formandos do município de São Paulo a uma questão discursiva do Provão de Letras de 2001 (cf. p. 31), temos como interesse a leitura realizada nesse contexto. No entanto, não pretendemos elencar dificuldades ${ }^{12}$, mas observar a que concepções de leitura esses sujeitos associam o processo de estabelecimento de sentido para o texto narrativo que compunha essa questão. A partir de tal verificação, refletiremos acerca da seguinte indagação: quais as noções que esses formandos consideram imprescindíveis para estabelecer o sentido de um texto e como essas noções são aplicadas em suas práticas de leitura? Para que isso seja possível, trabalharemos com as crenças que esses estudantes têm quanto ao estabelecimento de sentido para um texto, as quais nomearemos concepções de sentido, definidoras das concepções de leitura, bem como com a aplicação dessas concepções. Para tanto, entenderemos que toda prática de leitura envolve o estabelecimento e a aplicação de uma concepção a respeito de como se estabelece o sentido do texto. Como essas concepções não são criações individuais, mas construções sóciohistóricas que participam da constituição desses sujeitos, nem sempre são plenamente conscientes e variam de uma prática a outra. Por exemplo, no material que analisamos, quando parte dos formandos comenta a leitura que se pode fazer do texto indicado para análise na questão do Provão, essas concepções são, de algum modo, explicitadas. Contudo, quando os formandos realizam essa leitura, evidenciam uma prática múltipla no que se refere às diferentes concepções de leitura, algumas vezes distinta das anunciadas explicitamente na resposta produzida para a banca examinadora.

${ }^{11}$ Disponível em <http://www.lpp-uerj.net/olped/exibir_opiniao.asp?codnoticias=20720>. Acesso em 17 mar. 2007.

\footnotetext{
${ }^{12}$ Nossa questão não é, tampouco, a dislexia, considerada um distúrbio de origem neurológica. Ocupamonos, neste trabalho, do estudo das concepções que norteiam o estabelecimento de um sentido para o texto. Não procuraremos levantar hipóteses de como os formandos deveriam realizar a atividade leitora, mas analisaremos como essa atividade é efetivamente praticada por eles.
} 
Vale lembrar que as respostas produzidas por ocasião de um exame são marcadas por uma situação de leitura muito particular. A questão do Provão (cf. p. 31) solicitava que o formando realizasse dois tipos de leitura: uma que buscava compreender as instruções do que deveria ser respondido e outra dirigida ao texto produzido por uma menina de dez anos, que deveria ser corrigido. Assim, a análise das respostas dos formandos consiste na verificação do estabelecimento de sentido para a questão, composta pelo comando e pelo texto da menina. Com base nisso, serão também investigadas as concepções de leitura que essas práticas suscitam.

Essa análise só é possível porque a questão proposta permitia ao formando exercer três papéis distintos durante o ato de leitura: o de leitor do comando da questão que constava em sua avaliação, o de leitor de um texto que ele deveria avaliar e o de leitor de seu próprio processo de escrita. Este último refere-se ao mecanismo de transposição indicado por Corrêa (1994, p.106-7), que permite "ao autor do texto fazer-se - no processo de sua produção leitor de si mesmo". Esse mecanismo tem o "intuito de bem configurar o seu leitor”, o que, segundo Corrêa, torna "inevitável que faça interferir em sua produção, a antecipação do leitor previsto, momento em que a produção inclui, necessariamente, um procedimento de leitura". Sendo assim, esse papel relaciona-se com a produção da resposta, seguindo a imagem que o formando tem do avaliador e de si mesmo ao ser avaliado pelo Provão.

Embora se pudesse pensar que a verificação das concepções de leitura num texto escrito revela problemas de produção do texto mais do que de leitura, acreditamos, ao contrário, que toda produção textual parte de leituras e que estas, por sua vez, partem de diferentes concepções de sentido. Em outras palavras, se consideradas como práticas sociais, leitura e escrita são práticas constitutivas de letramento, diferentes entre si, mas indissociáveis. Do ponto de vista da sua realização empírica na relação entre dois sujeitos, a leitura consiste na "realização do objetivo da escrita. Quem escreve, escreve para ser lido" (CAGLIARI, 2001, p. 149). Não se deve esquecer que, do ponto de vista dos saberes envolvidos na produção do texto escrito - inclusive, freqüentemente, em relação ao do reconhecimento do código escrito -, a leitura, tanto em seu sentido amplo como em sentido restrito (leitura como decodificação), precede a produção escrita do texto.

A formação do leitor faz parte também da temática deste trabalho, uma vez que está presente em nossa proposta, quer na verificação da constituição dos leitores analisados (como se situam na sua prática de leitura), quer na consideração da função que estariam habilitados 
a exercer depois da conclusão do curso de Letras (a de professores de língua materna e, portanto, de profissionais responsáveis pela formação de novos leitores).

\section{Primeiras hipóteses e objetivo da pesquisa}

Inicialmente, pensamos em duas hipóteses a serem verificadas neste trabalho:

-H1 - o estabelecimento de uma leitura para o texto orienta-se por distintas concepções de leitura, as quais não estão desvinculadas das concepções de sujeito, de texto, de língua(gem);

-H2 - essas concepções de leitura, mesmo quando comentadas explicitamente nas respostas dos formandos, podem se afastar da prática desenvolvida pelo sujeito.

Ao levantar e verificar tais hipóteses, esta pesquisa pretende contribuir para a reflexão acerca do ensino-aprendizagem de leitura nas escolas de ensino fundamental e médio e nas universidades em relação ao ensino e à aprendizagem de leitura. Entende-se que a escola tenha como papel capacitar seus alunos a ler qualquer tipo de texto, permitindo-lhes conhecer os gêneros mais usuais em diversas práticas sociais. À faculdade, caberia aperfeiçoar o domínio dos gêneros com os quais cada um estará em intenso contato em função das exigências do ramo da atividade escolhida para sua formação. De acordo com os Parâmetros Curriculares Nacionais: Introdução $-5^{a} a 8^{a}$ séries, é necessário que as escolas centrem o ensino e a aprendizagem no desenvolvimento das capacidades que permitirão ao aluno produzir bens culturais, sociais e econômicos, em lugar de centrá-lo no conteúdo conceitual (p. 74).

Assim sendo, de acordo com os Parâmetros Curriculares Nacionais: Língua Portuguesa - $5^{a}$ a $8^{a}$ séries, acredita-se que a escola deva trabalhar para a formação de um leitor competente, ou seja, alguém que

\footnotetext{
"sabe selecionar, dentre os trechos que circulam socialmente, aqueles que podem atender a suas necessidades, conseguindo estabelecer as estratégias adequadas para abordar tais textos (...) [sendo] capaz de ler as entrelinhas, identificando, a partir do que está escrito, elementos implícitos, estabelecendo relações entre o texto e seus conhecimentos prévios ou entre o texto e outros textos já lidos"(p. 70).
}

Todos esses saberes devem ser trabalhados na escola, mas também são desenvolvidos fora dela de acordo com as práticas de leitura e escrita em que cada um se insere. Por isso, 
quanto mais intensa for a atividade cultural e mais diversificadas forem as experiências sociais do sujeito, mais facilmente ele se tornará um leitor eficiente.

\section{Organização do trabalho}

Este trabalho está organizado em três capítulos: "A leitura no Provão de Letras 2001", "Aspectos teóricos e metodológicos" e "Indícios da prática de leitura dos formandos".

No primeiro capítulo, “A leitura no Provão de Letras -2001”, será apresentada numa reflexão acerca da leitura e de seus estudos mais recentes. Será realizada uma associação entre esse tópico e o letramento, mostrando a dissociação existente entre alfabetização (pelo menos em um certo sentido de alfabetização) e leitura. Além disso, recorremos a uma exposição a respeito dos dois modelos de avaliação do Ensino Superior aplicados desde 2006: o Exame Nacional de Cursos (Provão) desde sua origem até sua extinção e substituição pelo Exame Nacional de Desempenho (Enade). Além disso, apresentaremos algumas considerações acerca da questão que suscitou as respostas analisadas neste trabalho e os tipos de respostas elaboradas pelos formandos, reveladoras das condições de produção em que eles estavam envolvidos.

O segundo capítulo, "Aspectos teóricos e metodológicos", apresentará alguns conceitos teóricos da $\mathrm{AD}$ francesa utilizados como parte central da abordagem teórica deste trabalho. Tendo como objetivo transpor aspectos teóricos referentes à leitura para a análise de nosso material, isto é, transpô-los, em nosso trabalho, como recursos metodológicos, serão apresentadas algumas concepções de leitura propostas ao longo da história. Nesse capítulo, abordaremos, ainda, a presença e a ausência de concepções de leitura nas respostas dos formandos. Dentre essas concepções, incluímos: a tradicional, a estruturalista, a cognitivista, a interacional e a discursiva, as quais foram escolhidas por representarem as principais teorias acerca da leitura e por terem sido produzidas por teóricos conceituados. No entanto, longe de pretendermos captá-las de forma explícita nos textos dos formandos, serão observadas tendo em vista as noções de texto, língua, sujeito e sentido, presentes nas respostas produzidas. Buscaremos chegar, portanto, às diferentes concepções de leitura por meio dessas noções fundamentais que norteiam a constituição de qualquer abordagem teórica sobre a leitura. É desse modo, e ligando concepção de leitura à concepção de sentido que apresentaremos a aproximação entre as várias concepções acima mencionadas por meio de parâmetros teóricos 
revelados nas concepções de sujeito, texto, língua e relação autor/leitor. Com isso, pretendemos criar condições de analisar a prática de leitura dos formandos durante a realização da prova. Os aspectos metodológicos serão apresentados também nesse capítulo para que se perceba como se pretende chegar à análise da prática de leitura realizada no Provão.

O terceiro capítulo, "Indícios da prática de leitura dos formandos", abordará os possíveis entrelaçamentos de concepções de leitura apresentadas no segundo capítulo, em função, uma vez mais, das noções de texto, língua, sujeito e sentido, presentes nas respostas produzidas pelos formandos. Essa análise dos dados levantados terá como referencial teórico a Análise do Discurso de linha francesa (AD) e partirá dos indícios encontrados nas respostas que sejam reveladores da maneira como os formandos entendem principalmente a leitura e o texto.

As "Considerações finais" trarão um apanhado dos resultados obtidos e uma reflexão final acerca da leitura, com a intenção de repensar seu ensino e sua prática. Elas serão seguidas da "Bibliografia".

Nos anexos, incluímos o Ofício do INEP com a autorização para utilização do corpus que está sendo estudado pelo projeto "O Exame Nacional de Cursos e as práticas de leitura e escrita de formandos em Letras, no qual o presente trabalho se integra, e a versão original do texto, publicada em Marcuschi (2000b) e utilizada, com pequenas alterações, na questão discursiva do Provão 2001 sobre Língua Portuguesa e Lingüística. 


\section{Capítulo I}

\section{A leitura numa questão do Exame Nacional de Cursos (Provão) de Letras - 2001}

\section{Leitura, letramento e o Provão}

\section{a) Observações sobre leitura}

A escrita mudou a relação entre o sujeito e a memória social. Por causa do domínio dessa tecnologia, a transmissão da história não se limita mais às narrativas orais contadas pelos mais experientes às crianças e aos jovens, pois permite que o sujeito projete sua cultura e seus sentimentos no papel. O saber tornou-se distanciado e disponível para a leitura dos sujeitos. Com essa mudança, surgiu a ilusão de se conseguir registrar e produzir verdades independentes dos sujeitos e dos contextos em que foram geradas, as quais seriam permanentes, absolutas, universais.

Conseguir resgatar e decodificar os fatos registrados pela escrita tornou-se importante para a humanidade. Ao longo dos séculos, conforme exposto por Cavallo e Chartier (1998), a aprendizagem da leitura e da escrita sofreu algumas alterações: na Grécia Antiga, por exemplo, realizava-se principalmente no âmbito familiar, junto a professores particulares. Antes de aprender a ler, aprendia-se a escrever. As crianças tinham de aprender as "formas" e os nomes das letras em ordem alfabética. Os estágios posteriores eram constituídos pelo traçado das sílabas, de palavras completas e, finalmente, de frases. A leitura era ensinada num segundo momento, de modo que havia indivíduos que eram capazes de escrever, mas não de ler.

Os exercícios de leitura começavam pelo reconhecimento das letras isoladas, depois pelo das sílabas e, em seguida, pelo domínio de palavras completas. Ensinar a ler consistia somente em ensinar a decodificar. Essa prática de ensino foi mantida por muito tempo e ainda hoje pode ser encontrada nas escolas. 
Por muitos séculos, a leitura/decodificação era ensinada apenas às classes sociais mais favorecidas. Apenas no século XIX, houve uma preocupação em se garantir a alfabetização em massa. A partir de então, houve a inclusão de mulheres e crianças no universo da leitura e passaram a existir novos gêneros destinados a esse novo público: livros de culinária, romance popular, revistas femininas, revistas infantis, livros de contos populares e de fadas.

Muito do avanço ocorrido na Europa no século XIX - em relação à popularização do ensino - só foi percebido no Brasil no século seguinte. Principalmente a partir do movimento escolanovista, houve consideráveis alterações no ensino de um modo geral. Seu representante mais conhecido, o educador Anísio Teixeira, trouxe para o Brasil as idéias do pedagogo e filósofo americano John Dewey e as introduziu em nossa educação a partir da década de 1930. Entre essas idéias, as duas principais eram a defesa da escola pública e gratuita e a necessidade da implantação de experiências práticas nas salas de aula.

Outras idéias que vieram para o Brasil mais recentemente foram propostas pela Associação Francesa de Leitura (AFL), uma entidade composta por pesquisadores preocupados com uma pedagogia crítica de leitura, também chamada de pedagogia da leiturização (no Brasil, pedagogia do letramento). Entre seus membros, destaca-se Roger Chartier, historiador francês e professor da École de Haute Études en Sciences Sociales, em Paris, que também integra o Instituto Nacional de Pesquisas Pedagógicas da França — INRP. A principal preocupação desse autor é a alteração da tradicional prática escolar da leitura que tem como sinônimo a simples decodificação de textos. Ele defende a concepção de leitura como prática cultural e considera que, além de historicamente variável, a relação com a leitura difere em função do meio de socialização de seus leitores.

Para a AFL, leitura diz respeito ao ato de atribuir voluntária e diretamente um significado à escrita, cuja exploração não precisa acontecer de forma linear, obedecendo à sucessão de palavras. $\mathrm{Na}$ verdade, quase sempre, o leitor realiza um movimento de antecipações e retomadas textuais, além de usar indícios não-lingüísticos para ler.

\section{b) Sobre letramento}

Sendo a leitura o cerne de nossa pesquisa, não poderíamos deixar de mencionar o letramento, ou seja, o conjunto de práticas sociais de leitura e escrita que circulam na sociedade e são mantidas pelos sujeitos (Soares, 2000). Mais associado à leitura de mundo e à 
vivência do sujeito num mundo cada vez mais influenciado pela escrita, quer na oralidade quer na escrita propriamente dita, o estudo acerca do letramento foi levado em consideração para a formulação dos Parâmetros Curriculares Nacionais de Lingua Portuguesa, os quais propõem uma mudança de enfoque em relação ao ensino de língua materna. Nesses $P C N$, entende-se por letramento "o produto da participação em práticas sociais que usam a
escrita como sistema simbólico e tecnologia. São práticas
discursivas que precisam da escrita para torná-las
significativas, ainda que às vezes não envolvam as atividades
específicas de ler ou escrever. Dessa concepção decorre o
entendimento de que, nas sociedades urbanas modernas, não
existe grau zero de letramento, pois nelas é impossível não
participar, de alguma forma, de algumas dessas práticas".
(p.19)

No Brasil, os PCN trouxeram para a educação brasileira uma maior preocupação com o letramento ideológico, apresentado por Street (1994:1983) como oposto ao que ele chama de letramento autônomo. A escrita, para o modelo autônomo, seria um produto completo em si mesmo, distinto da linguagem oral, pois estaria determinada pelo funcionamento interno ao texto escrito. Nesse modelo, o letramento é visto como uma tecnologia neutra, na qual se destaca a preocupação com o desenvolvimento da racionalidade (pensamento abstrato) e da lógica, diante do qual se formariam dois grupos cognitivamente distintos: os que sabem ler e escrever (os letrados) e os que não sabem ler nem escrever (os iletrados/analfabetos). Para Street (op. cit.), a versão moderna da teoria da grande divisa enquadra-se nesse modelo autônomo de letramento, que considera os textos escritos como causa da ascensão econômica e das habilidades cognitivas e vê a escrita como uma tecnologia que permite a descontextualização como sendo relacionada a funções lógicas superiores.

Passariam, assim, a existir usos puramente orais e usos puramente letrados da língua, e estes seriam separados, isolados, caracterizando o que se entendeu realmente por uma divisa. Em outras palavras, segundo essa tese, haveria características exclusivas para cada uma das modalidades (oral e escrita) de comunicação. No caso da oralidade, teríamos por trás um raciocínio emocional, contextualizado e ambíguo, e, no caso da escrita, um raciocínio abstrato, descontextualizado e lógico.

Já no modelo ideológico, é destacado o fato de que todas as práticas de letramento são aspectos não só culturais, mas também de estrutura de poder numa sociedade. Fala-se de 
práticas de letramento, subentendendo-se que não há apenas um tipo de letramento e que essas práticas mudam segundo o contexto.

Podendo influenciar até mesmo culturas e indivíduos que não dominam a escrita, o letramento é um processo muito mais amplo do que a alfabetização, mas que está intimamente relacionado com a existência e influência de um código escrito. Mesmo que seja analfabeto, um indivíduo, numa sociedade como a nossa, sofre influência do sistema da escrita. Por isso, existem características próprias de textos escritos presentes na fala de analfabetos.

Tfouni (1994) considera o letramento um processo de natureza sócio-histórica. Essa autora opõe-se às concepções de letramento que não são processuais nem históricas (ao modelo autônomo criticado por Street). Sua principal crítica a essas perspectivas (as quais ela nomeia a-históricas) é que, para elas, letramento tem sido tomado como sinônimo de alfabetização.

As três perspectivas a-históricas do letramento criticadas pela autora são por ela nomeadas e definidas como:

- $\quad$ individualista - enxerga o letramento como aquisição da leitura e escrita, ou seja, como sinônimo de alfabetização;

- tecnológica - considera o letramento como um produto, com seus usos em contextos altamente sofisticados, e associa os usos da leitura/escrita ao progresso da civilização e ao desenvolvimento tecnológico;

- cognitivista - refere-se ao letramento como um aprendizado decorrente das atividades mentais, vendo o indivíduo como responsável central pelo processo de aquisição da escrita e ignorando suas origens sociais e culturais.

A ênfase dessas perspectivas é colocada nas práticas, habilidades e conhecimento voltados sempre para a codificação/decodificação de textos escritos. Às vezes, de maneira apenas sugerida, aparece também uma relação entre letramento e escolarização, ensino formal.

Outra consideração aliada a essas perspectivas é a de que a escrita traz consigo conseqüências de uma ordem tal que isto modifica, de maneira radical, as modalidades de comunicação da sociedade.

Segundo uma visão mais discursiva, as práticas de letramento são constitutivas da identidade e da pessoalidade porque as formas de leitura e escrita que aprendemos e usamos estão associadas a determinadas identidades e expectativas sociais acerca de modelos de comportamentos e papéis a desempenhar. Assim, elas podem nos posicionar, mas também podem ser lugares de negociação e de transformação. 
Os estudos do letramento são de extrema importância por preocuparem-se com usos e funções sociais da leitura e da escrita. Com estes, o enfoque da pesquisa em língua materna deixa de ser apenas as questões sobre ensino-aprendizagem no contexto escolar, e vai para além dos muros da escola, para toda a sociedade, onde as pessoas precisam aplicar o que aprenderam na instituição escolar (e em todos os outros grupos sociais), tendo em vista sua realização pessoal e profissional.

A partir desse enfoque, começa-se a questionar a formação do professor de língua materna como agente de letramento na comunidade. É inegável a importância de seu papel, mas não se deve imaginar que ele possa ser o único agente, uma vez que todos os núcleos sociais têm suas práticas de leitura e escrita e, com isso, contribuem com o letramento não só das crianças, mas de todos os integrantes do grupo social.

$\mathrm{Na}$ maioria das práticas sociais, ainda hoje, o letramento dominante - práticas de leitura e escrita vistas como corretas e valorizadas pelo grupo de maior poder econômico e maior prestígio social - é apresentado como o único tipo de letramento existente. Outras práticas de letramento são apresentadas como inadequadas ou tentativas falhas de alcançar o letramento próprio da cultura dominante. No contexto enunciativo do Provão, em que se previa um modelo de resposta correta, a equipe que o elaborou - assim como em toda avaliação institucional - estava esperando uma prática de letramento dos formandos que fosse próxima à variante legitimada por ela.

Não pretendemos afirmar, a partir dos resultados obtidos pelas instituições de ensino superior, que os formandos avaliados pelo Provão estavam em um ou outro estágio de letramento $^{13}$ e que, com um maior amadurecimento, atingiriam níveis mais elevados, uma vez que, ao concordarmos com o modelo ideológico, acreditamos que, muitas vezes, resultados considerados insatisfatórios devem-se ao fato de que as práticas de letramento nunca são puras (autônomas) e o contato entre diferentes práticas pode levar a diferentes resultados. Assim, a história de inserção em certas práticas é, de fato, o que pode produzir o sucesso ou não nesse tipo de avaliação, até porque todos esses exames aliam-se muito mais ao modelo autônomo de letramento do que ao ideológico, pois, em sua grande maioria, são elaborados enfocando muito mais a escolarização do que as diversas práticas de leitura e escrita encontradas na sociedade. Diante dessa perspectiva, lançam aos avaliados questões para as quais prevêem apenas uma resposta correta, apenas um sentido aceitável (cf. aqui mesmo, o gabarito proposto pelo INEP para a questão analisada neste trabalho, p. 55-6). Com isso,

\footnotetext{
${ }^{13}$ Não é nossa intenção, neste trabalho, referirmo-nos a graus de letramento dos formandos, mas a práticas de letramento que orientam a leitura realizada no Provão.
} 
acreditam ser possível medir a capacidade de leitura e escrita de estudantes que estejam num determinado nível de escolarização a partir de um perfil de leitor/escritor pré-definido.

\section{c) Sobre o Provão}

Meneghel e Lamar (2002) lembram que:

"Devido ao enorme crescimento do número de matrículas e instituições nos anos 60 e 70, a exigência de revisão da qualidade dos cursos de graduação e a revalorização dos títulos outorgados entraram para a ordem do dia" ( p. 151).

Em virtude dessa preocupação com a qualidade do ensino desenvolvido nas inúmeras instituições de Educação Superior que surgiram nas duas últimas décadas, foi estabelecida, pela lei $\mathrm{n}^{\mathrm{o}} 9.131$, de 24 de novembro de 1995, a renovação periódica do reconhecimento dos cursos de graduação, autorizada mediante avaliações, dentre as quais um exame nacional que fosse gradativamente aplicado aos alunos em fase de conclusão desses cursos. Além da avaliação dos alunos, foi prevista, pelo Decreto $\mathrm{n}^{0}$ 2.026, de 10 de outubro de 1996, a observação de outros aspectos do ensino de graduação. Estabelecendo os procedimentos para o processo de avaliação dos cursos e instituições de educação superior, incluía uma avaliação in loco das condições em que os cursos eram ofertados (corpo docente, projeto pedagógico, infra-estrutura) e uma prova elaborada para verificar os conhecimentos específicos que os formandos teriam desenvolvido ao longo do curso de graduação. Surgia, assim, o Exame Nacional de Cursos, mais conhecido como Provão.

Em 10 de novembro de 1996, realizou-se o primeiro Exame Nacional de Cursos, que envolveu inicialmente três áreas - Administração, Direito e Engenharia Civil - com a participação de 616 cursos e 59.343 graduandos. Em seguida, a Secretaria de Educação Superior do MEC (SESu) iniciava a verificação das condições em que o ensino era ofertado nos cursos submetidos ao Exame.

Dessa forma, o Exame Nacional de Cursos foi sendo gradativamente implantado e, em 2001, por exemplo, teve a participação de mais de 4.100 cursos e cerca de 270 mil alunos (que correspondem aproximadamente a $80 \%$ de todos os graduandos do país) de 20 áreas: Agronomia, Administração, Biologia, Direito, Economia, Engenharia Civil, Engenharia 
Elétrica, Engenharia Mecânica, Engenharia Química, Farmácia, Física, Jornalismo, Letras, Matemática, Medicina, Medicina Veterinária, Odontologia, Pedagogia, Psicologia e Química.

Após a realização do quinto ENC, entendeu o MEC que toda a avaliação da educação superior (exceto a avaliação da pós-graduação) deveria estar sob a responsabilidade de um mesmo órgão: o INEP (Instituto Nacional de Estudos e Pesquisas Educacionais Anísio Teixeira).

As diretrizes para o Exame de cada área eram definidas por comissões nomeadas pelo Ministro da Educação, compostas de professores indicados por conselhos profissionais, associações de ensino e associações científicas de cada área, além do Conselho de Reitores das Universidades Brasileiras e da Secretaria de Educação Superior do MEC.

Em 2001, ano em que ocorreu o exame abordado neste trabalho, criou-se um novo critério para a atribuição de conceitos. O novo critério buscava retratar, mais detalhadamente, a realidade dos cursos de graduação. Assim, a avaliação do desempenho global dos cursos de Educação Superior incluía a consideração de diversos fatores, tais como:

- região e Unidade da Federação;

- classificação das instituições;

- grau de autonomia da instituição em relação à entidade mantenedora;

- capacidade de acesso a redes de comunicação e sistemas de informação;

- estrutura curricular adotada e sua adequação com as diretrizes curriculares nacionais de cursos de graduação;

- critérios e procedimentos adotados na avaliação do rendimento escolar;

- programas e ações de integração social;

- produção científica, tecnológica e cultural;

- condições de trabalho e qualificação docente;

- a auto-avaliação realizada pela instituição e as providências adotadas para saneamento de deficiências identificadas;

- adequação das instalações físicas gerais e específicas, tais como laboratórios e outros ambientes e equipamentos integrados ao desenvolvimento do curso;

- bibliotecas, com atenção especial para o acervo especializado, inclusive o eletrônico, para as condições de acesso às redes de comunicação e para os sistemas de informação, regime de funcionamento e modernização dos meios de atendimento.

O Exame Nacional de Cursos passou a incluir, além da prova, um questionário-pesquisa respondido anualmente pelos graduandos participantes. Os dados do questionário-pesquisa 
revelavam o perfil socioeconômico e cultural dos graduandos, suas perspectivas para o futuro profissional e acadêmico e a visão que esses alunos tinham de seus respectivos cursos, com relação ao corpo docente, currículo, infra-estrutura. Com 59 questões comuns a todos os cursos e um número variável de questões específicas, esse instrumento era composto de questões objetivas do tipo múltipla escolha, com cinco alternativas. As respostas, registradas em folhas ópticas, eram devolvidas pelos graduandos no dia do Exame.

As provas, compostas de questões objetivas - cada qual com cinco alternativas - e questões discursivas (ou compostas somente de discursivas, dependendo do curso) foram elaboradas sob a responsabilidade de um consórcio formado pela Fundação Cesgranrio e Fundação Carlos Chagas.

Outros dois questionários aplicados — um respondido pelos presentes imediatamente após a prova, o outro enviado aos coordenadores de cursos - tratavam de avaliação das provas e tinham o objetivo de obter informações a respeito da qualidade do instrumento de avaliação, com vistas ao seu aprimoramento.

O primeiro, denominado "Impressões sobre a Prova", era composto de 10 questões objetivas do tipo múltipla escolha, com cinco alternativas, e apresentado no final do caderno de prova. As respostas eram registradas na mesma folha óptica das questões da prova.

$\mathrm{O}$ segundo era um questionário com duas partes. Na primeira, solicitava-se ao coordenador que registrasse suas impressões sobre a prova como um todo. Na segunda parte, era solicitada ao coordenador de curso sua avaliação quanto à adequação dos conteúdos/habilidades que cada questão da prova pretendeu verificar.

No dia 10 de junho de 2001, das 13 às 17 horas (horário de Brasília), foram aplicadas simultaneamente, em todo o País, as provas dos 20 cursos participantes do ENC/2001. Cabe lembrar que a responsabilidade pela elaboração, aplicação e correção do exame foi atribuída à Fundação Cesgranrio e à Fundação Carlos Chagas. No entanto, para acompanhar a aplicação, o INEP credenciou observadores externos, que estiveram nos locais das provas para verificarem as circunstâncias em que se realizou o Exame e fornecer subsídios para o aperfeiçoamento do processo de aplicação das provas.

Por mais dois anos, o Exame Nacional de Cursos foi aplicado. Recebeu algumas críticas, dentre elas a de detectar as falhas dos cursos de graduação no final do processo, não permitindo que as instituições corrigissem os problemas apontados no decorrer do curso oferecido aos avaliados. Com a mudança de governo em 2003, foi alterada, em alguns pontos, a política de avaliação. Em 2004, houve a substituição do ENC por outro exame que visasse, principalmente, verificar o processo de formação dos alunos de graduação, não apenas o 
"produto final". Para tanto, foi criado, a partir da lei $\mathrm{n}^{\circ} 10.861$, de 14 de abril de 2004, o Enade $^{14}$ (Exame Nacional de Desempenho dos Estudantes).

Por estar centrado na trajetória e não no ponto de chegada, o Enade é composto por questões de baixa, média e alta complexidade, contemplando diferentes momentos da vida acadêmica do estudante. Assim sendo, ele é aplicado simultaneamente a ingressantes e concluintes, permitindo identificar o nível de ingresso e de saída dos alunos de um determinado curso, ajudando a orientar as instituições sobre a necessidade ou não de fazer ajustes ou revisões curriculares.

O Enade tem ainda questões comuns a todas as áreas do conhecimento. São questões de conhecimento geral e de ética e cidadania, consideradas, por especialistas, necessárias para a educação de todos os universitários, independentemente de suas áreas de especialização.

O reconhecimento, a renovação de reconhecimento ou o fechamento de cursos deixam de ser realizados em função apenas do desempenho dos estudantes no Exame. A nota do curso no Enade será somada à nota obtida durante a avaliação in loco, a ser feita periodicamente por comissões de especialistas nas diversas áreas do conhecimento. Como a nota do Enade não será considerada igual à qualidade do curso, ela também não será usada, para qualquer classificação das instituições.

Embora o Enade seja realizado todos os anos, a sua aplicação é feita por grupos de áreas. Esses grupos serão submetidos ao Exame somente a cada três anos, sempre com aplicação aos ingressantes e concluintes. Isto permitirá avaliar um número bem maior de áreas, além de possibilitar verificação dos ajustes feitos desde o último exame. O Enade, em três anos, atingirá 52 áreas do conhecimento, incluindo os cursos tecnológicos, sendo que o Exame Nacional de Cursos só conseguiu atingir 26 áreas.

Outra mudança em relação ao Provão é que o Enade é aplicado, sempre que possível, por amostragem. Os estudantes considerados ingressantes e concluintes são inscritos junto ao INEP pelas instituições, e o Instituto, com base em procedimento estatístico, elabora amostras, isto é, seleciona os alunos que devem participar do Exame. Sempre que o número de alunos é pequeno demais para garantir a confiabilidade dos resultados, o universo dos alunos do curso é submetido ao Enade. Uma das vantagens da amostragem seria a de permitir a obtenção de resultados confiáveis a um custo significativamente menor.

\footnotetext{
${ }^{14}$ Todas as informações referentes ao Provão foram encontradas em: RISTOFF, Dilvo e LIMANA, Amir. $O$ Enade como parte da avaliação da educação superior (2004). Disponível em: < http://www.fajopa.edu.br/banner/enade.htm>. Acesso em: 25 jun. 2005.
} 
A exemplo do que acontecia com o Exame Nacional de Curso, o Enade também solicita aos estudantes - desde os ingressantes até os concluintes - o preenchimento de um questionário sócio-econômico-cultural. O objetivo é entender como os estudantes vêem o curso quando ingressam na educação superior e como o vêem, alguns anos mais tarde, quando saem.

Muitas das perguntas feitas aos estudantes são também dirigidas aos coordenadores de curso, em questionário a ser respondido por estes, via Internet. Essa triangulação de perguntas permitirá estudos comparativos entre a compreensão dos alunos e dos coordenadores acerca dos cursos avaliados, e a compreensão que o coordenador do curso tem dos alunos e do curso como um todo, criando oportunidades para a auto-orientação acadêmica.

Dada a sua natureza, o Enade gerará diversos tipos de nota: nota de desempenho dos ingressantes na parte específica; nota de desempenho dos concluintes na parte específica; nota de ingressantes e concluintes na parte geral e comum; e nota do indicativo de valor agregado, mostrando o quanto a média de desempenho dos estudantes mudou durante a sua trajetória.

Aos estudantes de melhor desempenho no Enade o Ministério da Educação concederá estímulo, na forma de bolsa de estudos, ou auxílio específico, ou ainda alguma outra forma de distinção com objetivo similar, destinado a favorecer a excelência e a continuidade dos estudos, em nível de graduação ou de pós-graduação.

Podemos notar que a mudança na maneira de se avaliar o Ensino Superior decorreu da verificação de que a formação acadêmica não ocorre em função de um acúmulo de informações que só podem ser consideradas satisfatórias ao término do curso. A formação acadêmica, assim como toda aprendizagem, consiste num processo, num continuum, e as falhas podem ser reparadas durante os anos em que o estudante estiver se preparando para exercer uma determinada profissão. Essa é uma visão mais produtiva do que apenas lamentar as inadequações na formação de um grande grupo de estudantes e torcer para que o próximo tenha uma sorte maior em virtude apenas das alterações que cada universidade proporá ao ensino desenvolvido com seus alunos.

Mesmo assim, tendo como objetivo avaliar o rendimento de alunos do ensino superior e confrontá-lo a dados obtidos junto às instituições em que o curso de graduação foi realizado, o Enade (e também o antigo Provão) partem do pressuposto de que é possível medir conhecimento, leitura e letramento. Apesar de haver, em sua proposta, uma preocupação legítima com a qualidade do ensino e com a formação adequada de profissionais de diversas áreas do ensino superior, essas iniciativas ainda estão distante de obter o que almejam porque 
se limitam a levantar dados/conceitos, mas não prevêem - como seqüência do processo de avaliação - ações concretas na direção de atingir a qualidade almejada.

\section{Consideraç̃̃es a respeito da questão, tipos de respostas e diversificação desses tipos}

\section{face às condicões de produção do discurso}

\section{a) A questão do ENC}

A questão dissertativa sob análise pretendia verificar se o formando em Letras seria capaz de "ler e interpretar textos de diferentes gêneros e registros lingüísticos, explicitando os processos ou argumentos utilizados para justificar tal interpretação". ${ }^{15}$ Ao elaborar a questão, a equipe tinha o perfil traçado para o graduando como de alguém capaz de utilizar a língua(gem) em suas várias possibilidades, de refletir sobre elas, de desempenhar o papel de multiplicador, formando leitores e produtores de textos diversos, e de ter atitude investigativa, possibilitando um processo contínuo de construção do conhecimento.

A seguir, encontra-se a questão desencadeadora das respostas que serão analisadas neste trabalho.

O texto abaixo foi produzido por uma menina de 10 anos.

\section{O outro lado da ilha}

Essa história começa com uma família que vai a uma ilha passar suas férias. Quando eles chegam eles vão logo explorando a ilha e explodem uma barreira que os impediam de passar para o outro lado da ilha.

Quando eles foram dormir eles perceberam que os bezerros começaram a correr e que quando eles foram ver o que estava assustando os bezerros. Quando eles de repente, com uma patada só um caranguejo gigante os atacou. Débora que era sua esposa começou a chorar dizendo que queria ir embora.

Quando amanheceu eles foram ver como estava o barco, para ir embora e perceberam que o barco não estava lá. Os homens saíram para explorar a ilha, e no meio do caminho encontraram um caranguejo que estava no penhasco. Eles não quiseram saber e atiraram no caranguejo que caiu ribanceira abaixo. Mas o marido de Débora,desmaiou e seu irmão não tinha como ajudá-lo, por isso foi chamar ajuda. [...]

(In: Marcuschi, L.A. Anáfora indireta: o barco textual e suas âncoras, inédito, fragmento adaptado).

15 Provão 2001: Informativo Letras. Brasília, abril de 2001. Disponível em: <http://www.INEP.gov.br/download/enc/2001/informativos/letras.pdf>. Acesso em: 13 jul. 2005. 
Uma característica desse texto é a forma como a menina faz as ligações coesivas. Elabore um texto no qual você proponha alterações para o segundo parágrafo, apresentando três soluções para o problema dos elos coesivos. Justifique as alterações sugeridas com o apoio de noções lingüísticas. (Valor total: 35 pontos)

Para atender ao que era solicitado na questão, o formando precisaria:

$1^{\text {o }}$ - ler e interpretar o texto narrativo "O outro lado da ilha" (tomado pelos formandos como um exemplar do gênero "redação escolar");

$2^{\circ}$ - ler e interpretar a questão proposta (pertencente a um exemplar do gênero "prova");

$3^{\circ}$ - produzir um texto, que fosse uma resposta dissertativa, a partir da análise realizada do texto "O outro lado da ilha" (naturalmente, baseada em uma leitura) e do direcionamento dado na questão (três soluções para o problema dos elos coesivos no texto narrativo);

$4^{\mathrm{o}}$ - justificar tais soluções, baseando-se em conceitos lingüísticos, ou seja, trazendo para a resposta as leituras e discussões realizadas, no decorrer de sua formação, a respeito da coesão textual.

Dessa forma, a questão foi elaborada para um perfil de formando que tivesse práticas de leitura e de produção de gêneros discursivos diversos e conseguisse buscar o que neles fosse comum, uma vez que os gêneros não são estanques e estão sujeitos a aproximações. Como se pode notar, o tema da leitura está presente em cada uma das etapas requeridas para a realização do trabalho, ou seja, para a elaboração dessa resposta. Ainda que não seja o principal conteúdo lingüístico solicitado na questão, além de ler o texto e o comando da questão, o formando precisava também antecipar a leitura que seria realizada por seu leitor ideal, baseando-se na imagem que fazia do avaliador de sua resposta e procurando reativar suas leituras acerca do tema central que estava sendo avaliado: a coesão textual.

Outro fator a ser considerado para a leitura e a produção da resposta era o de ter, como em toda situação de avaliação, um tempo pré-determinado para a realização, o que sempre interfere na maneira como o sujeito terá que proceder para demonstrar seus conhecimentos. Seriam quatro horas de duração total, nas quais deveriam responder a quarenta questões de múltipla escolha, a três questões discursivas (dentre elas, a que está sendo analisada neste trabalho) e a um questionário (também de múltipla escolha) a respeito de alguns dados do formando, tais como ano em que concluiu a graduação, como avaliava o grau de dificuldade da prova etc. Outra delimitação a se considerar era a do espaço disponível para a resposta, que era de 15 linhas.

Quanto à questão propriamente dita, inicia-se com uma única informação a respeito da autora do texto. Informar a idade da menina foi uma maneira de os examinadores 
transmitirem uma imagem do sujeito que produziu o texto que seria analisado. Por outro lado, essa informação foi desencadeadora da imagem de professor que muitos formandos assumiram em seu discurso. Essa mesma imagem não seria tão freqüente, ou provavelmente nem apareceria, se o texto-base tivesse sido produzido por um adulto considerado referência na área avaliada pela questão.

A citação da fonte - um dos tipos de heterogeneidade mostrada ${ }^{16}$ indicado por AuthierRevuz (2004) - também pode ser verificada, uma vez que, além desse texto produzido pela menina, existe também a indicação de onde ele foi retirado. É a palavra do outro, no caso de Marcuschi, sendo trazida à questão como responsável pela legitimidade da indicação do texto, já que ele é uma autoridade reconhecida na área da Lingüística, ou seja, na área de conhecimento avaliada pela questão.

Apesar dessas duas indicações, não foi fornecida a situação em que o texto "O outro lado da ilha" teria sido produzido ${ }^{17}$. Os formandos poderiam deduzir que em situação escolar, pois uma história como essa normalmente seria redigida numa atividade durante uma aula de Português.

Dentre os textos que compõem nosso material, dois explicitaram o que imaginavam como condições de produção do texto-base, declarando que:

Exemplo 1. Esse texto "O outro lado da ilha" nos dá impresão de ser um típico texto narrativo contado por uma menina de 10 anos, que passou suas férias numa ilha com sua família (pressupondo

${ }^{16}$ Por heterogeneidade mostrada entendem-se as formas pelas quais o sujeito inscreve, em seu discurso, as palavras do outro. Isso pode ser demonstrado por meio de aspas, itálico ou comentário de outro discurso. Authier-Revuz dá esse nome a tal processo porque o sujeito faz questão de indicar o outro discurso que está sendo utilizado em seu próprio texto. A heterogeneidade mostrada articula-se com a heterogeneidade constitutiva da linguagem, heterogeneidade não marcada na superfície, mas passível de definir-se pela interdiscursividade, isto é, pela relação que todo discurso mantém com outros discursos.

${ }^{17}$ Uma pesquisadora de nosso grupo de pesquisa CNPQ sobre Práticas de leitura e escrita em português língua materna, coordenado pelo Prof. Dr. Manoel Luiz Gonçalves Corrêa e desenvolvido no Programa de PósGraduação em Filologia e Língua Portuguesa da FFLCH - USP, Anna Carolina Barone, conseguiu, por intermédio do professor Marcuschi, entrar em contato com a professora Mary Jane, profissional que obteve esse texto da menina durante o processo de coleta de dados para a realização de sua dissertação de mestrado - a respeito da referenciação em textos orais e escritos - pela Universidade Federal de Sergipe. Quanto às condições de produção desse texto, tratava-se de um resumo de narrativa solicitado a duas turmas de quintas séries de uma escola da rede particular de Aracaju. Ele foi realizado no segundo semestre de 2000 e compunha uma estratégia mantida, com certa freqüência, pelo professor dessas turmas: após a leitura de romances ou pequenas novelas, os alunos fariam um resumo do texto lido e, num outro momento, contariam o que leram para o professor e para os colegas.

Mary Jane acompanhou os trabalhos do professor por alguns meses e entrevistou os alunos, pedindolhes que contassem a história de que mais haviam gostado. Os alunos sabiam que ela realizava um trabalho e não se opuseram a contar as histórias. Esse processo foi realizado individualmente e gravado em fita cassete. Como um dos seus objetivos era saber como se realizava a referenciação pronominal na fala e na escrita, solicitou ao professor os textos escritos (resumos das histórias) feitos pelos alunos. Assim, o texto "O outro lado da ilha" é o resumo da leitura de um texto que tem o mesmo título e tinha um caráter de registro da leitura, significando, também, o cumprimento de uma tarefa proposta pelo professor. 
pai mãe e filhos) e, que depois a professora pediu-lhes para fazer um texto narrativo sobre suas férias. A menina escreveu como estivesse contando (oral), desse modo, para o leitor, a leitura se torna pouco esclarecedora. Ela deveria ter eliminado o excesso de pronome (eles), adjunto adverbial(quando) e substantivo (bezerro) além de procurar esclarecer as duas últimas frases do segundo parágrafo, pois o uso do "de- repente" ficou mal empregado. Seria bem vinda o esclarecimento de que os bezerros foram atacados por um caranguejo gigante, no qual reagiram com uma patada que a esposa - Débora faz parte da família citada acima. (resposta 88)

Exemplo 2. "Quando eles foram dormir, perceberam que os bezerros começaram a correr, e ao ouvirem o barulho, foram ver o que estava assustando os bezerros. De repente apareceu um caranguejo gigante, que com uma só patada, os atacou. Débora, a esposa, começou a chorar dizendo que queria ir embora. "A menina, autora do texto original, ao passar para a linguagem escrita o que havia escutado da estória, escreveu um texto não muito objetivo para quem não a conhece. Ela não especificou as personagens e a situação por completo, deixando o leitor tentar advinhar o parentesco das personagens e a situação em geral. (resposta 164)

O formando, ao elaborar essa resposta, apresentada como exemplo [1], recorreu à sua memória acerca da conhecida prática de alguns professores de iniciarem o ano letivo ou o segundo semestre de aulas propondo aos alunos para redação o tema "minhas férias". No entanto, ao associar o texto da menina a essa prática pedagógica, deixou de levar em consideração que a história contada não aconteceria na realidade com nenhuma família, já que não poderíamos encontrar um caranguejo gigante capaz de afugentar bezerros encontrados numa ilha.

Já no exemplo 2, o formando imaginou uma atividade de retextualização, segundo o que propõe Marcuschi (2003: 2000), ou seja, uma reorganização interna de um texto oral para que ele assuma as características de um texto escrito.

Assim, ao imaginarem as condições de produção do texto "O outro lado da ilha", ambos os formandos indicaram uma situação escolar, o que, de fato, era mais facilmente presumível.

No que se refere propriamente ao texto da menina, podemos notar que a autora conhece muito bem o gênero "redação", pois soube estruturar seu texto de acordo com o que comumente é solicitado nesse tipo de atividade, ou seja, produziu um texto apresentando uma situação inicial e as personagens envolvidas na história, a complicação, conflito, resolução do conflito e desfecho (cf. anexo B, p. 121).

Como todo texto, este se apresenta como uma unidade de sentido, sendo um objeto não só lingüístico, mas também histórico. Ele é resultado de um processo que produz a autoria e tem relação com outros textos e com a memória discursiva ${ }^{18}$, ou seja, com a memória dos

${ }^{18}$ Segundo Charaudeau e Maingueneau (2004), o discurso relaciona-se com a memória em dois planos complementares: o da textualidade e o da história. No nível textual, refere-se aos "saberes compartilhados pelos 
discursos sociais. Assim, é exemplo de que um discurso nasce sempre de um discurso anterior, fruto de um processo discursivo, no interior do qual todo dizer está imerso. Trata-se da presença do interdiscurso, ou seja, o conjunto de unidades discursivas com que um dado discurso tem relação implícita ou explícita (Charaudeau \& Maingueneau 2004: 286). O interdiscurso insere o discurso na história, indicando a relação que este tem com o que o antecede. Além dessa inserção na história, há também o conhecimento sociocultural ligado às experiências cognitivas vividas pelo indivíduo. Todas as narrativas, ouvidas e lidas pela menina, especialmente as de aventura, e seu conhecimento a respeito de família, de férias e de ilha integram o texto produzido por ela.

Percebe-se também que a autora do texto "O outro lado da ilha" já está familiarizada com a produção do texto narrativo. Isso pode ser notado porque ela consegue estruturar bem o gênero com que está trabalhando, apresentando um conteúdo temático (férias numa ilha) e uma estrutura composicional (a construção do enredo, com a utilização dos marcadores temporais "quando" e "de repente", e a exploração das ações, representadas pela seleção dos verbos utilizados em sua narrativa), além do estilo (considerado adequado para se apresentar uma narrativa de aventura). Além disso, podemos observar a expressividade com que a menina narra sua história, revelando também um estilo bastante característico das práticas discursivas de uma criança, bastante próximo do que se verifica comumente em redações escolares: uma mescla entre índices característicos dos textos orais bem como índices dos textos escritos que integram sua memória discursiva. É Bakhtin (2003:1979), autor que teve seus estudos explorados pelos analistas do discurso, quem considera que todo gênero caracteriza-se por refletir um conteúdo temático, uma estrutura composicional e um estilo que está

\footnotetext{
(...) indissoluvelmente ligado ao enunciado e às formas típicas de enunciados, ou seja, aos gêneros do discurso. Todo enunciado (...) é individual e por isso pode refletir a individualidade do falante (ou de quem escreve), isto é, pode ter estilo individual. Entretanto, nem todos os gêneros são igualmente propícios a tal reflexo da individualidade do falante na linguagem do enunciado, ou seja, ao estilo individual. Os gêneros mais favoráveis da literatura de ficção: aqui o estilo individual integra indiretamente o próprio edifício do enunciado, é um de seus objetivos principais (...) (BAKHTIN, 2003: 1979, p. 265)
}

interlocutores no decorrer de uma troca. Isso passa de maneira privilegiada pela anáfora”. (p. 325). No nível da história, é entendida no sentido de que toda a produção discursiva coloca em movimento formulações anteriores já enunciadas que são atualizadas no momento da enunciação. 
Assim, para Bakhtin, estilo não pode ser entendido apenas como expressividade enquanto manifestação individual. Ele responde também a coerções genéricas, que indicam as restrições para a produção de um texto pertencente a um determinado gênero.

Sendo a história uma ficção, podemos afirmar que, apesar de seguir uma determinada estrutura, apreendida nos discursos prévios, ou seja, sendo uma retomada do já-dito, a autora conseguiu ter em seu texto sua individualidade refletida. Com seu estilo marcado pelo envolvimento com a história, houve também, no momento em que as orações subordinadas adverbiais seguidas das ações das personagens foram colocadas em cadeia, a criação de certo suspense. Isso pode ser observado no segundo parágrafo, pois a tentativa de marcar a seqüência das ações ("Quando eles foram dormir eles perceberam”, "quando eles foram ver o que estava assustando os bezerros") pode ser considerada uma forma de criar uma expectativa para o que aconteceria a seguir.

A menina orienta o leitor de seu texto para o que está contando: uma história que ocorreu com uma família que decidiu passar as férias numa ilha. Nota-se que não estariam acostumados a esse tipo de passeio, já que os incidentes ocorridos revelam falta de habilidade para a vida nesse tipo de ambiente ("sua esposa começou a chorar dizendo que queria ir embora”, “atiraram no caranguejo”, “o marido de Débora desmaiou”).

Cortina (1994) afirma que todo texto apresenta, em sua organização, uma “imagem de leitor", capaz de compreender a mensagem veiculada da exata maneira como seu narrador pretendeu expressá-la. Esse "leitor ideal" está inscrito no processo formador do discurso e corresponde ao sujeito imaginário para quem o locutor dirige sua voz. Ele é parte material do discurso enunciado e pode assumir um contorno mais ou menos definido conforme seja a intenção do sujeito produtor do discurso.

No texto em questão, a menina criou uma imagem do leitor como alguém que tivesse alguns conhecimentos prévios, como, por exemplo, que uma família é composta por várias pessoas, fato que se pode inferir quando ela substitui "família" pelo pronome "eles", logo no início do texto. Esse processo - de anáfora indireta - é descrito por Marcuschi (2000b) ao analisar o mesmo texto. Segundo o autor, a anáfora indireta é produzida por meio de expressões que

"não têm um antecedente ou subseqüente referencial explícito na co-textualidade e se manifestam tanto na forma pronominal como nominal. Essas anáforas diferem das anáforas clássicas por se darem de forma indireta, ou seja, ancoradas em 
condições cognitivas, pragmáticas e se resolverem em atividades inferenciais de natureza variada e em processos de ativação e não de reativação de referentes. São muito mais freqüentes do que se imagina e não oferecem problema de compreensão" (p.1)

Alguns formandos referiram-se às anáforas indiretas como causadoras de dificuldades de estabelecimento de sentido para o texto. Isso pode ser verificado, por exemplo, na resposta 110, apresentada a seguir:

Exemplo 3. O fato de se ter escrito "uma família" e, depois, só se referir a ela pelo pronome "eles"ocasiona uma falta de coesão, pois não dá para se saber, ao certo a quem se refere "eles". Outro ponto em que ocorre falta de coesão é no trecho "...os bezerros começam a correr e que quando eles foram ver o que estava assustando os bezerros.". A menina não completou a idéia e, em seguida, mencionou "caranguejo gigante", "elemento" que não havia aparecido e que não apresenta relação alguma com o texto. A menina deixou de pensar na coesão do texto, o que poderia ser corrigido, primeiramente, pela inserção de nomes próprios (os nomes das pessoas da família) para que, em um outro momento, seja possível se ter uma idéias mais clara da mensagem que pretende ser passada.

Embora afirme que "não dá para se saber ao certo a quem se refere "eles"”. O formando percebe esse pronome como uma referência à família. Sendo assim, ele demonstra compreender esse uso da anáfora indireta.

Podemos afirmar que as anáforas indiretas ("eles", "os bezerros", "sua esposa”, "penhasco" e "ribanceira") presentes no texto "O outro lado da ilha" não oferecem problemas de compreensão, conforme postula Marcuschi (2000b). Para ele:

"Compreender uma $\boldsymbol{A I}$ corretamente é investir conhecimentos adequados buscados no contexto das âncoras oferecidas. Certamente haverá momentos de busca em que várias são as âncoras possíveis ou até mesmo ambigüidades se oferecem como em todos os casos de compreensão. Pois ao se oferecer uma descrição e explicação do aparato que subjaz ao processo de tratamento das $\boldsymbol{A I}$ não se está oferecendo ao mesmo tempo uma pílula para solução de todos os problemas inerentes ao processo". (p.20)

De um ponto de vista diferente, o da Análise do Discurso, elas relacionam-se com as formações discursivas retomadas por essa menina. Pertencem a sua memória discursiva e, segundo sua percepção, podem ser utilizadas em seu texto sem que sejam consideradas incoerências ou inadequações ao gênero em questão.

Analisando-se os três parágrafos que constituem o fragmento do texto apresentado na questão do Provão, podemos verificar que, no primeiro, além de a autora preocupar-se em situar seu leitor quanto ao que contará e do uso da anáfora indireta "eles" referindo-se à 
família, são valorizadas as ações "vão logo explorando a ilha"e "explodem uma barreira" como uma maneira bem elaborada de introduzir uma aventura e de mostrar a coerência do título, já que a família teria explodido a barreira para poder explorar o outro lado da ilha. Criase, assim, um suspense: o que haveria no outro lado dessa ilha?

No segundo parágrafo, foco da questão proposta, houve um ataque de caranguejos gigantes, o que assustou tanto os bezerros que estavam naquele local como a família. A menina, utilizando-se novamente de outras anáforas indiretas, como "os bezerros" e "sua esposa", apresenta uma complicação que teria ocorrido no passeio da família. Ela estrutura esse parágrafo, como se estivesse contando a história oralmente a seu interlocutor, mantendo, com a intercalação de orações subordinadas, a expectativa quanto ao próximo passo. Parece pretender que seu leitor, apoiado nos dados de que dispõe, infira tudo o que não está escrito, mas que, mesmo assim, está sendo contado. Sendo assim, o entendimento desse parágrafo não fica comprometido, apesar de os dois primeiros períodos estarem, do ponto de vista das convenções para produção de textos escritos, incompletos.

O terceiro parágrafo traz uma indicação de tempo que coloca ao leitor algumas dúvidas: se eles foram procurar o barco quando amanheceu, o ataque dos caranguejos teria ocorrido a que horas (durante a madrugada)? Ou teria a família passado a noite protegida em algum lugar esperando o momento em que poderia ir embora? Se a opção fosse a segunda, que lugar poderia ser esse?

Criada a segunda complicação (não encontrar o barco), inicia-se outra seqüência de ações que exploram os perigos enfrentados naquela ilha. A menina mostra que já sabe que toda aventura deve ser permeada de complicações, devendo explorar o medo de alguns personagens e a coragem de outros que salvarão a vida de todos, ou quase todos.

Ao lerem "O outro lado da ilha", os formandos poderiam mobilizar os discursos que se referem a férias em família e a aventuras numa ilha deserta. Dessa forma, tudo o que foi veiculado no texto poderia ser perfeitamente compreendido, uma vez que a autora deixou "pistas" (pertencentes ao nível pragmático-enunciativo) que podem ser resgatadas no momento da leitura ("essa história”, "uma família que vai a uma ilha passar suas férias", “explodem uma barreira que os impediam de passar para o outro lado da ilha”). Assim, conclui-se que a menina tinha como imagem de seu leitor uma pessoa mais velha ou de sua idade (professora, pais ou algum colega) e pressupunha que ele conseguisse compreender perfeitamente sua história. Por outro lado, ao lerem o texto, os formandos, também por saberem a idade da autora, formularam uma imagem do enunciador do texto como a de uma 
criança que está escrevendo uma história em que aparecem alguns pontos que devem ser corrigidos (atitude diante do texto suscitada pela própria questão).

Se observarmos a indicação do que deveria ser feito na resposta, temos uma primeira frase descritiva: "Uma característica desse texto é a forma como a menina faz as ligações coesivas". Não há, até então, nenhuma referência explícita a problemas existentes no texto "O outro lado da ilha". No entanto, as duas frases seguintes trazem dois comandos: um induz que o formando corrija o texto como se fosse o professor da menina ("proponha alterações para o segundo parágrafo, apresentando três soluções para o problema dos elos coesivos") e outro o relembra de que terá seus conhecimentos lingüísticos avaliados ("Elabore um texto" e “Justifique as alterações sugeridas com o apoio de noções lingüísticas”).

Ao formando, são, pois, apresentadas afirmações que procuravam situar a tarefa a ser realizada: elaborar um texto, propor alterações para o segundo parágrafo do texto da menina, apresentar soluções para o problema dos elos coesivos. Apesar de não haver, no comando da questão, a palavra "correção" do texto da menina, ela se torna presente na indicação de "problemas dos elos coesivos". Associando essa indicação à prática pedagógica a que foram submetidos e que muitos julgam ser a mais adequada, os formandos assumem o papel de professores que devem corrigir as falhas do texto de uma criança, vista como uma aluna hipotética. Essa associação está vinculada não só à vivência deles, mas também ao que a questão procurava verificar, ou seja, a própria questão fazia alusão à correção de textos como uma tarefa a ser realizada pelo formando, ou melhor, por um futuro professor. Essa visão do professor como corretor de textos com problemas tem sido mantida há tempos e continuará assim enquanto a elaboração de questões para esse tipo de exame permanecer com esse olhar que perpetua a consideração de problemas textuais em vez de enfatizar a observação do que já é feito corretamente para, então, buscar aperfeiçoar alguns pontos. Não foram considerados todos os conhecimentos lingüísticos que essa menina mostrou em seu texto, tendo sido apenas destacado o "problema" existente em sua produção. Evidentemente, não acreditamos que o olhar de simples corretor de textos, ou melhor, de verificador de falhas, seja o mais adequado para garantir que uma criança desenvolva a autoria de seus textos e sinta prazer em procurar elaborá-los satisfatoriamente. 


\section{b) Tipos de respostas dos formandos}

A apresentação das indicações do que deveria ser feito originou respostas estruturadas de maneiras diferentes. A seguir, estão os quatro tipos de respostas encontrados, acompanhados de exemplos:

1. apenas a reescrita ${ }^{19}$ do parágrafo ou até de todo o texto produzido pela menina;

O parágrafo deveria ser escrito da seguinte maneira:

"Quando eles foram dormir, perceberam que os bezerros começaram a correr e foram ver o que os assustava, quando, de repente, com uma só patada, um caranguejo gigante os atacou. Débora começou a chorar dizendo que queria ir embora. (resposta 9)

Certa vez uma família vai a uma ilha passar suas férias. Quando eles chegam começam a explorar a ilha e explodem uma barreira que os impediam de passar para o outro lado.

A noite foram dormir, quando acordaram com o barulho dos bezerros correndo. Foram ver o que estava acontecendo, quando se depararam com um caranguejo gigante que os atacou. Ficaram totalmente assustados, a esposa começou a chorar e dizia que queria ir embora.

Quando amanheceu eles foram em busca do barco para ir embora, e viram que o barco não estava mais lá. Ficaram desesperados e não sabiam o que fazer. (resposta 142)

Nesses tipos de respostas, os formandos reescreveram o texto ou apenas o segundo parágrafo, já realizando as alterações que julgavam importantes para que fossem bem apresentados/corrigidos os elos coesivos.

2. reescrita do parágrafo e justificativa ou comentário sobre as modificações realizadas;

Uma família vai passar as férias em uma ilha. Ao chegar é preciso explodir uma barreira que os impedem de passar.

Quando chegaram à ilha, viram que havia bezerros e caranguejos gigantes. Após se acomodaram, foram dormir.

Durante à noite, ouviram os bezerros correndo e foram verificar o que estava acontecendo. De repente viram caranguejos gigantes atacando os animais. Débora ficou apavorada, começou a chorar dizendo que queria partir da ilha.

Três soluções: uso de elementos coesivos, coerentes e concordância. Eliminação dos pronomes excedentes, pois em alguns casos são elementos vazios (elipse "Ingedore"em coesão lexical) e os mesmos são recuperados através dos verbos. Mas tudo isso não é caracterizado "erro", pois o texto foi produzido por uma criança de apenas dez anos. (resposta 138)

Quando Débora e seu marido foram dormir, perceberam que os bezerros começaram a correr, pois se sentiam assustados com suas presenças ali na ilha. De repente, um caranguejo gigante os atacou, com uma só patada, e Débora começou a chorar pois queria ir embora.

${ }^{19}$ O que chamamos aqui reescrita não corresponde ao modo como Marcuschi (2003:2000) utilizou o termo retextualização, ou seja, não se restringe à transposição de um texto oral para um texto escrito. Para nós, neste trabalho, reescrita está sendo entendida como a produção de um novo texto a partir de um ou mais textosbase, tendo em vista uma reorganização interna deste(s) buscando aperfeiçoá-lo(s), corrigi-lo(s). 


O texto desta criança apresenta determinados problemas de coesão
*Primeiramente a criança faz a apresentação de "uma família que vai para a ilha", porém não
demonstra quem são os personagens especificamente e generaliza-os: "Eles". Somente no $2^{\circ}$ parágrafo
que sintoniza quem era Débora "que era sua esposa", porém continua não esclarecendo de quem
realmente a moça era sua esposa, somente no próximo parágrafo
*Os parágrafos da criança se apresentam curtos e há várias repetições de palavras "bezerros",
"caranguejos", "quando"...
*Quando a criança faz uso do pronome pessoal do caso reto "Eles", ela não sinaliza
claramente sobre quem está escrevendo. (resposta 253)

A maior parte dos formandos optou por este tipo de resposta, em que reescrevem o parágrafo inteiro com as alterações que julgavam adequadas para o estabelecimento dos elos coesivos, procurando comentar cada mudança proposta para justificar suas opções.

3. simples apresentação das alterações possíveis para modificação dos elos coesivos;

Uma maneira de corrigir esse problema seria deixar sub entendido o pronome "eles" e retirar
também o excessivo uso do pronome relativo "que", pois poderia ser colocado que era a esposa entre
vírgulas sem o uso do pronome. (resposta 19)

No segundo parágrafo há inversões de frases, problemas de pontuação misturando assim as idéias e comprometendo a coesão do texto. (resposta 153)

Esse tipo de resposta apresenta apenas o comentário do que seria importante modificar no texto, sem qualquer justificativa para tais modificações nem demonstração de como ficaria o texto "corrigido".

4. apresentação de alterações pontuais possíveis para modificação dos elos coesivos e justificativa ou comentário sobre as modificações propostas.

A primeira solução consiste em referenciar previamente, neste mesmo parágrafo ou no
anterior, os elementos lingüísticos que aparecem no texto, como os bezerros e sua esposa, sem
antecedentes lógicos.
A segunda solução seria eliminar do texto ( $2^{\circ}$ parágrafo) a conjunção adverbial temporal
"quando"que aparece sem coesão, nos dois exemplos finais do parágrafo.
A terceira solução visa combinar as duas anteriores, adequando a introdução de elementos
lingüísticos à presença de um antecedente lógico, ou tornando-os indefinidos( uns bezerros, por
exemplo) ou eliminando-os completamente (que era sua esposa), além de reordenar as frases evitando
começá-las sempre pela mesma conjunção adverbial temporal ("quando") num jogo indefinido e
recorrente de anáforas típicas de um discurso verbal ainda não pautado inteiramente pelo controle
racional do texto escrito. (resposta 8 ) 


No segundo parágrafo, percebe-se claramente uma deficiência nas ligações entre uma oração
e outra, pois a autora não tinha conhecimento dos elos coesivos. Logo no início, deve-se retirar o
pronome "eles" em "eles perceberam", o verbo conjugado já indica o sujeito, portanto colocar uma
vírgula apenas é a melhor opção a fim de separar orações e idéias. Posteriormente, em "e que quando
eles" pode se substituir pela conjugação "então" ou "por isso". No único da outra oração "Quando eles
de repente", pode-se trocar por "Ao chegarem lá, repentinamente, foram atacados..." ou, também
pode-se apenas retirar o "Quando eles", que esta deslocado na frase, não possuindo significância. Na
mesma oração, deveria haver outra vírgula após o "patada só", já que a ordem normal da oração foi
invertida. E ainda há ambiguidade no final dessa mesma oração "gigante os atacou". Atacou a quem?
A família ou aos bezerros? Portanto, deve-se dizer "atacou a família". Na última oração, não é correto
explicar quem é Débora, já que nenhuma das personagens foram apresentadas. (resposta 45)

Neste tipo de resposta, os formandos indicam quais poderiam ser as modificações pontuais no texto produzido pela menina, procurando justificá-las a partir do conhecimento que julgavam legitimado pela banca examinadora.

Nosso corpus apresentou as estruturas de respostas da seguinte maneira:

Gráfico das estruturas apresentadas nas 290 respostas analisadas.

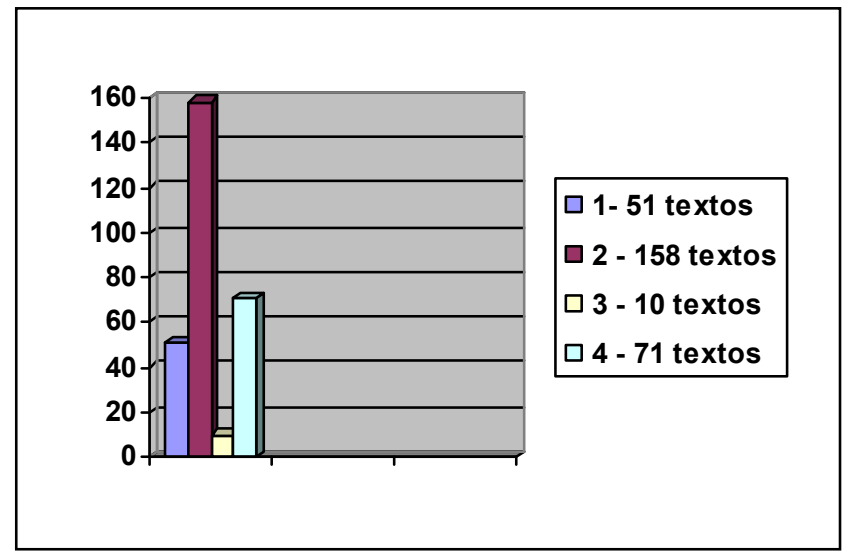

1. apenas a reescrita do parágrafo ou até de todo o texto produzido pela menina;

2. reescrita do parágrafo e justificativa ou comentário das modificações realizadas;

3. apresentação das alterações possíveis para modificação dos elos coesivos;

4. apresentação de alterações pontuais possíveis para modificação dos elos coesivos e justificativa ou comentário sobre as modificações propostas.

Verificamos, portanto, que poucos foram os formandos que apenas apontaram o que imaginavam ser os problemas referentes aos elos coesivos no texto da menina. Grande parte deles apontou esses problemas ou reescreveu o texto procurando eliminá-los. Os comentários e justificativas também estão presentes, como pode ser observado, na maior parte das respostas. Podemos afirmar que as estruturas 2 e 4 são perfeitamente adequadas em relação à questão. Esses tipos de reescrita são decorrentes da proposta.

Essa diversidade na estrutura das respostas está associada, como dissemos, à maneira como a questão foi proposta. No entanto, não deixa de estar ligada também às práticas 
discursivas a que esses formandos foram expostos durante sua vida escolar/acadêmica. A maioria dos leitores da questão considerou duas possibilidades:

a- produção de texto apenas com o comentário das possíveis alterações para o texto lido buscando corrigir os "problemas dos elos coesivos" indicados no comando (sendo esta interpretação mais "presa" ao aspecto literal da questão); ou

b- $\quad$ reescrita do texto, inserindo nele as correções imaginadas como adequadas para depois justificá-las (esta interpretação está mais próxima da alusão, feita na questão, ao papel de professor que deveria ser assumido em relação ao texto em análise).

No entanto, encontramos algumas respostas em que os formandos apenas reescreveram o segundo parágrafo ou até todo o texto, sendo que alguns procuraram continuar a história do ponto em que ele foi interrompido. Esses alunos reproduziram práticas extremamente comuns no ensino fundamental e até mesmo no ensino médio, sem terem revelado um maior envolvimento com práticas que deveriam ter sido vistas nos cursos de Letras: de análise de textos para, por exemplo, a verificação de suas condições de produção, de suas estruturas composicionais e de seus conteúdos temáticos. As respostas em que só foram mostradas as possíveis soluções para os "problemas dos elos coesivos" também estão distantes do que deveria ser hábito desses formandos: associar as "correções" sugeridas a estudos lingüísticos desenvolvidos no ensino superior e não apenas a seus conhecimentos, por vezes precário, da gramática normativa.

\section{c) A diversificação dos tipos de resposta: as condições de produção}

Já sabemos que a questão analisada neste trabalho integrava uma avaliação de conclusão de curso. Nessas condições de produção, temos como sujeitos envolvidos os formandos, os examinadores (grupo de profissionais que elaborou e/ou corrigiu a prova, o qual, mesmo que não tenha sido composto pelos mesmos sujeitos, representava o mesmo lugar enunciativo: o da instituição) e a menina de dez anos cujo texto foi apresentado como base para a questão.

As condições de produção foram primeiramente anunciadas por Pêcheux em 1969. Na formulação de Charaudeau \& Maingueneau (2004), são as "situações objetivas do locutor e 
de seu interlocutor (...) desdobradas em representações imaginárias dos lugares que um atribui ao outro" (p.114).

Assim, segundo a Análise Automática do Discurso (AAD-69), proposta por Pêcheux, nos processos discursivos, existe uma série de formações imaginárias que designam o lugar que A e B se atribuem a si e ao outro, e a imagem que fazem de seu lugar e do lugar do outro (GADET e HAK, 2001: 1997, p.82).

Em outras palavras, os sujeitos imaginam para si e para o outro diferentes lugares para a produção de seus discursos. Orlandi (2003) indica que existem

\begin{abstract}
"a imagem da posição sujeito locutor (quem sou eu para lhe falar assim?) mas também da posição sujeito interlocutor (quem é ele para me falar assim, ou para que eu lhe fale assim?) e também a do objeto do discurso (do que estou lhe falando, do que ele me fala?). É pois todo um jogo imaginário que preside a troca de palavras. E se fazemos intervir a antecipação, este jogo fica ainda mais complexo pois incluirá: a imagem que o locutor faz da imagem que seu interlocutor faz dele, a imagem que o interlocutor faz da imagem que ele faz do objeto do discurso e assim por diante" ( p. 40).
\end{abstract}

Além desse jogo de formações imaginárias, podemos levar em consideração também a cenas enunciativas propostas por Maingueneau (2004: 2001), as quais também estão associadas às condições de produção. Aplicando essas cenas ao contexto enunciativo do Provão, podemos considerar que os formandos em Letras avaliados em 2001 estavam envolvidos em três cenas:

- a cena englobante, ou seja, o tipo do discurso (escolar);

- a cena genérica, ou seja, o gênero do discurso (prova);

- a cenografia, ou seja, " a fonte do discurso e aquilo que ele engendra" "20 (situação de avaliação institucional, envolvendo uma questão dissertativa a respeito de conhecimentos lingüísticos).

Quanto às cenas englobante e genérica, elas definem o que Maingueneau (op. cit., p.87) chama quadro cênico, considerado "o espaço estável no interior do qual o enunciado adquire sentido". No entanto, esse autor afirma que o primeiro contato que o leitor tem não é com nenhuma das duas cenas, mas com a cenografia, sendo esta, em especial, muito importante para nossa análise porque ela se relaciona à simulação de papéis sugerida pela

\footnotetext{
${ }^{20}$ Maingueneau, op. cit., p. 87.
} 
própria questão e assumida pelos formandos. Para alguns deles, no entanto, essa cenografia sugerida não é correspondente à cena genérica, uma vez que o papel assumido pelo leitor como de professor corretor de um texto é diferente do que poderia ser verificado na cena genérica que temos: uma avaliação. Nessa cena genérica, comumente, teríamos apenas sujeitos se submetendo a uma avaliação, o que, embora realmente ocorra, não é verificado na cenografia construída.

Assim sendo, a cenografia seria uma encenação capaz de conferir credibilidade à enunciação. Dela faz parte o enunciado, o modo como o enunciador se inscreve no tempo e no espaço de seu interlocutor e as determinações sintáticas e semânticas que contribuem para forjar a imagem que os parceiros se atribuem um ao outro no ato de comunicação. Nesse contexto, a noção de ethos ${ }^{21}$ adquire, para Maingueneau, toda sua importância.

Assim, consideramos que os formandos, ao compreenderem que estavam sendo avaliados enquanto futuros professores, estavam presumindo essa imagem baseando-se na cenografia e não no quadro cênico.

Outro fator a ser observado é que nenhum discurso se dá numa relação simétrica entre os participantes. Dá-se numa relação de dominância, sempre havendo entre os interlocutores uma relação de poder. Além dessa relação de poder, podemos considerar também o maior ou menor domínio a respeito do tema atribuído pelo interlocutor a si mesmo e ao(s) outro(s).

A situação de avaliação marca bem a assimetria entre os sujeitos (avaliador e avaliado). No entanto, o papel de avaliador é atribuído também ao formando a partir do momento em que, como futuro professor, deve apontar e corrigir falhas no texto de uma criança. Assim, o texto dele é avaliado pelo examinador enquanto ele avalia o texto da menina. Esses papéis exercidos partem da imagem que cada sujeito (formando e examinador) tem de seu papel e do outro (formações imaginárias, segundo Pêcheux). A esses papéis atribuídos aos e pelos sujeitos dá-se o nome de simulacros $^{22}$, os quais se fazem bem explícitos, por exemplo em [4], resposta que é um bilhete para a menina como se o formando fosse seu professor:

Exemplo 4. Caro aluno(a) mesmo reconhecendo que sua imaginação é notória pra sua idade, observo que o seu texto não têm coerência pela falta dos conectores, de conjunções imprescendíveis num relato coeso. Após iniciar seu texto com a introdução, que está correta, faltou atenção na descrição do

\footnotetext{
21 Ethos é modo de presença, a imagem do sujeito depreendida no enunciado (Maingueneau, 1989).

22 Os simulacros fundamentam a comunicação e revelam a enunciação. Consistem nos papeís atribuídos aos/pelos sujeitos e revelam um contrato fiduciário (da ordem do fazer-crer) entre os sujeitos do discurso. Assim, o sujeito assume um determinado papel para fazer o outro acreditar ou não em algo (cf. Greimas, apud BARROS, 2002, p. 64).
} 
ambiente e elementos de concordância na frase do $2^{\circ}$ parágrafo. Procure após apresentar uma introdução num texto fazer um desenvolvimento nítido para que chegue a uma conclusão, não deixe frases soltas. Ex: na frase do seu texto"...e quando eles foram ver o quê estavam assustando os bezerros"; faltou o complemento para dar coesão, que podia ser assim: "...perceberam que era um grande carangueijo"./. Se ele não tinha como ajudá-lo, por isso foi buscar ajuda"isto é antitese, ";e uma contradição. Por isso procure reescrever seu texto usando elementos coesivos como: mas, e, porém, depois etc... assim haverá coesão e coerência no seu texto. (resposta 96)

A própria questão colocava o escrevente nesse jogo de simulação de papéis: ora deveria ser aluno ora professor. Em outras palavras, a cena genérica (prova) estava associada a essa simulação de papéis construída na cenografia.

Assim, esse formando, ao dirigir-se à menina como se ela fosse sua aluna, o que pode ser verificado logo no início da resposta em virtude do uso de "caro aluno(a)", valoriza alguns aspectos de sua produção, elogiando sua imaginação, - "sua imaginação é notória pra sua idade"- mas aponta vários problemas em seu texto, dando algumas sugestões para resolvê-los. Ora, essa é uma intervenção muito freqüente entre professores, o que comprova que esse formando assume um dos papéis que a questão sugere. Ao assumi-lo, atribui à menina o de aluna que, por ser muito nova, não teria muita imaginação nem conhecimento necessário para a produção de um texto considerado por ele satisfatório. As escolhas que esse formando fez têm relação com o lugar que ele quer ocupar diante da instituição.

O lugar a partir do qual o sujeito produz seu discurso é constitutivo do que ele diz. Por isso, a escolha desse lugar por parte do formando, que aparece no discurso como uma posição enunciativa, é extremamente importante para indicar a imagem que ele espera que o examinador faça dele. Imaginando ser a posição enunciativa do professor mais respeitada do que se ele se mantivesse na posição enunciativa de aluno, essa resposta indica uma tentativa do aluno de se aproximar do lugar que ele julga mais adequado para a produção de seu discurso.

Temos, então, que considerar a construção da imagem dos interlocutores como uma distribuição de papéis, diante da qual o locutor pode escolher, mais ou menos livremente, sua cenografia.

Isso pôde ser verificado em muitas das respostas em que se propuseram alterações na história contada pela menina, com uma correção que, muitas vezes, alterou completamente o texto "O outro lado da ilha". Algumas dessas respostas encontram-se a seguir:

Exemplo 5. Ao amanhecer todos saíram para ver como estava o barco, e perceberam que este estava completamente destruído e não daria mais para irem embora, a menos que construíssem outro barco.

Todos foram para a floresta buscar madeira e cipó, ao retornarem encontraram um carangueijo enorme e assustador, sem parar para pensar, todos o mesmo tempo atiraram, matando assim o 
caranguejo, as mulheres ficaram assustadíssimas e entraram em pânico, com medo de que viesse a família do caranguejo para vingar.

Construiram uma jangada rapidamente e conseguiram sair daquela ilha dos horrores. (resposta 23)

Nesse exemplo, o formando continuou a história da menina em vez de alterar o segundo parágrafo, conforme solicitava a questão. Ele reproduz, dessa forma, uma situação já vivenciada na escola, estando mais "preso" ao que se refere à cena englobante, ou seja, ao discurso escolar - com o qual manteve contato - considerado por ele mais significativo. No exemplo seguinte, o formando também continuou o texto a partir do segundo parágrafo:

Exemplo 6. O irmão de Debora foi buscar ajuda porque com o tamanho do caranguejo seu cunhado desmaiou e não conseguindo carrega-lo, porque com o tamanho do caranguejo correu e machucou o pé na pedra e estava com dificuldade para andar; mas ele conseguiu arrastar o seu cunhado para um canto até chegar ajuda. Depois de um certo tempo encontrou os outros e foram até o ferido.

E com a ajuda de todos seu cunhado ou seja o marido de Debora voltou em si com alguns remédios que levaram para emergência. E logo em seguida começaram à procura do barco que havia sumido, quando derrepente avistaram deduziram com a força do mar a corda rebentou levando o barco para longe. A sorte que Debora é uma campeã de natação é foi até o barco e o trouxe de volta e todos foram embora muito felizes, porque estava saindo da ilha assustadora. (resposta 140)

Essa resposta também está mais associada à cena englobante, à imagem que o formando assume para si como de um aluno sendo avaliado numa situação escolar, já que continuar textos costuma ser uma atividade solicitada nas aulas de redação do ensino fundamental e até mesmo no ensino médio, mas não seria prevista para uma avaliação no nível adequado para o ensino superior. Assim, a relação desses exemplos [5] e [6] com a cena genérica torna-se muito tênue, pois, embora esse tipo de atividade já possa ter sido avaliada em sua vida escolar, não seria esperada numa avaliação de alunos de ensino superior em fase de conclusão do curso.

Ainda ligadas às posições enunciativas assumidas no discurso, algumas respostas apresentaram alterações no tema e também nos parágrafos escritos pela menina. Verificamos isso, por exemplo, em:

Exemplo 7. A morte de um caranguejo gigante e assustador.

Um caranguejo gigante e misterioso é surpreendido, ao mesmo tempo, por uma família; Débora, o seu marido e o irmão do marido. O caranguejo é muito perigoso, e destruidor. O caranguejo some com o barco da família misteriosamente e, mais adiante, é morto pelos homens (parentescos).

Por conseguinte, o esposo desmaia, sem poder alcançar a ajuda do irmão, provavelmente, por susto.

Logo, obtemos o seguinte, como resultado: as aventuras assustadoras vividas pela família, a emoção de encarar um imprevisto inesperado e aterrorizador e finalmente, a morte e superação dos obstáculos proposto. (resposta 50) 
Nessa resposta, verifica-se, logo de início, a alteração do título utilizado pela menina, tarefa associada com a reescrita de uma história sem respeitar seu conteúdo temático, já que foram feitas muitas mudanças. Além disso, esse formando omite o tema central (o passeio em família) e ações correlatas, como a da perseguição dos bezerros, e atribui a culpa do sumiço do barco ao caranguejo, afirmando ser este animal muito perigoso.

Podemos, portanto, afirmar que, nessas respostas, encontram-se os papéis assumidos pelos formandos para si ao imaginarem que a autora do texto pudesse ser uma aluna com quem eles atuariam enquanto professores. Tudo leva a crer que, numa situação concreta, eles procurariam manter as mesmas práticas vivenciadas durante sua escolaridade. Esses papéis assumidos revelam um contrato fiduciário (Greimas, apud Barros, 2002) pautado na tentativa de fazer a menina crer que uma alteração em situações da história poderia torná-la mais bem produzida, apontamento muito comum nas correções realizadas por professores em textos de seus alunos. Ao mesmo tempo, essa alteração realizada no texto-base revela que esses formandos não estavam aptos a atender à solicitação da questão: encontrar e propor soluções aos problemas nos elos coesivos da narrativa "O outro lado da ilha". Assim, enquanto modificavam o texto da menina tentando fazer crer ao examinador que esta seria a tarefa deles como futuros professores, acabavam por se distanciar do solicitado na questão.

Ainda ligadas às posições enunciativas assumidas no discurso, há respostas que não alteram o tema central, mas acrescentam certos detalhes ao texto - por vezes incoerentes em relação à produção da menina - numa tentativa de responder à questão proposta, mesmo sem a demonstração dos saberes acadêmicos indicados para a atividade. Isso ocorre em:

Exemplo 8. "Quando a fámilia foi dormir percebeu que os bezerros começaram a correr pelo quintal, logo a família foi ver o que estava assustando os bezerros. Quando de repente, com uma patada só um caranguejo gigante os atacou. Débora que era a esposa começou a chorar dizendo que queria ir embora.

A $1^{\circ}$ solução é a substituição do pronome "ele"ou a exclusão. No texto o pronome foi substituído pela palavra "família" dando mais objetividade.

A $2^{\circ}$ solução é a ligação através da conjunção "logo", desta forma a alteração indicará seqüência dos fatos.

A $3^{\circ}$ solução é a substituição do pronome "sua" pelo artigo "a" definindo a relação de Débora com a família. (resposta 21)

Nesse exemplo, foram modificados somente alguns pontos do texto da menina, muito embora certa mudança tenha afetado a coerência do texto: a inclusão de um quintal, por exemplo, transforma o aspecto rústico da ilha em uma simples passagem rural, fato que, ao 
propor a indistinção entre zona rural e região não explorada, pode constituir-se em um indício sobre o enunciador, provavelmente um certo tipo de enunciador urbano.

No exemplo seguinte, verificamos uma situação um pouco diferente:

Exemplo 9. História ocorrida na França, por volta do ano de 1992, quando uma família de classe média resolveu passar as férias de final de ano numa ilha.

Antes de conhecer o lugar, começaram a explorar a ilha e com isso explodiram uma barreira existente no lugar que servia de proteção para os habitantes da ilha.

Quando caiu a noite, os animais correndo assustados, chamaram a atenção dos visitantes, que lembraram que havia tirado a barreira de proteção. (resposta 129)

Nessa resposta, o formando sugere que a história tivesse ocorrido na França, em 1992, nas férias de final de ano. Com esses acréscimos feitos no texto, não houve qualquer proximidade com o que estava sendo solicitado na prova (cena genérica) como também com os papéis de professor/ aluno prestes a se formar em Letras, propostos na cenografia.

No exemplo seguinte, também existe o acréscimo de informações:

Exemplo 10. Logo chegou as férias a família Freitas foram viajar para uma ilha. Quando eles chegam lá foram logo explorando a ilha e explodiram uma barreira que os impediram de passar para o outro lado.

A noite logo após eles terem se recolhido, perceberam que um barulho estranho havia lá fora, quando foram ver o que estava acontecendo surpreenderam-se com um enorme caranguejo gigante que atacou-os. Débora assustada começou a chorar. Freitas imediatamente assustou o bicho.

Quando amanheceu eles foram até a margem do rio para ver como estava o barco, mas o barco não estava lá.

Voltaram para cabana e fizeram fogueira para serem identificados com a fumaça e voltarem logo para casa. (resposta 265)

Com o acréscimo do nome da família e a continuidade dada à história, além de o formando não ter realizado o que sugeria a questão, ele também esteve mais preso ao que se encontrava presente na cena englobante.

Além de alterarem a apresentação das situações expostas no texto, essas respostas (exemplos 9 e 10) revelam certa confusão entre parágrafo e frase, paradoxalmente como efeito do alto grau de escolarização de seus produtores. As frases por nós sublinhadas, embora pudessem ser vistas como exceções, confirmam essa afirmação. Por serem extremamente curtas, puderam ser apresentadas no mesmo parágrafo da frase anterior, mas períodos mais longos são considerados correspondentes a um parágrafo.

Por causa da alteração proposta ao texto, a resposta que se segue apresenta uma história com uma viagem totalmente diferente da que é narrada pela menina. 


\section{Exemplo 11. A viagem}

Em uma manhã de domingo a família do Senhor Osvaldo se prepara para fazer uma viagem.

Se preparam para conhecer a cidade de Ouro Preto.

É uma família muito alegre e unida, um ajuda ao outro a se vestir e não esquecer nada que esteja programada para a viagem.

Em poucos minutos estão todos sentados no ônibus com destino ao estado de Minas Gerais. Dentro do transporte canta e ouvem música. Após algumas horas param de cantar e ficam encantos com a paisagem que estão vendo, a visão que tem da cidade com muitos morros e várias igrejas com decorações feitas a mão e confeccionadas com ouro no século XVII.

A viagem foi linda e toda a família ficou encantada. (resposta 141)

A ilha, nessa resposta, foi trocada pela cidade de Ouro Preto, onde teriam ocorrido fatos completamente diferentes dos que estavam no texto da menina. Provavelmente, o formando considerava esta história criada mais bem elaborada que a da menina, o que revela que, se ele estivesse seguindo a cenografia, imporia a sua aluna uma história diferente daquela produzida pela aluna, provavelmente como mais adequada, mais correta.. No entanto, essa produção pode também indicar que este formando, sabendo estar despreparado para responder adequadamente à questão do Provão, recorre ao que estava mais próximo do que costumava fazer em suas práticas discursivas escolares.

Outra prática comum na escola vem reproduzida na resposta a seguir:

Exemplo 12. Quando estou em lugar desconhecido a primeira coisa que faço e conhecer o lugar, verificar se o mesmo está limpo e se não existe alguma animal ou insento que me causará estranheza.

Percebi que no lugar havia bezerros, caranguejo passeando na ilha fui atrás de uma pessoa para prendê-los, pois esses animais remete-me medo. Os bezerreros consiguimos dete-los mais o problema maior era de comum acabar com aqueles caranguejos. Foi um trabalho muito árduo, mas não adiantava chorar e querer fugir do problema, enfrentamos-o e resolvemos que maneira que não atraisse alarido.(resposta 49)

Com a mudança de foco narrativo e a alteração da narrativa, esse formando criou uma situação também distinta da apresentada pela menina, além de não ter realizado nenhuma alteração nos elos coesivos do texto "O outro lado da ilha", até porque ele não existe mais nessa resposta em virtude do número/tipo de alterações que foram realizadas. Também houve mudança de foco narrativo em:

Exemplo 13. Eu e minha família fomos passear em uma ilha, chegando resolveram conhecer a ilha. No meio do caminho tinha uma barreira na passagem, então eles tiveram que explodi-lá.

Logo ao anoitecer, foram dormir, mas não conseguem, porque o barulho era insuportável. Resolveram então levantar e vê o que estava acontecendo, viram os bezerros assustados, por causa dos carangueijos que queria atacá-los.

O marido de Débora e o seu irmão conseguiram pegar o carangueijo e levá-lo para um lugar distante onde pudessem apresentar perigo. Depois do problema resolvido enfim conseguiram dormir. (resposta 192) 
No exemplo [13], diferentemente do anterior, o formando não conseguiu manter o foco narrativo, apresentando o pronome pessoal de primeira pessoa somente no início da primeira frase, passando a utilizar alguns de $3^{\text {a }}$ pessoa no restante do texto produzido. Apesar de ter modificado o texto da menina, esse formando tentou corrigir o "problema" dos elos coesivos a que a questão fazia referência, mas também procurou terminar o texto apresentado. Embora houvesse a tentativa de "arrumar" o problema apontado, não houve qualquer justificativa para as alterações realizadas.

Embora haja a presença da primeira pessoa nos dois casos [12 e 13], do ponto de vista discursivo, em função dos papéis dominantes do quadro cênico, há um esmaecimento do sujeito, revelando certa distância do que estava indicado na cenografia, ou seja, que houvesse a tomada do lugar de professor ou de aluno de ensino superior, conforme a "escolha" feita pelo formando em relação a como responderia à questão.

Houve ainda algumas respostas que se limitaram a simplesmente continuar o texto produzido pela menina, também ignorando a solicitação de correção dos problemas dos elos coesivos no segundo parágrafo. Seguem alguns exemplos, os quais serão comentados no final da série (depois do exemplo 18):

Exemplo 14. "Qdo amanheceu eles foram ver como estava o barco, p/ir embora e perceberam que o barco não estava lá. Então sairam de novo p/explorar a ilha, e no meio do caminho encontraram um caranguejo que estava no penhasco. O marido de Débora, desmaiou e seu irmão não tinha como ajudálo, por isso foi chamar ajuda. Eles não quiseram saber e atiraram no caranguejo que caiu ribanceira abaixo.

Fiz uma inversão de frases de modo a dar um sentido contínuo no texto e achescentei um palavra ( Então) como forma de ligação entre as frases e para desfazer a infusão com o primério parágrafo. (resposta 16)

Exemplo 15. Quando amanheceu eles foram ver como estava o barco irem embora e perceberam que o barco não estava lá, então saíram para explorar a ilha(...). ajuda(...).

O marido de Débora desmaiou e seu irmão não tinha como ajudá-lo e por isso foi chamar

*irem $=$ verbo concordando com o sujeito

*então = conectivo entre uma frase e a outra

* foi feito um novo parágrafo (O marido de Débora) porque é um outro acontecimento, não tem relação com a frase anterior. (resposta 43)

Exemplo 16. "Quando amanheceu, o barco não encontrava-se no lugar que a família o deixara. Foi encontrado um caranguejo em um penhasco e a família o empurrou ribanceira abaixo. O marido de Débora desmaiou e a família foi procurar ajuda na ilha".

A escritora deveria descrever as personagens ou ao menos os nomes dos componentes da família; a retirada dos pronomes pessoais (eles) contribuiria a um melhor entendimento da redação; a explicação da última frase poderia aumentar a capacidade de entendimento do leitor. (resposta 46) 
Exemplo 17. Quando amanheceu, foram ver como estava o barco para partirem. Notaram que o barco não estava lá. Os homens sairam para explorar a ilha. No meio do caminho, encontraram um caranguejo que estava no penhasco. Eles não quiseram saber, atiraram no bicho. Este caiu ribanceira abaixo. Contudo, o marido de Débora, desmaiou e seu irmão não tinha como ajudá-lo, por isso foi pedir ajuda.

Soluções:

$1^{\text {a }}$ Adotar períodos curtos, facilitando a compreensão do texto

$2^{\circ}$ evitar redundâncias( o que pode ser viabilizado pela utilização de vírgulas)

$3^{\circ}$ Escolha lexical.(optar por sinônimos, evitando repetições de palavras e efeitos cacafônicos). (resposta 113)

Exemplo 18. O irmão de Debora foi buscar ajuda porque com o tamanho do caranguejo seu cunhado desmaiou e não conseguindo carrega-lo, porque com o tamanho do caranguejo correu e machucou o pé na pedra e estava com dificuldade para andar; mas ele conseguiu arrastar o seu cunhado para um canto até chegar ajuda. Depois de um certo tempo encontrou os outros e foram até o férido.

E com a ajuda de todos seu cunhado ou seja o marido de Debora voltou em si com alguns remédios que levaram para emergência. E logo em seguida começaram à procura do barco que havia sumido, quando derrepente avistaram deduziram com a força do mar a corda rebentou levando o barco para longe. A sorte que Debora é uma campeã de natação é foi até o barco e o trouxe de volta e todos foram embora muito felizes, porque estava saindo da ilha assustadora. (resposta 140)

Esses exemplos permitem afirmar que muitos formandos recorreram à sua memória e reproduziram uma prática escolar bastante comum: a continuação de narrativas. No que se refere às cenas, voltaram-se mais para a cena englobante, conforme já foi exposto.

Todos os exemplos apresentados neste capítulo (exceto o exemplo 4) remetem-nos a uma postura impositiva que muitas vezes é vista nas escolas. Ao corrigirem textos de seus alunos, alguns professores alteram completamente a estrutura e, sobretudo, o sentido do que foi produzido. Não é respeitada a autoria do produtor do texto e a maior parte das alterações fica mais no âmbito do estilo do autor do que no aspecto da clareza ou da estrutura do texto.

Fixados no quadro cênico, todas as respostas apresentadas fazem-nos afirmar que, embora esses formandos assumam - no plano do enunciado - o papel de professores, tal como acreditam que este possa ser, eles mantêm, na verdade, a atenção voltada para a demonstração de saberes que eles consideram pertinentes à solicitação da questão e adequados ao que imaginam estar mais próximo do esperado pela banca examinadora do Provão. Estavam diante de uma situação complexa: ao assumirem papel de professores de uma menina, procuravam também, enquanto alunos, dar testemunho do conhecimento que consideravam pertinente para a situação de avaliação em que estavam envolvidos. No entanto, estavam bem distantes dessa possibilidade, já que reproduziram apenas uma prática escolar diferente da que deveriam demonstrar: um saber acadêmico desenvolvido no ensino superior. 
Muitas respostas revelaram-se como atividades escolares voltadas para a alteração de detalhes ou a continuidade do texto da menina sem que fosse feito algo similar ao que solicitava a questão. Isso ocorre em 47 respostas, ou seja, em 16,3\% do total de respostas com que trabalhamos.

Voltando-se mais à cena englobante, ou seja, ao que consideravam adequado para responder a uma atividade semelhante às atividades escolares já conhecidas, dois desses formandos indicaram o que poderia ser feito pela família para resolver o problema enfrentado na ilha e não os problemas dos elos coesivos no texto. Isso ocorreu em:

Exemplo 19. Quando foram dormir poderiam ter vasculhado o local onde estava os bezerros, outra solução era pegar os bezerros e colocar no outro lado da ilha e depois pegar sua familia e sair imediatamente daquele local. (resposta 15)

Exemplo 20. Débora a esposa ao invés de ficar chorando dizendo que ia embora, deveria ter colocado primeiro os bezerros em seus respectivos lugares para dormir. Quando os próprios estivessem abrigados, então a família se acomodaria em seu alojamento e nada disso aconteceria. Se os próprios da família tivessem se organizado como deveriam todos dormiram em paz. (resposta 32)

Tendo se referido ao que a família deveria ter feito diante da situação vivenciada na ilha, esses formandos trouxeram às suas respostas um diálogo com a experiência apresentada nessa narrativa. Tiveram uma atitude responsiva no âmbito da práxis representada no texto " $\mathrm{O}$ outro lado da ilha", atitude esta que lhes serviu para não deixar em branco o espaço destinado à resposta a uma questão a que eles não sabiam responder. Estavam fora do quadro cênico, não seguindo nem o discurso escolar, nem o que seria esperado para uma prova.

Diante do exposto nos exemplos [4] a [20], podemos concluir que, ao se prenderem mais ao que previam como cena englobante, ou seja, ao discurso escolar, alguns formandos demonstraram-se despreparados para atender à solicitação da questão. Outros, que se ocuparam mais de procurar atender ao que estava indicado na cena genérica e na cenografia, estiveram mais próximos de demonstrarem seus saberes, de acordo com o que foi proposto a eles.

Ao solicitar que o aluno propusesse "três soluções para o problema dos elos coesivos", a questão indicava que essas soluções deveriam ser justificadas "com o apoio de noções lingüísticas”. Assim, tudo o que os formandos leram ou ouviram a respeito de texto e de coesão textual foi observado em suas respostas, mesmo que não se pudesse verificar, em suas afirmações e/ou justificativas, noções lingüísticas geralmente discutidas no curso de graduação em Letras. 
Como o papel dos formandos era o de demonstrar amplo conhecimento lingüístico, surgem, em alguns casos, citações e comentários de fontes tidas como insuspeitas (NGB) ou de autores e conceitos considerados pertinentes à solicitação da questão:

Exemplo 21. De acordo com a (NGB) Norma dita "culta", o resultado seria:

Quando eles foram dormir, perceberam que os bezerros começaram a correr e viram o que os, estava assustando. De repente, com uma patada só um caranguejo gigante os atacou. Débora, que era esposa do atingido, começou a chorar dizendo que queria ir embora.

Para compreensão do texto, totalmente gramaticalmente (Chomsky), basta compreender que os anacolutos, repetições e redundâncias, marcas da oralidade (retiradas na construção acima) foram comumente utilizados - o que é de se esperar de uma menina de dez anos - em sua redação. A coesão, por outro lado, advém no texto infantil sem noção bem clara do que se concebe "sistema déiticoanafórico"(Fiorim). Na retificação proposta os adjuntos adverbiais de tempo \# apresentados pela garota no primeiro período foram substituídos por uma oração coordenada (ver) à principal (perceber) da temporal (ir). A conjunção quando, desnecessária e redundante, foi também excluída do segundo período.

O único problema grave foi resolver a ambigüidade do pronome possessivo "sua" do único período, aparentemente referente de "caranguejo", no entanto referindo-se ao protagonista.(resposta 67 - grifo nosso)

O formando busca como justificativa para as alterações propostas a NGB, Chomsky e Fiorim, indicando como conteúdos associados a esses autores palavras referentes às suas propostas, porém distantes de seus estudos propriamente ditos, o que nos sugere que ele tenha feito uma leitura superficial desses tópicos apresentados, diferente do que ocorre em:

Exemplo 22. Para melhor fluência na linguagem escrita, é necessário coesão perfeita, pois facilita a coerência. Desse modo, o leitor pode compreender a mensagem com o mínimo de esforço e \# evita-se a quebra da máxima de quantidade de Grice (falar o necessário). Na reescritura do segundo parágrafo, uma possibilidade é a retirada das repetições "quando eles" porque já está sub-entendido que as ações giram ao redor da família. Outra possibilidade é a substituição da segunda menção de "os bezerros" por um dêitico ("os") a ser colocado antes do verbo. Também será necessária a transformação do\# "os" que precede "atacou" por "a família", cujo lugar seria depois do verbo. A terceira mudança seria aclarar de quem Débora era esposa, já que "sua" pede a clareza de "posse" e, no texto, um leitor distraído pode achar que é do caranguejo... Em outras palavras, sugiro a seguinte reescritura:

"Quando eles foram dormir, perceberam que os bezerros começaram a correr e foram ver o\# que os estava assustando. De repente, com uma patada só, um caranguejo gigante atacou a família. Débora, que era a esposa, começou a chorar dizendo quie queria ir embora" (resposta 68-grifo nosso)

Esse formando, ao citar Grice, consegue associá-lo, de passagem, ao que ele realmente propõe. Já, em [23], aparece uma referência a Saussure:

Exemplo 23. Ao anoitecer, notaram que os bezerros corriam rapidamente. Assustaram-se - Foram atacados por um caranguejo gigante. Débora, chorando muito, pede para irem embora dáquele lugar. Justificativa $\rightarrow$ Segundo Saussure, o significado e o significante tem que haver um significado, uma representação. Neste, segundo parágrafo, não há clareza dos acontecimentos, não tendo nem sequência dos fatos. 
Ocorrem problemas com os sintagmas, faltando objetividade. (resposta 132- grifo nosso)

Apesar de haver referência ao signo lingüístico, não é feita qualquer relação entre este conceito e o conteúdo solicitado na questão, até porque realmente não há relação entre eles. É como se o formando, ao ter que justificar seu trabalho com seus conhecimentos lingüísticos, só se lembrasse desse autor que certamente é apresentado em todo e qualquer curso de Letras.

O exemplo [24] traz a indicação de uma autora conceituada na área de coesão textual:

Exemplo 24. Uma família vai passar as férias em uma ilha. Ao chegar é preciso explodir uma barreira que os impedem de passar.

Quando chegaram à ilha, viram que havia bezerros e caranguejos gigantes. Após se acomodaram, foram dormir.

Durante à noite, ouviram os bezerros correndo e foram verificar o que estava acontecendo. De repente viram caranguejos gigantes atacando os animais. Débora ficou apavorada, começou a chorar dizendo que queria partir da ilha.

Três soluções: uso de elementos coesivos, coerentes e concordância. Eliminação dos pronomes excedentes, pois em alguns casos são elementos vazios (elipse "Ingedore"em coesão lexical) e os mesmos são recuperados através dos verbos. Mas tudo isso não é caracterizado "erro", pois o texto foi produzido por uma criança de apenas dez anos. (resposta 138- grifo nosso)

A breve proposta de se usar a elipse no texto pode realmente ser associada aos estudos de coesão textual realizado pela autora citada. Não ocorre o mesmo em:

Exemplo 25. Notamos que o texto o "O outro lado da ilha" é cheio de repetições, mal elaborado. O pronome lhe teve várias repetições, devido a autora ter pouco domínio da gramática. Pois a gramática é de cunho filosófico, A língua é dinâmica e sofre suas transformações. Segundo Celso Pedro Luft, ele defende totalmente a idéia de que a gramática tradicional ainda é a melhor forma de ensinar na produção de textos. E mostrar que o problema não está na gramática, mas nos educadores da língua. Enfatizando em algumas passagens do texto a preposição lhe foi aceitável. (resposta 267-grifo nosso)

O formando, ao fazer referência à necessidade da gramática normativa para a aprendizagem da produção de textos, associa essa indicação ao autor Celso Pedro Luft, que não propôs exatamente essa associação.

Nota-se, portanto, que, na tentativa de revelar o conhecimento lingüístico sob avaliação, esses formandos consideraram mais importante, nos exemplos apresentados, indicar o nome do autor - uma forma de heterogeneidade mostrada - do que explicitar os conceitos por ele desenvolvidos. Ao citar determinado nome, o formando imagina poder fazer crer que domina o conhecimento lingüístico proposto por esse autor tanto quanto o examinador. Assim, a resposta dada estaria mais próxima do esperado. 
Foucault (1971), ao comentar a vontade de verdade presente na ordem do discurso, afirma que o ponto central da relação saber/poder encontra-se na busca da verdade como conhecimento absoluto. Nesses exemplos em que aparece a heterogeneidade mostrada, há um combate "pela verdade" travado entre os formandos e os examinadores, no qual os primeiros tomam emprestadas as armas dos segundos para se alçarem a uma posição em que essa disputa seja possível. Mesmo imaginando que os examinadores estejam mais próximos da verdade por causa do poder que a situação lhes confere, os formandos também querem conquistar a verdade ao demonstrar seus conhecimentos acadêmicos, no caso apoiados em autores ou noções lingüísticas.

Remetendo-nos às formações imaginárias propostas por Pêcheux (AAD-69), podemos afirmar que, ao procurar mostrar indícios de seu conhecimento, o formando faz a imagem de seu interlocutor como a de alguém que conhece esses nomes e/ou conceitos e que imagina ser necessário esse conhecimento para uma boa avaliação. Por outro lado, a imagem que faz do “ideal” de formando em Letras, modelo que ele considera esperado pelo examinador, é a de alguém apto a discursar acerca desses temas e que precisa demonstrar certo conhecimento na avaliação. Esses formandos tinham como imagens atribuídas a si mesmos a de sujeitos que deveriam, de qualquer forma, provar seu conhecimento, mesmo que não conseguissem fazê-lo de maneira satisfatória. Estavam presos à cena genérica, ao que imaginavam adequado para ser feito numa prova como essa: citar autores e fazer referência aos conceitos propostos por eles.

Para demonstrar ao examinador a imagem de detentor do conhecimento considerado satisfatório, o formando também recorre a afirmações categóricas que produzem um ethos de certeza, vinculado às coerções genéricas depreensíveis do contexto de uma prova. Ele joga com a expectativa de que o examinador tenha conhecimento, clareza, do que está perguntando e isso é demonstrado pela maneira como se direciona a questão ao formando: "Uma característica desse texto $\underline{e}$ a forma como a menina faz as ligações coesivas". Esse enunciado faz o formando, na posição de leitor, crer que o avaliador, na posição de autor, domina perfeitamente esse tópico (coesão textual). Sendo assim, caberia ao formando demonstrar tudo o que aprendeu na faculdade a respeito desse tema, seguindo as ordens do enunciador: "elabore um texto", "proponha alterações", "apresentando três soluções”, “justifique”. É dessa maneira que o avaliador incita o formando a responder.

Sendo essa uma das questões de uma avaliação institucional, os formandos deveriam respondê-la procurando revelar todo conhecimento lingüístico construído durante os anos em que se prepararam para tornarem-se professores, indicando também o ethos da certeza 
presente na elaboração da questão. A questão do ethos está ligada, naturalmente, à situação do discurso, no caso, uma prova. Nessa situação, não é conveniente demonstrar dúvidas ou pouco conhecimento acerca do assunto avaliado. Eis algumas outras respostas de formandos que evidenciaram a tentativa de reproduzir esse ethos, as quais serão comentadas ao final da série (depois do exemplo [29]).

Exemplo 26. A primeira solução consiste em referenciar previamente, neste mesmo parágrafo ou no anterior, os elementos lingüísticos que aparecem no texto, como os bezerros e sua esposa, sem antecedentes lógicos.

A segunda solução seria eliminar do texto ( $2^{\circ}$ parágrafo) a conjunção adverbial temporal "quando"que aparece sem coesão, nos dois exemplos finais do parágrafo.

A terceira solução visa combinar as duas anteriores, adequando a introdução de elementos lingüísticos à presença de um antecedente lógico, ou tornando-os indefinidos (uns bezerros, por exemplo) ou eliminando-os completamente (que era sua esposa), além de reordenar as frases evitando começá-las sempre pela mesma conjunção adverbial temporal ("quando") num jogo indefinido e recorrente de anáforas típicas de um discurso verbal ainda não pautado inteiramente pelo controle racional do texto escrito. (resposta 8 - grifos nossos)

Exemplo 27. Ao se analisar o segundo parágrafo, a característica predominante é a oralidade, além de conter falhas em termos de aspectos da língua e inúmeras repetições desnecessárias. Assim sendo, para adaptar o texto à linguagem escrita, é possível reescrevê-lo da seguinte forma:

"Ao irem dormir, perceberam que os bezerros começaram a correr e foram ver o que estava assustando os animais. De repente, com uma patada só, um caranguejo gigante os atacou. Débora, a esposa, começou a chorar dizendo que queria ir embora."

Diante das alterações, faz-se necessário explicar os motivos, a saber:

1-a repetição da palavra "bezerro" foi eliminada;

2-a primeira frase foi organizadas, posto que as idéias foram lançadas, mas sem uma organização lógica.

3-o mesmo aplica-se para a frase seguinte: talvez a menina quisesse dizer: "Quando eles de repente foram atacados por um caranguejo". No entanto, também se lembrou que foi com uma patada.

4-em relação à última frase, a saber, "Débora que era sua esposa...", não é possível descobrir de quem ela era esposa, posto que o marido não foi mencionado anteriormente, sendo, portanto, a exclusão do pronome possessivo adequada. (resposta 85 - grifos nossos)

Exemplo 28. Os elementos de ligação interna do texto estão mal posicionados como por exemplo, o uso das vírgulas, das conjunções, o pleonasmo e outras traços próprios da linguagem oral de crianças nesta fase. Este conjunto, além da falta de coesão, causa também como conseqüência a incoerência, pois tais construções interferem diretamente uma sobre a outra, digo, interferem diretamente na inteligibilidade do texto, seria mais proveitoso que o professor como mediador, fosse lentamente, porém gradativamente adaptando o aluno (no caso a menina) ao uso correto das formas por meio da língua oral (a padrão) inicialmente fazendo-o perceber como fazemos tais ligações de modo natural e espontâneo, como por exemplo a tomada de termo, quando fazemos isso não repetimos pleonasticamente; ou invocamos sistematicamente a pessoa do discurso. Após perceberem estas funções que fazemos naturalmente e usamos, seria aconselhavel aplicar o pronome de reescrita de seu próprio texto corrigindo as possíveis inadequações e escolhendo dentro de um campo semântico as palavras a serem utilizadas. (resposta 172 - grifos nossos)

Exemplo 29. Percebemos que no texto, além de problemas de coesão, temos também os de coerência. Temos repetições desnecessárias que tornam o texto redundante, e podemos justifica-lo por se tratar de uma produção de uma criança de 10 anos que utiliza muito a forma como ela fala ao 
escrever. $\mathrm{Na} 1^{\mathrm{a}}$ sentença, não há necessidade da repetição do pronome eles, a elipse tornaria o texto mais coeso. Na continuação, eliminaríamos "que quando eles" utilizariamos apenas "e" conjunção aditiva que ligaria as duas sentenças dando sentido adequado às mesmas. Na próxima oração começaríamos por "De repente que criaria uma expectativa no leitor, eliminaríamos "quando" desnecessário, e eles, pois "os" atacou "já nos remete à eles anaforicamente. Porém a última oração, não é coerente pois não sabemos de quem Débora era esposa. (resposta 206 - grifos nossos)

Nesses quatro exemplos, verifica-se, principalmente, em virtude da escolha lexical, a tentativa de demonstrar um discurso técnico, tanto do ponto de vista lingüístico como do ponto de vista pedagógico. Ao responder à questão dessa maneira, os formandos parecem querer atender à expectativa dos examinadores, revelando domínio do repertório teórico esperado para um concluinte do curso de Letras. Procurando provocar esse efeito da certeza, aproximam-se do que poderia ser considerada uma resposta aceitável, o que mostra que a certeza que pretendiam demonstrar estava aliada a seus saberes acadêmicos, ao modo como eles se sentiam em relação ao conteúdo da questão.

Nota-se também, nos exemplos [28] e [29], o uso da primeira pessoa do plural (cf. verbos sublinhados) como uma tentativa de demonstrar esse "nós" inclusivo como eu (formando) e você (examinador) ou também como eu (formando) e os sujeitos que têm esse mesmo conhecimento lingüístico, mas nunca correspondendo a "eu" (formando) e "você" (autora do texto-base). Com esse recurso, o formando procura neutralizar as diferenças impostas pela cena genérica.

Conforme verificamos, ao lado de formandos presos à situação de prova (cena genérica), imaginando-se alunos sendo avaliados em um exame do ensino superior, há outros, mais presos à cenografia, reportando-se ao texto da menina como se fossem professores dela. Em nosso corpus, as respostas dividem-se da seguinte forma:

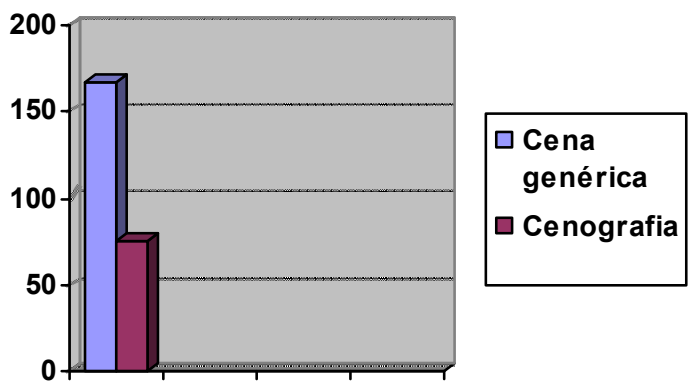

Foram 167 respostas nas quais os formandos estiveram mais ocupados com a cena genérica e 76 mais voltadas à cenografia proposta. Não poderia haver qualquer relação entre essa "opção" e a adequação da resposta, uma vez que existem respostas pertencentes aos dois grupos que revelam boa reflexão acerca do tema proposto. 
As demais respostas dividem-se entre aquelas mais voltadas à cena englobante e as que se distanciaram do quadro cênico (como observamos nos exemplos [19] e [20]). Nenhuma delas atendia ao que era solicitado, pois ou o formando colocava-se no lugar de aluno de ensino fundamental e médio, ou de alguém que poderia fornecer indicações à família de como resolver os problemas enfrentados em suas férias na ilha.

Por outro lado, vale afirmar, também, que o poder legitimado da instituição não é marcado somente no contexto imediato, conforme já foi mencionado, mas também na veiculação, pela Internet, de uma indicação de resposta esperada, sugerindo que o afastamento desse gabarito poderia ser visto como erro.

O gabarito indicado pelo $\mathrm{MEC}^{23}$

\section{$1^{\mathrm{a}}$ Parte:}

Identificar os problemas coesivos do 2o parágrafo e propor soluções. São eles:

1. falta de explicitação do antecedente para "eles" (já usado no 1o parágrafo também sem explicitação do antecedente);

2. falta de explicitação do antecedente de "sua" ("sua esposa");

3. repetição de "eles";

4. uso de "e que quando";

5. repetição de "os bezerros";

6. uso do artigo definido em "os bezerros" (na primeira vez em que aparece).

\section{Soluções possíveis:}

1. mencionar um antecedente possível para "eles", que poderia ser: "pai, mãe e filhos"; "João, Débora e filhos", ou qualquer solução que seja apropriada para ser retomada por "eles";

2. o marido de Débora deve ser nomeado antes ou todo o trecho ("Débora que era sua esposa") precisa ser alterado;

3. a repetição de "eles" pode ser evitada pelo uso de elipse, sinonímia etc;

4. poderia permanecer apenas o "e" ou alterar toda a estrutura da frase;

5. para eliminar a repetição de "os bezerros", usa-se o pronome adequado;

6. usar artigo indefinido ou outra forma de introduzir informação nova.

\section{$2^{\text {a }}$ Parte:}

Justificar as soluções, usando noções lingüísticas.

23 MEC - Exame Nacional de Cursos - Letras: Grade de respostas. (2001). Disponível em: <http://www.INEP.gov.br/download/enc/2001/padrao resposta/PR2001 letras.pdf>. Acesso em 14 jul. 2005. 
1. as formas pronominais precisam estar ancoradas em antecedentes explícitos no texto (isso justifica a solução de 1 e 2);

2. repetições são típicas da oralidade. É característica da escrita o uso de diferentes recursos para fazer retomadas;

3. "que" e "quando" são conectivos que não tem função neste texto;

4. os artigos definidos são usados para retomar uma informação dada ou compartilhada.

Essa sugestão de resposta parece muito mais voltada à normativização da língua do que à visão do texto como processo com múltiplas possibilidades de atribuição de sentidos.

Sabemos que o texto dado para ser corrigido no exame era apenas um fragmento do que fora apresentado por Marcuschi (2000b) para a exemplificação da anáfora indireta. Neste gabarito, ignorou-se, porém, essa noção. Algumas anáforas foram mostradas como erros, não tendo sido consideradas como possibilidades naturais presentes nos discursos, não interferindo negativatimente na coesão nem na atribuição de sentidos ao texto. É certo que não se supunha que os formandos tivessem realizado a leitura do texto de Marcuschi (2000b), nem que a única possibilidade de resposta seria a consideração das anáforas indiretas, mas também não se deveria ignorá-las ou até mesmo considerá-las inadequadas. Com isso, não estamos considerando que o tópico da questão deveria ser esse, mas que isso não poderia ser totalmente desprezado porque se torna contraditório à própria fonte pesquisada para a elaboração da questão.

Evidentemente, existem problemas de coesão textual na produção desse texto produzido pela menina, mas estes não surgem apenas da falta de "retomada" de informações anteriores. Surgem também em virtude da sobreposição de orações subordinadas desvinculadas de uma oração principal, tendo sido este o recurso utilizado pela menina para garantir maior suspense para seu texto, além de não haver continuidade entre a primeira e a segunda frase do parágrafo a ser alterado, o que faz o texto parecer "truncado", sem coesão. Esses problemas realmente existem e podem ser corrigidos com uma maior estruturação dos parágrafos, porém não podemos afirmar que a falta de coesão ocorre em virtude do uso das anáforas indiretas.

Outra afirmação a ser questionada é a segunda justificativa apresentada para a solução, na qual se indica que as repetições devem ser eliminadas e que não "típicas da oralidade". Essa separação do que é tipicamente oral e tipicamente escrito desconsidera que essas duas modalidades lingüísticas estão intrinsecamente ligadas e não podem ser dicotomizadas, sem o risco de se recair na "grande divisa", situação criticada por Street e, segundo o autor, 
responsável pela consideração de que a escrita seria uma tecnologia superior e mais complexa que a oralidade.

Essa concepção do Provão reflete os princípios da pedagogia tecnicista, bastante divulgados na década de 70 do século XX, que defendiam padrões de racionalidade, eficiência e redução de gastos. Se associarmos essa concepção de avaliação ao ensino de línguas, veremos que o parâmetro seguido é o do certo/errado, com base nos princípios da gramática normativa. Assim, acredita avaliar com segurança, com objetividade, pois haveria um conhecimento correto, homogêneo e universal a ser aprendido. Subjacente a esse procedimento está uma concepção de língua como instrumento de comunicação, formado por um sistema de signos, organizados em níveis hierárquicos (fonológico, morfológico e sintático). Enfim, vê-se a língua apenas como estruturas lingüísticas, as quais o aluno deve reproduzir ao ser avaliado.

No Provão, a educação é colocada como um produto a ser avaliado, com vistas a uma melhoria na qualidade de ensino e seus reflexos na área econômica. Assim, fica evidenciado o caráter centralizador do Estado na condução desse exame, destacando-se os aspectos normativos e de simples fiscalização de desempenho, sem se verificar a análise dos dados obtidos com a finalidade de se propor um plano de ação para dar conta de eventuais problemas que ocasionem a falta de qualidade nos cursos avaliados. 


\section{Capítulo II}

\section{Aspectos teóricos e metodológicos}

\section{Aspectos teóricos}

Ao estudarmos a leitura no contexto enunciativo do Provão, torna-se necessário apresentar a que referentes teóricos os dados encontrados serão submetidos, ou melhor, quais noções de discurso e de leitura norteiam este trabalho.

Inicialmente, gostaríamos de retomar o conceito de condições de produção, pois não se pode imaginar qualquer prática discursiva sem levar em consideração os processos sóciohistóricos constitutivos de todo discurso. Assim, tem-se de levar em consideração que os sentidos são regulados socialmente, de modo que a mesma expressão ou gesto produz sentidos diferentes, uma vez que o sentido não se depreende diretamente da materialidade lingüística, mas de uma série de relações que, a partir dela, são estabelecidas entre interlocutores e as condições de produção do discurso.

Em se tratando de condições de produção de leitura, por exemplo, temos uma gama bastante complexa de fatores que produzem sentidos aos textos lidos, sendo impossível percebê-los apenas como transmissores de mensagens. Ao ler um determinado texto, tem-se contato com aspectos sociais, históricos e inconscientes dos sujeitos envolvidos (autor e leitor) que podem ser depreendidos do próprio enunciado.

Completando essa noção de condições de produção de leitura, recorremos à proposição de Pêcheux (AAD-69) quanto à consideração das formações imaginárias, entendidas como antecipações das representações dos interlocutores (A e B). Segundo esse autor, o interlocutor A faz uma imagem do lugar que B ocupa, do lugar que B imagina ocupar, do lugar que ele mesmo (A) ocupa e também do lugar que B imagina para A. Esse jogo imaginário representa a tomada de um lugar social que os interlocutores fazem no processo discursivo. Assim, podemos considerar que, ao fazer uma antecipação das representações do leitor, o autor baseia-se na imagem que o leitor faria sobre o autor de tal texto, na imagem que o autor tem da imagem que o leitor faz de si mesmo e na imagem que o autor tem da imagem do leitor sobre o texto. Sem contar as respectivas imagens e antecipações sobre o referente do discurso. Do mesmo modo, o leitor formula, inconscientemente, para si as representações do 
autor no processo discursivo. Evidentemente, essas imagens determinam, em grande parte, a atribuição de sentidos ao texto lido.

Também no âmbito das condições de produção, consideramos para este trabalho, conforme já exposto no capítulo I, as cenas enunciativas propostas por Maingueneau (2004: 1998). Ao referir-se ao discurso como encenação, o autor não se referiu à "re-presentação de realidades, de conflitos (sociais, econômicos) dados antecipadamente" (Maingueneau, 1997:1987, p. 33), mas a elementos que se integram e dão forma ao discurso e aos sujeitos envolvidos no ato enunciativo. As cenas enunciativas, conforme vimos, dividem-se em: cena englobante (tipo de discurso), cena genérica (gênero do discurso) e cenografia (modo de constituição do discurso). Toda leitura traz à tona essas cenas com as quais autor e leitor também lidam para a atribuição de sentidos a seus discursos.

Aliadas a essas formações imaginárias e às cenas enunciativas, as condições de produção envolvem-se, também, com os esquecimentos propostos por Pêcheux (AAD-75) como fundadores de todo discurso. O esquecimento $n^{a} 1$, também chamado esquecimento ideológico, é da instância do inconsciente e refere-se à ilusão de sermos a origem do que dizemos, quando, na realidade, retomamos sentidos preexistentes. O esquecimento $n^{\circ} 2$ refere-se à ilusão que o sujeito tem de produzir, em seu discurso, o que realmente pensou, da maneira mais clara possível.

Esses dois esquecimentos são bastante significativos para que se possa pensar a leitura, pois indicam as ilusões que o autor tem ao produzir seu texto. Ao imaginar-se origem do discurso e transmissor de uma verdade facilmente depreendida do enunciado, o autor tem a ilusão de que o leitor atribuirá o mesmo sentido que foi imaginado para seu texto. São esses dois esquecimentos que o fazem agir dessa maneira, desconsiderando sua memória discursiva, uma vez que esta é da ordem do inconsciente.

Na memória discursiva dos autores e leitores, também se inserem as crenças acerca da leitura. Essas crenças, neste trabalho chamadas de concepções de leitura, foram construídas ao longo do tempo e se fixaram, em seus diferentes modos de circulação, como formas de atribuição de sentido ao texto. No presente trabalho, elas fazem parte dos aspectos metodológicos, que apresentaremos a seguir. 


\section{Aspectos metodológicos: as concepções de leitura}

Ao longo do tempo, a leitura foi percebida e ensinada de maneiras diferentes. Logicamente, conforme a maneira como ela é concebida, seu ensino também se torna diferente. Embora saibamos que o ensino da leitura não seja diretamente o tema deste trabalho, não desconsideramos sua relação com as crenças que se fazem/fizeram a seu respeito.

Apresentaremos, a seguir, as concepções de leitura que identificamos como mais significativas para o estabelecimento de critérios para a análise dos textos que compõem o corpus.

\section{a. Concepção tradicional}

Para a concepção tradicional, a leitura é tratada como mera decodificação, envolvendo o reconhecimento dos sinais gráficos da língua e podendo ser reduzida à conversão de grafemas nos fonemas correspondentes.

Essa habilidade de decodificação requer que o indivíduo seja capaz de realizar a associação letra/som de forma passiva, repetitiva. Sua tarefa seria a de juntar "peças" para buscar o sentido que o autor atribuiu à obra.

Assim:

"a concepção tradicional da leitura constituiria o que foi
definido como um modelo de processamento ascendente. Tal
modelo supõe que o leitor começará por fixar-se nos niveis
inferiores do texto (os sinais gráficos, as palavras) para formar
sucessivamente as diferentes unidades lingüísticas até chegar
aos níveis superiores da frase e do texto. Para seguir esse
processo, o leitor deve decifrar os signos, oralizá-los mesmo
que seja de forma subvocálica, ouvir-se pronunciando-os,
receber o significado de cada unidade (palavras, frases,
parágrafos, etc.) e uni-los uns aos outros para que sua soma lhe
ofereça o significado global" (COLOMER e CAMPS, 1996,
p.30).

Baseando-nos em Cavallo e Chartier (1998), podemos notar que essa concepção existe desde a Antigüidade, uma vez que os gregos e os romanos acreditavam que, para ler, seria necessária uma disciplina rígida e um método analítico caracterizado pelo progresso passo a passo: primeiro decorar o alfabeto; depois, soletrar; por fim, decodificar palavras isoladas, 
frases, até chegar a textos contínuos. Esse mesmo método era aplicado à aprendizagem da escrita.

Ainda hoje, observamos alunos que aprendem a ler de uma maneira semelhante, uma vez que encontramos essa concepção em nossa sociedade. Parte-se do pressuposto de que, indo da menor unidade para a maior, o aluno conseguirá, pouco a pouco, apropriar-se da leitura porque ela ainda é considerada por muitos apenas uma decodificação, uma simples soma de sinais gráficos, capaz de trazer à tona um sentido inquestionável.

Assim como na concepção tradicional, no behaviorismo, os indivíduos aprenderiam por hábitos gerados por situações de estímulo/resposta. A capacidade de ler seria, então, adquirida em função da formação de hábitos, sendo o sentido o resultado da soma linear das palavras numa frase.

Por mais antiga e contestada que seja a prática pedagógica decorrente dessa concepção, ainda hoje, observa-se, nas escolas, o mesmo método de alfabetização adotado pelos gregos e romanos durante a Antigüidade. Com isso, a leitura ainda é reduzida apenas ao aspecto gráfico e normativo que a constitui. Segundo Maingueneau (2004: 2001),

"Compreender um enunciado não é somente referir-se a uma gramática e a um dicionário, é mobilizar saberes muito diversos, fazer hipóteses, raciocinar, construindo um contexto que não é um dado preestabelecido e estável (p. 20).

Para além da concepção da escrita como um código, essa concepção assume a variedade codificada pela escrita como padrão de correção e de exclusão das formas lingüísticas concorrentes. As "marcas de oralidade" e as repetições são vistas como erros nessa concepção. Todo texto deveria recorrer às regras da gramática normativa, sem as quais não existiria possibilidade de compreensão. Pode-se, pois, concluir que, ao lado de uma concepção de sujeito como decodificador de sinais gráficos, há uma concepção de texto como armazenador de um sentido único e da língua como código. Sujeito e texto assim concebidos orientam para uma concepção de leitura como atribuição de um sentido único e inquestionável ao texto.

Selecionamos algumas respostas - apresentadas a seguir - em que se observa a referência à concepção tradicional de leitura.

Exemplo 30. Uma solução seria, primeiramente, retirar o segundo que parece na frase, fazendo com que haja uma coesão na medida em que se consegue estabelecer o elo entre causa (ouviram os bezerros correr) e consequência (foram ver). 
Feito isso, poder-se-ia retirar o pronome "eles" na frase: "Quando eles de repente...", fazendo com que a frase obtenha sentido. No final, substituindo-se o pronome possessivo "sua" pelo nome de algum personagens (da família) ou por uma definição, como "Débora, que era esposa de João" ou "Débora, a mãe das crianças", etc, eliminando-se a ambigüidade.(resposta 30- grifo nosso)

Esse formando acredita que, para que a frase tenha sentido é necessário retirar o pronome "eles". Em outras palavras, a frase em questão só se tornaria interpretável se tivesse todos os elementos explicitamente relacionados. Já observamos que essa afirmação é falsa. Ainda que se aceite que há um problema de coesão, não se pode afirmar que há um problema de atribuição de sentido a esse texto e que tão somente a retirada do pronome "eles" basta para evitar sua repetição no decorrer da narrativa.

A mesma consideração a respeito das anáforas indiretas ocorre em:

Exemplo 31. A dificuldade da aluna apresentada pelo texto é, entre outras, a inserção de elementos que não foram apresentados anteriormente. Nesse sentido, os bezerros "surgem" na história sem nenhum vínculo com o primeiro parágrafo e a referência a Débora se faz no mesmo momento que o marido, que até então fora sequer mencionado. Além disso, a eliminação das constantes repetições “quando eles (foram)" tornaria o texto mais limpo e claro. Por fim, sugere-se a inclusão de uma vírgula após a locução adverbial de modo.* Com as alterações propostas o segundo parágrafo ficaria assim:

"Quando foram dormir, perceberam a correria dos bezerros e foram ver o que estava assustando (os animais). De repente, um caranguejo gigante os atacou com uma patada só. A esposa, chamada Debora, começou a chorar, dizendo que queria ir embora."

* ou colocar a frase na ordem direta, como está na alteração. (resposta 104- grifo nosso)

Esse formando buscou várias justificativas normativas para garantir a limpeza e a clareza do texto. Essas justificativas seriam: a eliminação dos pronomes "eles", a inclusão de vírgula, o uso da ordem direta.

Exemplo 32. "Quando amanheceu, o barco não encontrava-se no lugar que a família o deixara. Foi encontrado um caranguejo em um penhasco e a família o empurrou ribanceira abaixo. O marido de Débora desmaiou e a família foi procurar ajuda na ilha".

A escritora deveria descrever as personagens ou ao menos os nomes dos componentes da família; a retirada dos pronomes pessoais (eles) contribuiria a um melhor entendimento da redação; a explicação da última frase poderia aumentar a capacidade de entendimento do leitor. (resposta 46grifo nosso)

Nessa resposta, o formando, além de considerar que a repetição do pronome "eles" prejudica o entendimento da redação, acredita que a mudança de "seu irmão" para "família" 
poderia contribuir para "aumentar a capacidade de entendimento do leitor", mesmo tendo havido alteração no que a menina estava pretendendo contar.

A repetição de palavras é também vista como um problema em:

Exemplo 33. No segundo parágrafo a primeira alteração seria o número excesivos de "eles" que são invãos, pois se colocar somente o primeiro "eles", no restante com a ajuda de elípses, você obtém com os verbos entendimento.

A segunda alteração seria retirar o que e o quando do texto após o "e" que liga uma coisa a outra e dá para se entender. Este "quando" que é um advérbio de tempo não teve necessidade junto com o "que ", era preciso neste caso somente o "e" para ter a função de uma continuação ou uma ligação de um termo ao outro.

Se você utiliza o de repente que é um tempo breve também, não precisa do quando também. (resposta 65- grifo nosso)

O uso da elipse proposta nessa resposta refere-se à consideração de que a repetição das palavras pode prejudicar o entendimento do texto. As demais alterações sugeridas referem-se à tentativa de buscar na gramática normativa uma maneira adequada de responder à questão. Ele buscou encontrar palavras que pudessem ser retiradas ou alteradas, relacionando texto coeso e compreensível com simples união de itens gramaticais.

Em outras respostas, além da retirada dos pronomes repetidos, há também a sugestão de recorrer a períodos curtos para tornar o texto mais claro ou, mais explicitamente, recorrer às regras gramaticais para aumentar a possibilidade de compreensão por parte do leitor.

Exemplo 34. Uma solução para a questão dos elos coesivos é a utilização de elipse para evitar a repetição do pronome "eles", também, podemos fazer uso de períodos curtos para melhor clareza do texto.

Outro ponto importante é pontuar o parágrafo adequadamente com a intenção de tornar clara a mensagem.(resposta 100- grifo nosso)

A idéia de texto como transmissor de uma mensagem que deve ser clara por causa da organização de elementos gramaticais também está presente nessa resposta. A ela está associada a noção de que os períodos curtos são mais fáceis de serem compreendidos, o que nem sempre é verdade. A resposta seguinte traz a indicação de que as regras gramaticais podem garantir uma maior clareza ao texto:

Exemplo 35. O segundo parágrafo do texto contém repetições e mal uso de coesões. Sugiro que seja menos repetitivo quanto aos pronomes, que seja mais sequencial para demonstrar o desenvolvimento dos fatos, que a pontuação esteja de acordo com as regras gramaticais, proporcionando melhor compreensão do conteúdo. Os sujeitos devem ser melhor definidos de acordo com suas ações para não causar confusão ou ambigüidade. 
"Quando foram dormir, perceberam que os bezerros começaram a correr. Foram ver o que estava assustando-os e, de repente, com uma só patada, um caranguejo gigante os atacou. Débora, que era esposa de..., começou a chorar dizendo que queria ir embora. (resposta 156- grifo nosso)

Nota-se, nesse exemplo, que as repetições são citadas como causadoras de problemas para a "compreensão" do texto produzido pela menina. As regras gramaticais deveriam ser respeitadas para que houvesse clareza no texto e ele fosse compreendido. Fica clara, portanto, a idéia de sentido único que orienta essa concepção de leitura.

O uso de períodos curtos facilitaria o entendimento da mensagem, como se pode verificar no exemplo [34]. Isso nos remete à visão de texto como soma de frases e de frase como soma de palavras. De acordo com essa perspectiva, se as frases fossem curtas, seria mais fácil reconhecer e entender as informações transmitidas. Esse é um índice da consideração da leitura como decodificação, característico da concepção tradicional, a qual também prevê, como nos exemplos apresentados nos quadros a seguir, que a pontuação seja condição indispensável para a atribuição de um único e determinado sentido a um texto.

Exemplo 36. “... Quando foram dormir, eles perceberam que os bezerros começaram a correr, então foram ver o que estava assustando os bezerros. De repente, eles foram atacados por um caranguejo gigante. Débora, a esposa começou a chorar dizendo que queria ir embora..."

O uso excessivo do pronome eles pode ser eliminado, pois o próprio verbo aponta a que pessoa ele se refere. A inserção de vírgulas, ajuda na interpretação da frase, pois sem o uso delas, a frase fica muito longa e confusa. $\mathrm{Na}$ frase: "Quando eles de repente com uma patada só um caranguejo gigante os atacou..." há uma incoerência, pois o autor começou dizendo "eles" que deveria haver um verbo posterior referente a ele, porém, ao invés disso, diz que o caranguejo gigante os atacou; para dar maior ênfase às personagens "eles", optei pelo uso do sujeito paciente: "eles foram atacados...”.(resposta 29- grifo nosso)

De uma maneira curiosa, ao considerar que os períodos longos são mais difíceis de serem interpretados, o formando sugere a inserção de vírgulas e não de ponto final.

Exemplo 37. Quando eles foram dormir, perceberam que os bezerros começaram a correr. Foram ver o que os assustava. Foram surpreendidos por um enorme carangueijo que os atacou com um só patada. Debora começou a chorar dizendo que queria ir embora.

Soluções: Redução de frases: Frases longas embaralham as idéias e prejudicam a coesão.

Pontuação: A pontuação adequada e usada convenientemente, auxilia na coesão textual.

Frases truncadas, deixam o texto sem sentido.

Colocação pronominal correta. (resposta 134- grifo nosso)

Esse formando também considera o uso de pontuação e de frases curtas e escritas em ordem direta como elementos facilitadores na compreensão de textos. 
Exemplo 38. Proponho que haja uma redução no uso dos pronomes pessoais de terceira pessoa (eles) fazendo o uso de recorrências anafórica e assim possibilitaria uma leitura mais solta e coesiva.

Um outro importante seria o de usar a pontuação correta. Para que as orações do texto sejam completas e com sentido possibilitando ao leitor uma compreensão melhor do conteúdo tratado, em especial destaco o uso correto da vírgula pois é a sua inadequação que compromete todo o sentido do texto.

Ao introduzir o segundo parágrafo há uma necessidade grande de se descrever o local da ação bem como a apresentação das personagens principais para que se entenda todo o enredo. (resposta 191- grifo nosso)

Já esse formando considera a vírgula com elemento capaz de garantir o sentido do texto. O mesmo pode ser observado em:

Exemplo 39. "Quando eles foram dormir, eles perceberam que os bezerros começarm a correr e então eles foram ver o que estava assustando os bezerros. Quando, de repente, com uma patada só, um caranguejo gigante os atacou..."

O problema da falta de vírgulas faz com que o texto fique desorganizado.

*O uso da conjunção "então", no lugar de "que quando" indica sequência de ações a qual acontece no texto.

*Se tirarmos o pronome "eles", que estava sem função no texto, podemos entender melhor oque a autora quer dizer. (resposta 241- grifo nosso)

A organização do texto - conseguida com a não repetição de palavras, com a troca de conjunções e com a inserção de vírgulas - poderia garantir a compreensão de seu sentido. No exemplo [40], a vírgula é garantia para "tomada" de fôlego na leitura. O formando considera que a menina, ao escrever "do mesmo modo que fala" está tornando a sua narrativa confusa:

Exemplo 40. "À noite, quando todos foram dormir, notaram o alvoroço dos bezerros, preocupados buscaram saber o motivo da agitação dos bichos. De repente, não se sabe de onde, surgiu um caranguejo gigante que os atacou com uma patada. Débora, que estava entre eles, chorando, disse que queria ir embora."

O texto da garotinha tem sério problema de usar conjunções subordinativas sem que haja uma oração principal em relação a ela. Ao ler, notamos que ela não toma fôlego, escreve do mesmo modo que fala, e como é uma histórinha de perigo e suspense, ela não pontua e atropela a narração. (resposta 243grifo nosso)

A pontuação seria, portanto, um modo de tornar os períodos mais curtos e, por isso, mais claros. Ela se faz necessária, segundo essa perspectiva, para que o texto seja compreendido pelo leitor, já que todo o sentido deve ser apreendido a partir da soma de elementos gramaticais.

Essa crença nos remete ao surgimento dos sinais de pontuação. Na Idade Média, com o surgimento da leitura silenciosa, os textos escritos precisaram de algumas características 
gráficas apropriadas à leitura visual. Surgiram, então, a separação de palavras, os sinais de pontuação e o contraste entre maiúsculas e minúsculas.

Ao comentar as práticas de leitura na Alta Idade Média, Parkes (In: CAVALLO e CHARTIER, 1998, p. 114) afirma que, “com o aumento do número de leitores, a preocupação com sentido ou significado de um texto, que está por trás da interpretação fornecida pelas estruturas sintáticas, levou a modificações no uso da pontuação”.

A partir dessa afirmação, podemos verificar que as respostas apresentadas trazem a combinação de pressupostos característicos das concepções tradicional - por considerarem que os períodos curtos são mais claros - e estruturalista (que será abordada a seguir) - por darem destaque à estrutura textual e indicarem que o sentido (único) do texto é planejado, de maneira consciente, pelo autor .

Segundo Gadet e Hak (2001:1997), "Pêcheux recusa completamente a concepção de linguagem que a reduz a um instrumento de comunicação de significações que existiriam e poderiam ser definidas independentemente da linguagem, isto é, "informações" (p.25). Essa concepção, ao considerar o leitor e o autor como meros receptores e transmissores de informações, apaga as dissimetrias características das condições de produção do discurso. Para esse autor, a linguagem não serve apenas para comunicar, mas também para negar informações. Para Pêcheux, a comunicação, na linguagem, é "somente a parte emersa do iceberg” (op. cit., p.26).

Na divisão proposta por Possenti (2001), em que a história da leitura teria passado por três estágios ${ }^{24}$, essa concepção corresponderia ao primeiro deles, chamado pelo autor de leitura filológica, na qual o autor desempenha papel central e a língua é vista como transparente.

Dando ao autor pleno poder de determinação de sentido para o texto, essa concepção pode, portanto, ser relacionada à visão de texto como soma do sentido de palavras e de frases para que as informações possam ser transmitidas por meio da leitura.

\footnotetext{
${ }^{24}$ Possenti (2001) propõe a divisão da história da leitura em três estágios: leitura filológica, leitura estrutural e leitura discursiva.
} 


\section{b. Concepção estruturalista}

A concepção tradicional apresentada neste trabalho corresponde ao que Pêcheux (AAD69) chama de ênfase à função da língua, sendo diferente do que foi proposto no estruturalismo, ou seja, a ênfase ao funcionamento da língua.

Pêcheux considera que

o deslocamento conceptual introduzido por Saussure consiste precisamente em separar essa homogeneidade cúmplice entre a prática e a teoria da linguagem: a partir do momento em que a língua deve ser pensada como um sistema, deixa de ser compreendida como tendo a função de exprimir sentido; ela torna-se um objeto do qual uma ciência pode descrever o funcionamento (retomando a metáfora do jogo de xadrez utilizada por Saussure para pensar o objeto da lingüística, diremos que não se deve procurar o que cada parte significa, mas quais são as regras que tornam possivel qualquer parte, quer se realize ou não).(op.cit. p.62)

$\mathrm{Na}$ concepção estruturalista, ler significa buscar a organização do texto, tendo em vista o que Pêcheux considerou como funcionamento da língua. Tendo recebido influência do estruturalismo, essa concepção centra a análise no texto, considerando-o fechado num sentido único, sem a exploração de suas funções sociais como compreensão da realidade. Assim, uma leitura seria mais correta quando depreendesse do texto seu sentido, sem se preocupar em fazer relação com qualquer elemento exterior.

Ao propor uma maior preocupação com o funcionamento da língua (em vez da função, como era previsto na concepção tradicional), o estruturalismo consolidou a consideração de língua enquanto sistema.

Para Coracini (2005), a concepção estruturalista de leitura acredita que o texto teria uma essência, ou seja, uma verdade absoluta, que deveria ser resgatada a partir da leitura.

"O estruturalismo, como sabemos, vê a língua e, como decorrência, o texto como uma estrutura, um todo passível de ser deslembrado em unidades menores, que, uma vez observadas e estudadas em seu funcionamento, podem ser recompostas de modo a reconstruir o objeto (texto, organismo animado ou inanimado)" (CORACINI,op.cit., p.20).

Maingueneau (2004: 2001) também critica essa visão estruturalista, comentando que $a$ "idéia de um enunciado que possua um sentido fixo fora de contexto torna-se insustentável" (p.20). Ao descartar do texto suas condições de produção, a compreensão do texto torna-se 
muito restrita, limitando-se apenas ao plano do enunciado, sem considerar as marcas que ele traz da enunciação.

Assim, segundo essa concepção, todo texto teria um funcionamento interno para a transmissão de um sentido previamente determinado e único. $\mathrm{O}$ ato interpretativo compreenderia a capacidade de o indivíduo perceber como o texto é organizado e, a partir disso, o que estaria pretendendo dizer. $\mathrm{Na}$ verdade, importaria mais saber como o texto articula internamente, estruturando o que diz. A noção de leitura aceitável não seria buscada na intenção do autor, uma vez que o leitor deve encontrar as respostas para suas indagações no próprio texto.

Apesar de toda crítica em torno do estruturalismo, não podemos nos esquecer de que ele nos trouxe um grande avanço nos estudos de texto. Para citar uma de suas contribuições com relação à interpretação, podemos nos lembrar do distanciamento da figura do autor da do narrador do texto. Foi importante perceber que aquele que diz "eu" no texto é um sujeito que se constrói ao longo de uma seqüência narrativa, a partir de toda uma organização interna do texto para que seja possível ao leitor diferenciar autor de narrador.

Outra mudança em relação à concepção tradicional foi que a soma linear de letras para a leitura de palavras só seria prevista para as que fossem desconhecidas, uma vez que já se imaginava que o leitor fosse capaz de identificar integralmente, "numa vista de olhos", as palavras conhecidas.

Segundo Bourdieu (apud Chartier, 2001, p. 233), verifica-se, no que o autor chama leitura estrutural,

\footnotetext{
"a leitura interna que considera um texto nele mesmo e por ele mesmo, que o constitui como auto-suficiente e procura nele mesmo sua verdade, fazendo abstração de tudo o que está ao redor".
}

Pode-se, pois, concluir que, ao lado de uma concepção de texto como um todo organizado e de língua como sistema, há uma concepção de sujeito como verificador dos elementos do texto para a busca do sentido depositado em seu interior, as quais, em conjunto, constituem uma concepção de sentido como único e depreensível exclusivamente do enunciado.

Nas respostas dos formandos, foi recorrente a afirmação de que o texto deveria ter somente uma possibilidade de interpretação, como uma alusão ao sentido único e préestabelecido, conforme podemos observar a seguir: 
Exemplo 41. Faria o uso de conjunções, pronomes relativos afim de retirar elementos repetidos e elementos que nos remetem a variadas interpretações.

Com isso, pode-se tornar o texto mais apto ao entendimento de todos, colocando-o corretamente às normas gramaticais. (resposta 98- grifo nosso)

Para o texto ser compreendido, segundo esse formando, ele não poderia dar margem a mais de uma interpretação. Assim, os "elementos que nos remetem a variadas interpretações" devem ser corrigidos, com a utilização dos conhecimentos da Gramática Normativa, o que demonstra que, nessa resposta, foram apresentadas as concepções estruturalista e tradicional de leitura.

Exemplo 42. Quando foram dormir, perceberam que os bezerros começaram a correr, foram ver o que estava assustando os bezerros. De repente, com uma só patada um caranguejo gigante os atacou.

Débora, sua esposa começou a chorar dizendo que queria ir embora.

Não colocar vírgulas em locais inadequados, pois dará outro sentido ou a falta de entendimentos da frase.

Se já foi citado uma vez que quem se fala, não há necessidade de repetir a palavra.

A inversão de palavras pode nos facilitar o entendimento da frase. (resposta 137- grifo nosso)

O mesmo pode ser verificado em [42], pois o texto, para esse formando, só pode ter um sentido (concepção mais próxima à visão estruturalista) e esse sentido se constrói pela soma dos significados das frases (concepção tradicional).

Mistura semelhante aparece em [42]:

Exemplo 43. Em relação ao segundo parágrafo, há um problema na maneira que as idéias, os fatos, são colocados; Não tem sentido lógico numa primeira leitura; É preciso usar pontuação adequada (vírgula, ponto e vírgula), para assim dividir os fatos, as ações e organizar as idéias no texto, para que ele venha a fazer sentido; além disso, há muita redundância neste parágrafo, o que torna a leitura além de difícil quanto ao entendimento, cansativa, por não ter objetividade em expôr os fatos. (resposta 254grifo nosso)

Os fatos devem ser expostos de maneira lógica para que a leitura seja facilitada. Ao possuir uma organização interna, o texto passa a ter sentido.

Exemplo 44. Essa família, com certeza, escolheu uma boa aventura, só que o texto que aduz essa aventura não apresenta-se de maneira adequada, já que recorre a muitas repetições com as palavras: "eles" e quando.

Observa-se que este fragmento produz ambigüidade o que não é recomendado em um texto para não provocar mais de uma significação, sendo um exemplo do que menciono, o parágrafo dois do texto, deixando-nos sem saber ao certo se foram os bezerros que deram patadas no caranguejo ou se ocorreu o contrário.

Observa-se também sérios problemas de pontuação e que, se fosse sanado, talvés amenizasse até os paralelismos e as ambigüidades.

A falta de coesão e de coerência em um texto geram problemas lingüísticos sérios que, só são sanados, quando o interessado em produzir qualquer tipo de texto, tenta seu aprendizado para que jamais sinta-se inferiorizado. (resposta 256- grifo nosso) 
Já no exemplo [44], a ambigüidade não pode ocorrer "em um texto para não provocar mais de uma significação", já que a organização é muito importante para a transmissão do sentido. No entanto, nenhum leitor imaginaria que os bezerros teriam atacado os caranguejos, uma vez que, na história, eram os primeiros que corriam assustados. Assim, essa ambigüidade encontra-se no plano lingüístico, mas não impede a compreensão dessa passagem do texto quando se pensa, por exemplo, no funcionamento pragmático da linguagem.

Observa-se que essas respostas, ao reconhecerem o fato semântico da ambigüidade, vêem-no como problemático, argumentando a favor do texto como um todo fechado, com sentido único, o qual poderia ser facilmente transmitido, segundo alguns formandos, se a menina seguisse a ordem cronológica dos fatos para narrar seu texto. Isso pode ser verificados nas respostas apresentadas a seguir.

Exemplo 45. No segundo parágrafo, a menina esteve confusa, talvez pela quantidade de idéias que ela queria passar em sua redação.Após alternado, o parágrafo ficaria da seguinte forma:

"Ao anoitecer, a ilha era tomada pela escuridão e a família por sua vez pelo cansaço da viagem, que pegaram no sono. Toda essa paz foi interrompida pelo barulho causado pelos bezerros. A família levantou e todos foram ver o que acontecia, notaram que havia o ataque de um caranguejo gigante. Esse horrível acontecimento assustou Débora, esposa que junto com o marido e seus filhos, resolveu passar as férias naquela ilha desconhecida.

As soluções para os elos coesivos são seguir a ordem dos fatos; primeiro anoiteceu, segundo a família adormeceu e terceiro acordaram com o ataque e ficaram assustados. Assim a pessoa que ler o texto, com certeza, não terá dúvidas quanto a informação transmitida pelo mesmo. Pode-se também fazer uso das metáforas. (resposta 28- grifo nosso)

Ao pensar na seqüência dos fatos como maneira de tornar o texto mais claro, o formando faz referência à organização interna do texto, vinculando sua resposta ao que pode ser considerado novamente como uma visão estruturalista, em [46],

Exemplo 46. A aluna da $4^{\text {a }}$ série (pela idade) poderá elaborar seu texto utilizando-se de outros elementos coesivos, pois está fazendo uso repetitivo da conjunção "Quando", em momento que poderia utilizar-se de outras conjunções, para enriquecimento e melhor clareza de seu texto.

Precisa também estabelecer uma seqüência para os acontecimentos dos fatos, uma cronologia. No $2^{\circ}$ parágrafo usa o termo "sua esposa" sem antes ter dito a quem se refere esse termo "sua esposa"(Não utilizou a coerência referencial). Seu texto tem sentido, porem a coerência está comprometida. (resposta 51- grifo nosso)

há a consideração de que a clareza do texto pode ser melhorada a partir de uma cronologia empregada às ações da narrativa da menina. Isso também ocorre nas respostas a seguir, que serão comentadas no final da série (após o exemplo 51). 
Exemplo 47. A coesão pode ser restabelecida no segundo parágrafo com a eliminação dos pontos finais, pois algumas orações mostram idéias incompletas, como, por exemplo, na primeira oração isso ocorre. É evidente que se os pontos finais forem retirados o texto deverá sofrer uma reestruturação com relação a seus elemento coesivos, as conjunções e pronomes relativos, afinal, da forma como o texto foi escrito é possível compreender o que a criança quer contar, porém, a falta de coesão gera falta de conexão entre as idéias.

Outra forma de resolver os problemas de coesão no parágrafo em questão seria um reordenação da idéias, de forma que uma seqüência fosse obedecida, pois o autor desse texto colocou os fatos de uma maneira que parece demonstrar ausência de uma seqüência lógica. $O$ autor, para escrever dessa forma, deveria utilizar os sinais de pontuação de maneira diferente a fim de evitar problemas de coesão textual. (resposta 66- grifo nosso)

Exemplo 48. Quando conseguiram chegar até a ilha, estavam tão cansados que resolveram dormir.

De repente, ouviram um barulho e foram ver o que havia acontecido.

Os bezerros que ali estavam, corriam sem parar, pois haviam sido atacados por um caranguejo gigante.

Débora. mãe das crianças, assustou-se começando a chorar e disse que queria ir embora.

A primeira sugestão foi primeiramente dizer que tinham conseguido chegar até a ilha para depois dizer o que havia acontecido, seguindo a ordem dos fatos. (resposta 72- grifo nosso)

Exemplo 49. Ao anoitecer, notaram que os bezerros corriam rapidamente. Assustaram-se - Foram atacados por um caranguejo gigante. Débora, chorando muito, pede para irem embora daquele lugar.

Justificativa $\rightarrow$ Segundo Saussure, o significado e o significante tem que haver um significado, uma representação. Neste, segundo parágrafo, não há clareza dos acontecimentos, não tendo nem sequência dos fatos.

Ocorrem problemas com os sintagmas, faltando objetividade. (resposta 132- grifo nosso)

Exemplo 50. A segunda frase "e quando eles foram" deveria ser substituida por: "e então foram" pois é impossível compreender se as pessoas estavam indo dormir ou estavam indo ver o que estava acontecendo. É preciso ter uma sequência de fatos.

A frase "Quando eles" iniciando a segunda parte do parágrafo deveria ser retirada pois não dá sentido, ou melhor, a frase não respeita a gramática normativa pois não pode estar ligada ao restante dela que é: "um caranguejo os atacou".

Além disso "com um patada só" deveria vir entre vírgulas pois é um adjunto adverbial de modo deslocado e todo termo deslocado deve vir entre vírgulas. (resposta 211- grifo nosso)

Exemplo 51. "Quando eles foram dormir, eles perceberam que os bezerros começarm a correr e então eles foram ver o que estava assustando os bezerros. Quando, de repente, com uma patada só, um caranguejo gigante os atacou..."

*O problema da falta de vírgulas faz com que o texto fique desorganizado.

* O uso da conjunção "então", no lugar de "que quando" indica sequência de ações a qual acontece no texto.

*Se tirarmos o pronome "eles", que estava sem função no texto, podemos entender melhor oque a autora quer dizer. (resposta 241- grifo nosso)

Essa cronologia indicada pelos formandos parte do pressuposto de que o texto deve ser claro, organizado internamente para que a mensagem seja perfeitamente compreendida. Prevê a narrativa apenas como seqüência de ações e fatos. Considerando, portanto, a ordem cronológica como essencial para a compreensão do texto. 
No entanto, ao observarmos o texto "O outro lado da ilha", verificamos que as ações nele apresentadas seguem uma ordem cronológica, tendo sido respeitado o ponto de vista da família, do que aconteceu a ela na ilha.

Conforme já vimos, Possenti (2001), ao dividir a história da leitura em três estágios, indicou que o segundo desses estágios consiste nas transposições de características da langue de Saussure para o texto, tendo ele passado a ocupar o lugar central no âmbito da leitura. Esse estágio se aproximaria ao que acabamos de expor como sendo a concepção estruturalista de leitura.

\section{c. Concepção cognitivista}

A concepção cognitivista reconhece que a leitura é um processo que começa no momento em que o cérebro recebe a informação visual e termina quando essa informação é associada aos conhecimentos prévios (experiências de mundo e de linguagem) que o leitor adquiriu.

Ganham relevância no leitor a memória, a percepção, o raciocínio e a linguagem. Assim, seria mais bem sucedido o leitor mais maduro, pois teria maiores condições de compreender textos que exigissem conhecimentos prévios e um maior conhecimento lingüístico.

Usando estratégias diferentes para apreender as informações contidas nos diferentes textos, são o interesse pelas informações e o objetivo da leitura que determinam as várias formas de ler disponíveis ao leitor.

Frank Smith, psicolingüista que estudou os processos interativos envolvidos na leitura, reconhecia a utilização de duas espécies de informação: a informação visual, recolhida através dos olhos, e a informação não-visual, que está disponível na memória do leitor, sendo que este recurso não-visual seria responsável pela economia da informação visual, uma vez que permitiria que o leitor antecipasse o que se encontraria logo adiante no texto. Assim, 'saber ler' não significaria utilizar toda a informação visual disponível, mas apenas a que fosse suficiente para a compreensão de um determinado texto, respeitando-se o que se pretendia com tal leitura (Martins, 1982).

Essa consideração está aliada ao que propôs Goodman, em 1967, a respeito dos dois modelos de processamento para a leitura: um que consistiria nas estratégias de busca das 
informações visuais do texto (chamado de bottow-up) e outro que se pautaria na consideração das informações não-visuais (chamado de top-down).

Esse modelo bottow-up, ou ascendente, seria correspondente ao que chamamos, neste trabalho, de concepção tradicional, pois consiste na decodificação do texto. Segundo o modelo top-down, ou descendente, a leitura de um texto não é linear, sendo que o leitor é a única fonte de sentido: faz uso intensivo de informações não-visuais e se apóia, principalmente, em seus conhecimentos prévios.

Por meio do input lingüístico, o leitor seleciona apenas algumas pistas que lhe permitirão reduzir incertezas ao testar as hipóteses que foram levantadas antes da decodificação do texto. Assim, conforme vimos, ler implica também a recolha de informação visual, porque a leitura não consiste numa atividade gratuita de adivinhações. Quando a informação visual é insuficiente, as previsões tornam-se aleatórias.

O modelo top-down baseia-se nas concepções chomskyanas, ao considerar que o leitor possui uma competência lingüística que o torna apto a compreender não só o que está escrito, mas também o que está implícito. Assim, o leitor é caracterizado como um processador ativo de informação. A leitura é um jogo de adivinhação, na qual o sujeito, em contato com a língua, testa hipóteses.

A concepção cognitivista preocupa-se também com a memória para a atribuição de sentidos ao texto. Tendo o cérebro identificado a informação visual, ela é encaminhada para a memória de curto prazo, que tem uma capacidade de cerca de cinco a nove itens. Depois de ser atribuído um significado a esses itens, eles são enviados para a memória de longo termo.

A memória de curto prazo ou memória imediata armazena as unidades que vão entrando e se caracteriza por ter uma capacidade limitada. Ela pode guardar entre 5 a 9 elementos e logo deve ser esvaziada para a entrada de outros elementos, caso contrário, ficará sobrecarregada. A memória imediata não faz nenhuma discriminação em relação ao tipo de unidade que é armazenada, contanto que sejam unidades significativas.

Uma vez que a memória é esvaziada e um dado material não pode ser reconhecido como unidade significativa, ele será imediatamente esquecido. Mas, se o material for significativo, ele passa a receber a ação de um outro tipo de memória, cuja capacidade não é limitada. Ela é chamada de memória profunda ou de longo prazo e organiza todo o conhecimento que envolve a língua, as experiências, as convicções, os hábitos.

Além desses tipos de memórias, uma estratégia importante para a leitura é a inferência, caracterizada por ser uma atividade necessária para a identificação e a organização dos elementos essenciais ou centrais do texto. Ela auxilia a codificação do texto na memória, 
facilitando, conseqüentemente, o processo de evocação do material gráfico. A inferência do conhecimento do vocabulário e do conhecimento prévio, na compreensão, atuam de forma mais evidente na evocação do conteúdo do texto.

De forma claramente distanciada da recepção passiva envolvida nas concepções tradicional e estruturalista, o leitor, na concepção cognitivista, utiliza conhecimentos muito variados para obter informação do escrito e reconstrói o significado do texto ao interpretá-lo de acordo com seus próprios esquemas conceituais e a partir de seu conhecimento do mundo.

Assim, este modelo permite realçar que o leitor não é uma espécie de "decodificador"” mecânico. A leitura é um ato de inteligência que implica o uso de estratégias diversificadas: previsão, confirmação e seleção.

Segundo Martins, o grande mérito da concepção cognitivista foi o de perceber que " $o$ leitor pré-existe à descoberta do significado das palavras escritas; foi-se configurando no decorrer das experiências de vida, desde as mais elementares e individuais às oriundas do intercâmbio de seu mundo pessoal e o universo social e cultural circundante” (p. 17).

Pode-se, pois, concluir que, ao lado de uma concepção de texto como produto do pensamento do autor e de língua(gem) como representação deste pensamento, há uma concepção de sujeito como um sujeito de "competências", aquele que pode captar o conteúdo do texto ao testar e confirmar hipóteses de leitura. Em conjunto, essas concepções constituem uma concepção de leitura diferente das perspectivas tradicional e estrutrualista, mencionadas anteriormente.

De fato, a possibilidade de encarar o leitor como um sujeito que testa hipóteses para buscar a comprovação do sentido imaginado previamente para um determinado texto constituiu um grande avanço nos estudos a respeito da leitura. Observe o exemplo abaixo:

Exemplo 52. Quando foram dormir, perceberam que os bezerros começaram a correr, e logo foram ver o que estava assustando os animais. De repente, com uma só patada, o carangueijo gigante os atacou. Débora, a mãe da família começou a chorar dizendo que queria ir embora.

A menina faz muito uso da palavra "eles", sabemos que eles são a família. (resposta 10grifo nosso)

Ao associar a palavra "eles" a "família", o formando mostra que compreende a anáfora indireta ${ }^{25}$ utilizada pela menina. Assim, faz referência a seu conhecimento de mundo,

\footnotetext{
${ }^{25}$ As anáforas indiretas não são associadas a elementos do cotexto. Elas estão ancoradas em condições cognitivas e/ou pragmáticas. Em outras palavras, o conhecimento de mundo do leitor possibilita a compreensão dessas anáforas, que não são consideradas como casos de falta de coerência no texto.
} 
o que mostra que "família" é sempre composta por mais de um elemento e, por isso, pode ser retomada no texto por um pronome que esteja no plural, sem causar qualquer prejuízo à compreensão do texto.

Em [53],

Exemplo 53. Um problema de coesão

Considerando-se o texto em questão, notamos que o segundo parágrafo deste apresenta informações novas que dão continuidade à narrativa. Porém, há um problema se observarmos como são feitas as ligações coesivas no texto, pois o leitor não dispõe de informações implícitas ou explícitas a tais informações que lhe permitam estabelecer uma relação coesa entre os fatos narrados nos outros parágrafos. Pode-se solucionar o problema das seguintes formas: algumas informações deveriam ser explicitadas formulando-se um parágrafo entre o primeiro e o segundo para que alguns fatos como o que havia do outro lado da ilha, por exemplo, fossem entendidos, selecionar as idéias que realmente são importantes para a narrativa e explicitá-las de modo que sejam coesas com o que está sendo narrado; acrescentar mais informações para que a narrativa seja entendida como um todo de sentido. (resposta 81 - grifo nosso)

o leitor é aquele que precisa associar as "informações implícitas ou explícitas" aos seus conhecimentos prévios para conseguir compreender o texto. As anáforas indiretas revelam a associação de uma determinada informação com o conhecimento que o sujeito tem, por exemplo, de "família", como um grupo ou instituição formada por mais de uma pessoa.

Muitos formandos referiram-se à idade da autora do texto, associando-a a fatores distintos, como podemos verificar nos exemplos a seguir, alegando:

- desconhecimento de normas gramaticais, necessárias ao entendimento do texto por parte do leitor -

Exemplo 54. Quando eles foram dormir, eles perceberam que os bezerros começaram a correr e quando foram ver o que estava assustando os bezerros. Quando, de repente, com uma patada, um caranguejo gigante os atacou. Débora, que era sua esposa, começou a chorar dizendo que queria ir embora.

Justificativa - Ela usa o termo excessivo da palavra quando e um parágrafo quase sem pontuação. Pela idade da menina, 10 anos, não conhece todas as regras gramaticais e a forma como escreve é de fato prematura deixando de dizer e fazendo conexões entre uma frase e outra, causando com isso, um texto não entendível. E também porque o seu pensamento está transportado para o texto, da forma que ela imagina. Apenas de que nessa idade é quase que comum as crianças fazerem isto. (resposta 226- grifo nosso)

- $\quad$ possível falta de conhecimento para produção de textos coesos e coerentes -

Exemplo 55. A primeira alteração eu faria (retirando a repetição do pronome "eles"), a seguir, acrescentaria palavras que dessem mais coerência ao explicar o ataque do caranguejo gigante. Depois, eu diria quem era o esposo da Débora, pois ficou implícito no texto.

Eu quero ressaltar que o texto foi escrito por uma criança de apenas dez anos, sendo assim, esta não possui conhecimento suficiente para elaborar um texto com coesão e coerência. Mesmo assim, a menina conseguiu produzir um texto que foi possível entender o seu significado. Sendo assim, 
fica claro que como a lingüística propõe, o importante não são as regras gramaticais, mas o significado da mensagem que nós passamos ao receptor. (resposta 273-grifo nosso)

A partir de tais exemplos, podemos notar que os formandos realmente consideram a idade como um fator importante para a produção de textos coerentes, aliando-a à escolaridade e, conseqüentemente, a letramento. É importante salientar que, ao considerarem o nível de escolaridade como diretamente relacionado a letramento, esses sujeitos optam pelo modelo autônomo como a opção teórica de alguns estudiosos, criticados por Street (1994: 1983), que consideram o letramento como uma tecnologia neutra, na qual se destaca a preocupação com o desenvolvimento da racionalidade (pensamento abstrato) e da lógica. Por muitas vezes, verifica-se a associação do letramento autônomo com o domínio do código escrito. Essa visão foi fortemente criticada pelo modelo ideológico de letramento, defendido por Street. Segundo essa visão, a menina de 10 anos deteria um certo grau de letramento não só por dominar o código escrito, mas também por associá-lo a práticas socioculturais (como a de contar história) com as quais tem ou teve contato.

Possenti (2001), em sua consideração a respeito da história da leitura, indica que, quando surge a consideração do leitor no momento da leitura, esta passa a ser vista de uma maneira diferente, menos unilateral. Acreditamos que a concepção de leitura aqui apresentada como cognitivista, embora ainda desconsidere o aspecto sócio-histórico dessa prática, poderia ser vista como um primeiro passo para o que o autor considera leitura discursiva.

\section{d. Concepção interacional}

Na concepção interacional, a leitura é um ato social entre dois sujeitos - leitor e autor que interagem através do texto.

Ainda que mobilize diversos níveis de conhecimento - lingüístico, textual e o conhecimento de mundo - para reconstruir o sentido do texto, formulando hipóteses antes de iniciar a leitura, o leitor tem objetivos bem claros ao fazê-lo e desenvolve essa atividade por meio do resgate de pistas disponíveis no texto, apontando para o que o autor objetiva comunicar. Em outras palavras, o autor tem intenções ao escrever de uma determinada maneira e o leitor deveria ser capaz de reconhecê-las para compreender não só o que está escrito no texto, mas também o que está subentendido. 
Para a concepção interacional, o autor é, em última instância, o responsável pelo sentido do texto. "É ele que, conscientemente, imprime marcas de suas intenções no texto" (CORACINI, 2005, p.21). O autor determina possibilidades de leitura, deixando pistas para que o leitor. É a interação entre dois sujeitos intencionais que caracteriza essa concepção. Surge, a partir de então, a consideração do aspecto social, de interação entre dois sujeitos mediante a leitura.

O sentido de um texto é, portanto, construído na interação texto-sujeitos. Aproxima-se, portanto, da atividade de leitura definida como "uma interação a distância entre leitor e autor via texto" (KLEIMAN, 2004b: 1989,p.65).

Entre essa concepção e as que se prendem ao texto como detentor do sentido (tradicional e estruturalista), há claras diferenças, dentre as quais destaca-se como a mais saliente a consideração do autor do texto como um interlocutor disposto a facilitar o trabalho do leitor, dando-lhe as pistas de que ele necessitaria para compreender o texto. Em relação à concepção cognitivista, pode-se dizer que a visão interacional da leitura pressupõe os procedimentos definidos por aquela concepção, mas não se identifica com ela. Para a concepção cognitivista, a compreensão do texto estaria centrada em competências lingüística, cultural, cognitiva - do leitor, enquanto que, para a concepção interacional, é reservado um papel fundamental também ao autor, bem como à relação que ambos estabelecem no momento da leitura.

Pode-se, pois, concluir que, ao lado de uma concepção de texto como possibilidade de interação entre autor e leitor e de língua(gem), isto é, como lugar que permite tal interação, há uma concepção de sujeito como aquele que busca as pistas impressas no texto, por um outro, tomadas como garantia de sua compreensão. Essas concepções, em conjunto, constituem uma concepção de leitura distinta da perspectiva cognitivista.

Em [56], pode-se observar a referência à interação autor/leitor:

Exemplo 56. Diante do conceito da menina em explorar as ligações coesivas, suas idéias estavam centralizadas em intimidar o leitor ou seja assustá-lo, pois a garota estava passando a maneira com que ela se sente diante de tantas coisas desconhecidas, entre elas, a linguagem. Para mudar esse problema dos elos coesivos: observamos que, podemos mudar o paragrafo mostrando uma saída para seus medos.

Quando eles foram dormir, sua mãe contava-lhes histórias, ensinava-lhes a conhecer opedaços por pedaços da ilha. Dona Débora morou em uma ilha e não havia mais barreras que o amedrontava, pois experiências e renovação leva a um conhecimento, os filhos entenderam e ao amanhecer foram embora. (resposta 17- grifo nosso) 
A menina, segundo esse formando, teria a intenção de assustar o leitor e teria realizado as escolhas lexicais e sintáticas em seu texto priorizando esse aspecto, deixando claras ao leitor essas pistas com o intuito de facilitar a leitura.

Em [57],

\section{Exemplo 57. A menina descreveu os fatos como se o leitor já tivesse um saber prévio dos mesmos. \\ Uma solução para esse problema seria uma apresentação mais abragente de local e personagens. \\ A segunda solução seria apresenta mais informações ao leitor sobre a decorrência os fatos, ela foi muito objetiva e esqueceu de detalhes importantes. \\ "...Quando eles de repente, com uma patada só um caranguejo gigante os atacou". Esta frase apresenta um forte traço de ambiguidade, o uso do pronome, mas este é um problema de português, o correto seria ler o que foi escrito. (resposta 270- grifo nosso)}

a menina é vista como uma autora que faz uma consideração a respeito do futuro leitor de seu texto. Ao ter em mente que conhecimentos ele teria, cria seu texto com as pistas de leitura necessárias para que a compreensão se concretize.

Em [58],

Exemplo 58. Através desta construção de texto a aluna não conseguiu alcançar um dos objetivos da língua escrita que é a troca de informações coerentes, havendo de se manter um elo de ligação entre o escritor e o leitor.

Faltaram maiores informações para que o texto fosse coerente e coeso. No entanto, a aluna demonstra criatividade, o que faltou foram maiores informações que terminassem por comprometer a coerência das informações fornecidas pelo texto. Mas, podem ser corrigidos através de leituras e incentivo a continuar produzindo textos, que a levarão ao melhoramento do raciocínio lógico e abstrato, sendo também aprimorados com o amadurecimento. Afinal de contas, se aprende a fazer, fazendo. (resposta 288- grifo nosso)

aparece, uma vez mais, a referência à troca de informações, inclusive transpondo a noção de "elos coesivos" para "elos de ligação entre o escritor e o leitor".

Todas essas respostas referem-se, portanto, à interação entre leitor e autor e às pistas que este último deveria fornecer para que o texto fosse compreendido.

Verifica-se que, apesar de pressupor uma interação entre autor e leitor, o autor é considerado, a exemplo da concepção estruturalista, como quem determina o sentido do texto. Sendo assim, a interação entre ambos decorre das marcas e pistas que são deixadas no texto para que seja possível a apreensão do sentido imaginado pelo autor. Essa seria a principal diferença entre essa concepção e a que apresentaremos a seguir: a discursiva. 
Possenti (2001), em sua consideração a respeito da história da leitura, indica que, quando surge a preocupação com o leitor como ser social - caso da concepção interacionista , a leitura passa a ser vista de uma maneira diferente de como era vista antes. Esse intercâmbio de caráter social, embora ainda desconsidere o fator "historicidade dos sujeitos", poderia ser visto, portanto, como correspondente a um segundo passo em direção ao que Possenti denomina leitura discursiva.

\section{e. Concepção discursiva}

Entendendo a leitura como uma atividade social, em que está presente o processo discursivo (ao mesmo tempo social e histórico), a concepção discursiva inclui o trabalho dos sujeitos envolvidos na atribuição de sentido ao texto.

No entanto, estando o autor, o leitor e o próprio texto imersos no processo discursivo, os sentidos não pertencem nem ao leitor nem ao autor, nem tampouco, estão, de modo exaustivo, registrados no texto. Existem também como partes de um processo: têm um passado e se projetam para um futuro, ou seja, têm historicidade. A língua, antes enfocada apenas como instrumento de informação, é considerada em sua opacidade e o texto como um emaranhado de sentidos possíveis. Quanto ao sentido, está e não está no texto. Deste modo, quando se lê, deve-se considerar o que está dito e o que não está, mas que também significa, ou seja, é preciso considerar os implícitos, outro modo de dizer que é preciso recuperar o discurso nas relações interdiscursivas em que se define.

A concepção discursiva, como a estamos entendendo aqui, está vinculada à Análise do Discurso francesa. Por sua vez, muitos dos postulados da AD a respeito de leitura podem ser verificados nos estudos bakhtinianos, caso da releitura feita pelos teóricos da enunciação como Authier-Rezuz e analistas do discurso como Maingueneau. Por essa razão, reuniremos, nesta exposição, esses dois tipos de abordagem.

O sujeito-leitor está inserido no processo histórico de construção de sentidos, interpretando as suas relações com o mundo e, por vezes, recriando-o. Nessa perspectiva, a interpretação seria a construção de domínios possíveis. Dessa forma, interpretar como os discursos produzem algum sentido implica que os sentidos são constituídos ideologicamente, e, portanto, não são únicos. 
"Em uma instituição escolar, por exemplo, qualquer enunciação produzida por um professor é colocada em um contrato que lhe credita o lugar de detentor do saber"(MAINGUENEAU, 1997:1987, p.30). Qualquer enunciado que venha desse lugar recebe uma leitura diferente daquela que um enunciado que parte, por exemplo, de um aluno.

Bakhtin (2003:1979) reconhece que o leitor não apenas constrói os sentidos da leitura, mas é construído por esses sentidos. O leitor, ao percorrer um texto, aciona inúmeros outros textos que compõem o seu acervo e promove uma inter-relação entre eles. Os sentidos construídos podem variar de leitor para leitor porque cada um possui um repertório distinto ou, em termos da $\mathrm{AD}$, porque cada um recorre a sua memória discursiva.

Sabemos que a diversidade das produções de linguagem é infinita, mas nada caótica. Para Bakhtin (op.cit.), estende-se na direção do que ele chama "tipos relativamente estáveis de enunciados", característicos dos gêneros do discurso, para os quais os falantes são sensibilizados desde o início de suas atividades de linguagem. Assim, os gêneros do discurso são diferentes formas de uso da linguagem que variam de acordo com as diferentes esferas de atividade humana e representam uma economia cognitiva e comunicativa nos processos de troca verbal. Caracterizados por um conteúdo temático, uma estrutura composicional e um estilo, os gêneros do discurso orientam os sujeitos no momento da produção e da leitura de textos. Sabendo a que gênero pertence determinado texto, o leitor já antecipa o que se pode verificar em sua prática leitora, recorrendo à sua memória discursiva para acionar as outras leituras que já realizou de exemplares do gênero em questão.

O texto precisa de legibilidade para que seja entendido, mas ela não é garantida apenas por seus aspectos lingüísticos ou textuais, nem somente pelas habilidades cognitivas que possui o leitor. Contam, também, as condições de produção, os seus modos de relação, de produção de sentidos e a sua historicidade.

Para Bakhtin (2004: 1929, p. 132), para compreender a enunciação de outro sujeito, é necessário, para cada palavra, fazer corresponder

"uma série de palavras nossas, formando uma réplica. Quanto mais numerosas e substanciais forem, mais profunda e real é a nossa compreensão.

Assim, cada um dos elementos significativos isoláveis de uma enunciação e a enunciação toda são transferidos nas nossas mentes para um outro contexto, ativo e responsivo. A compreensão é uma forma de diálogo; ela está para a enunciação assim como uma réplica está para a outra no diálogo". 
Em virtude dessa atitude responsiva, o sujeito pode dialogar com o texto, confrontando sua historicidade com a materialidade nele expressa. Não existe, assim, uma única leitura possível para uma determinada obra. Chartier considera que "o leitor fica com a última palavra, que, contudo, não é a sua, e sim da sociedade que o faz falar" (apud ZILBERMAN, 2001, p. 86).

Desse modo, fica evidente que o sujeito é co-responsável pelo que lê, em virtude das diferentes condições de produção, dando lugar a que um mesmo texto possa ser lido de diferentes maneiras, pelo mesmo ou por diferentes leitores, em diferentes épocas. Se visto como sujeito de um discurso, pode ser pensado como "efeito de sentido entre locutores" (PÊCHEUX, apud GADET e HAK, 2001) e o texto como objeto lingüístico com começo, meio e fim, mas sempre incompleto, aberto a novas interpretações.

Para Maingueneau (2004: 2001), existem três competências essenciais para a prática da leitura: a competência enciclopédica, a competência lingüística e a competência genérica. A competência enciclopédica é aquela relacionada às experiências de vida da pessoa, ou seja, diz respeito a todo conhecimento construído por meio de sua interação com o mundo que a rodeia. A competência lingüística, da qual faz parte a capacidade de decodificação, consiste em conhecer o código e a estrutura da língua. E, por fim, a competência genérica, que seria a capacidade de identificar os gêneros discursivos e saber como se relacionar com eles.

Essas competências do leitor levam em consideração os aspectos sócio-históricos e lingüísticos. Daí depreende-se que a interpretação não poderia ser descartada de nenhuma das concepções citadas. No entanto, não se imagina, a não ser na concepção tradicional, que o simples reconhecimento de grafemas seria suficiente para que um texto fosse compreendido.

Dessa forma, a perspectiva discursiva opõe-se à idéia de leitura enquanto decodificação lingüística para apreensão de um sentido único atrelado à palavra, visto que, no ato da leitura, autor e leitor estarão produzindo sentidos. Opõe-se, também, à idéia de um autor onipotente, que deixa marcas no texto para facilitar o desvelamento do significado, porque a produção dos sentidos é realizada por sujeitos situados historicamente e que produzem sentidos a partir do lugar que ocupam.

Assim, "a incompletude e a heterogeneidade são constitutivas de todo e qualquer texto” (CORACINI: 2005, p. 36). Nessa relação intersubjetiva, a leitura pode ou não ser vista como produção ativa de sentidos. Se autor e leitor são vistos como simples reprodutores de sua memória discursiva, é ela que irão buscar na formulação e na leitura do texto. São, pois, inteiramente passivos de suas determinações histórico-ideológicas. No entanto, se nesses seus 
trabalhos, o observador pode ver expressividade e singularidade, tanto a produção como a leitura do texto dão margem a uma concepção de sujeito não inteiramente assujeitado.

Nesta última concepção de leitura, a compreensão é concebida não como uma recepção passiva, mas como um modo ativo, dialógico de resposta - interacional no sentido forte da palavra.

Pode-se, pois, concluir que, ao lado de uma concepção de texto como materialidade discursiva, há uma concepção de sujeito sócio-histórico que não lê apenas o que está presente no texto no plano do enunciado, mas também encontra neste um emaranhado de dizeres, de sentidos que ultrapassam sua ação intelectiva diante do objeto, trazendo à tona, de maneira inconsciente, a memória discursiva. Essas concepções de texto e de sujeito constituem, em conjunto, uma concepção de leitura distinta da perspectiva interacional e é chamada, neste trabalho, de concepção discursiva.

Em nosso corpus, não foram encontrados exemplos que fizessem referência a essa concepção de leitura.

Possenti (2001), em sua consideração a respeito da história da leitura, indica que, quando surge a vez do leitor, efeito da história, a leitura passa a ser vista como possibilidades de sentidos e não mais como depreensão de sentido único. Essa leitura é, portanto, a que, com o autor, chamamos de discursiva.

\section{f. Considerações acerca da referência das concepções de leitura nas respostas dos formandos}

As concepções e práticas de leitura orientam-se pelo modo como pensam a construção do sentido e estão vinculadas às concepções de sujeito, texto e língua(gem).

Partimos das considerações de Koch (2003) - a respeito de texto e leitura - para propor o quadro 1, de nossa autoria, que explicita as noções de língua, sujeito/leitor e texto, tomadas como modo de emergência de cada concepção de leitura apresentada neste trabalho: 
Quadro 1 - Diferentes noções de língua, sujeito e texto, compondo diferentes concepções de leitura.

\begin{tabular}{|c|c|c|c|}
\hline $\begin{array}{c}\text { CONCEPÇÕES } \\
\text { DE LEITURA }\end{array}$ & $\begin{array}{l}\text { NOÇÃO DE } \\
\text { LÍNGUA }\end{array}$ & $\begin{array}{c}\text { NOÇÃO DE } \\
\text { SUJEITO/ LEITOR }\end{array}$ & $\begin{array}{c}\text { NOÇÃO DE } \\
\text { TEXTO }\end{array}$ \\
\hline TRADICIONAL & $\begin{array}{l}\text { Código, instrumento de } \\
\text { comunicação. }\end{array}$ & $\begin{array}{c}\text { Passivo, decodificador } \\
\text { do texto. }\end{array}$ & $\begin{array}{l}\text { Produto da codificação } \\
\text { com conteúdo explícito. }\end{array}$ \\
\hline ESTRUTURALISTA & Estrutura, sistema. & $\begin{array}{c}\text { Dependente do } \\
\text { funcionamento } \\
\text { sistemático do texto, } \\
\text { busca o sentido contido } \\
\text { no limite deste. }\end{array}$ & $\begin{array}{l}\text { Todo organizado, com } \\
\text { sentido único, cujo } \\
\text { funcionamento interno } \\
\text { torna-se transparente } \\
\text { pela descrição, análise e } \\
\text { relação entre suas } \\
\text { partes. }\end{array}$ \\
\hline COGNITIVISTA & $\begin{array}{l}\text { Representação do } \\
\text { pensamento. }\end{array}$ & $\begin{array}{l}\text { Ser consciente que testa } \\
\text { suas hipóteses de } \\
\text { leitura. }\end{array}$ & $\begin{array}{c}\text { Produto lógico do } \\
\text { pensamento do autor. }\end{array}$ \\
\hline INTERACIONAL & $\begin{array}{c}\text { Representação do } \\
\text { pensamento, sendo o } \\
\text { lugar de interação entre } \\
\text { sujeitos. }\end{array}$ & $\begin{array}{l}\text { Ser consciente que } \\
\text { interage, por intermédio } \\
\text { do texto com o autor, } \\
\text { em busca de pistas para } \\
\text { compreender o texto. }\end{array}$ & $\begin{array}{c}\text { Produto lógico do } \\
\text { pensamento do autor, } \\
\text { dotado de pistas para } \\
\text { sua compreensão, } \\
\text { tendo, portanto, sentido } \\
\text { determinado por seu } \\
\text { produtor. }\end{array}$ \\
\hline DISCURSIVA & $\begin{array}{l}\text { Lugar material em que } \\
\text { se depositam os } \\
\text { sentidos cristalizados } \\
\text { pela história e se abrem } \\
\text { as possibilidades de } \\
\text { novos efeitos de } \\
\text { sentido. }\end{array}$ & $\begin{array}{l}\text { Posição permeada pela } \\
\text { ideologia e pelo } \\
\text { inconsciente, } \\
\text { constituído no processo } \\
\text { discursivo na relação } \\
\text { com o outro/Outro }\end{array}$ & $\begin{array}{l}\text { Tecido elaborado pelos } \\
\text { sujeitos envolvidos } \\
\text { consideradas as } \\
\text { condições de produção } \\
\text { e a memória discursiva. }\end{array}$ \\
\hline
\end{tabular}

Koch (op. cit.) afirma que, na concepção de língua como código (mero instrumento de comunicação) e de sujeito como decodificador de um texto, este é visto como simples produto da codificação de um emissor, bastando ao leitor o conhecimento do código, já que o texto,

\footnotetext{
${ }^{26}$ Para Pêcheux (AAD-69), o outro refere-se ao sujeito do inconsciente (como se fosse um outro eu), enquanto o Outro seria o social, as vozes do coletivo presentes na memória discursiva do sujeito (Gadet e Haks, p.177)
} 
uma vez codificado, torna-se totalmente explícito, ou seja, pode transmitir informações. Nessa concepção, o papel de decodificador/leitor é essencialmente passivo.

Ainda para a autora, no que se refere à concepção de sujeito, as várias correntes teóricas sobre leitura defenderiam diferentes papéis para o sujeito. Vejamos cada uma delas.

$\mathrm{Na}$ concepção tradicional, o sujeito, na posição de leitor, não passa de um decodificador do texto, na medida em que não busca senão os meios pelos quais se pode chegar ao sentido.

À concepção de língua como estrutura, corresponde, segundo essa autora, à de sujeito assujeitado, já que a idéia de sistema lingüístico não prevê nada que the seja exterior (a não ser em seu funcionamento na enunciação). O texto é o responsável pelo sentido e o papel do leitor é o de descobrir, em sua organização, o que o texto, por meio de suas relações internas, transmite.

$\mathrm{Na}$ concepção de língua como representação do pensamento e de sujeito como senhor absoluto de suas ações e de seu dizer, o texto é visto como um produto - lógico - do pensamento do autor. Ao leitor cabe captar, por meio de sua cognição, essa representação mental e as intenções do produtor, não lhe restando, portanto, senão um papel essencialmente passivo.

À concepção de língua como lugar de interação, corresponde a noção de sujeito como entidade psicossocial, sublinhando-se o caráter ativo dos sujeitos, sendo estes imaginados como conscientes, capazes de percorrer ou deixar pistas para a compreensão da mensagem do texto.

À concepção de língua como lugar material onde se realizam os efeitos de sentido, interagem sujeitos sócio-históricos que se constituem no processo discursivo, tendo a possibilidade para, muitas vezes, inconscientemente, ver surgir sua memória discursiva, com todo o conhecimento considerado adequado para a atribuição de sentidos a um texto.

Essas concepções, no entanto, normalmente, não aparecem de modo tão linear nas práticas de leitura. Quando se imagina, por exemplo, um leitor como meramente decifrador de sinais gráficos, tem-se uma visão passiva de sujeito que considera o texto e a linguagem como objetos fechados em si mesmos, tendo o leitor, nesse caso, como o único papel o de apreender o sentido - tomado como único - transmitido por meio de uma linguagem transparente. No entanto, não se pode considerar que haja uma associação direta, ou seja, não podemos imaginar que uma concepção de leitura " $x$ " determinaria uma prática de leitura também " $x$ ". Os sujeitos, ao se envolverem em práticas de leitura e de escrita, acionam suas memórias discursivas e estas não são compartimentadas nem se encontram somente no nível da 
consciência. Ao longo da vida, os sujeitos tomam contato com diversas concepções de leitura e, por isso, podemos afirmar que essa pluralidade constitui os discursos e os próprios sujeitos.

Segundo Grossmann (1996), no momento da leitura, outras vozes, por vezes distantes no lugar e no tempo, surgem. Essas vozes surgem da apropriação que o sujeito faz das formas discursivas elaboradas ao longo de sua vida, nas interações humanas. Assim, os formandos avaliados assumem um papel que julgam ser esperado para eles tendo em vista não só as condições de produção do Provão, mas todas as situações de avaliação de conhecimentos a que já foram submetidos.

Das 290 respostas analisadas, 161 (ou seja, 56\%) fazem alguma referência à maneira como os sentidos poderiam ser atribuídos ao texto da menina. Já apresentamos alguns exemplos na primeira parte deste capítulo. Em todas essas respostas, encontram-se indícios das concepções de leitura apresentadas. Conforme já observamos, duas ou mais concepções podem aparecer na mesma resposta. Isso ocorre porque são ativadas de maneiras diferentes, conforme o que os formandos consideram mais apropriado para atender às expectativas dos examinadores.

Assim, foi bastante freqüente, nas respostas presentes no corpus, a consideração de que o texto "O outro lado da ilha" poderia ou não ser compreendido por seu leitor, a partir de comentários encontrados nas justificativas para as alterações propostas pelos formandos ao segundo parágrafo do texto que integrava a questão. Consideramos como comentários as referências feitas, explicitamente, ao leitor, à coerência, à ambigüidade, bem como aos sentidos atribuídos ao texto.

Nessas 161 respostas, os formandos, ao se defrontarem com o texto nas condições de produção já descritas, expõem-se ao interdiscurso ${ }^{27}$ revelam suas noções acerca da leitura. Tornam-se, então, visíveis, em determinados momentos de suas respostas, repetições do jádito, que carregam consigo sua historicidade, seus diversos usos sociais.

Consideramos que todas as concepções de leitura verificadas nas respostas analisadas consistem em retomadas do já-dito, muitas vezes, aparecendo juntas umas das outras. Não há, portanto, um caráter de exclusão entre elas, uma vez que são construções discursivas a respeito de um mesmo objeto. Partimos da idéia de que as noções de língua, sujeito/leitor e texto orientam a formulação de cada uma das concepções, uma vez que, juntas, permitem o

\footnotetext{
${ }^{27}$ O interdiscurso, segundo Authier-Revuz (2004), se inscreve no nível da constituição do discurso, na medida em que trabalha com a re-significação do sujeito sobre o que já foi dito.
} 
estabelecimento de uma concepção de sentido. Sendo assim, tomando por base essas noções, pode-se detectar nos textos a quais concepções de leitura a que o formando se filia.

No material analisado, as concepções mais recorrentes foram a tradicional e a estruturalista. Elas apareceram isoladamente (38 respostas apresentam referência indireta à concepção tradicional e 36, à estruturalista, representando $46 \%$ das respostas analisadas) ou em combinação entre si (aparecem combinadas entre si - em $34 \%$ das respostas - e também com as concepções cognitivista e interacional, embora com estas só se combinem em 22 respostas, representando 13\%). Assim, as duas concepções mais freqüentes (tradicional e estruturalista) estão presentes em 93\% das referências realizadas nas 161 respostas em que se comentava a respeito dos efeitos de sentido produzidos pelo texto "O outro lado da ilha".

As concepções cognitivista e interacional estão apresentadas separadamente em apenas $7 \%$ das referências feitas pelos sujeitos. Conforme já comentamos, não houve nenhuma ocorrência da concepção discursiva.

A predominância das concepções estruturalista e tradicional parece ocorrer em virtude da proximidade que elas têm em relação à imagem de leitor como ser passivo diante do texto, sendo este último o depósito de informações preestabelecidas e transparentes e que só podem ser interpretadas de uma única maneira. Essa consideração a respeito do leitor é comumente observada nas escolas, onde o professor busca, no texto, a leitura institucionalmente prevista e considera erro qualquer outra possibilidade. É dessa forma que muitos leitores se constituem, a começar pelos próprios professores que, freqüentemente, inseguros em relação à sua leitura, ao utilizarem o livro didático, recorrem ao Livro do Professor para chegar à resposta prevista. Com relação aos alunos, acreditam não serem capazes de ler por não fazerem a mesma leitura de seus professores, mesmo que haja coerência entre os sentidos atribuídos por eles e o texto lido.

No caso do Provão, a situação torna-se preocupante, pois, muitos desses formandos podem ter-se tornado professores de língua materna. Se isso de fato ocorreu, podemos afirmar que a imposição do sentido único para o texto pode continuar a ser mantida inalterada no ensino.

Outro dado a ser considerado é a identificação, por parte da maioria dos formandos, do que faltava para que o texto da menina fosse compreendido. Em suas respostas, indicavam, baseados nas concepções de leitura a que recorreram, falhas no texto "O outro lado da ilha". Entretanto, podemos afirmar que, qualquer que seja a diretriz dada por uma das concepções de leitura, o texto permanece compreensível. 
Apresentaremos, no quadro 2, o que cada concepção indicaria como acerto da menina, ou seja, como o que existe no texto produzido por ela e que possibilita a compreensão do que ela produziu.

Quadro 2 - Possibilidades de compreensão do texto da menina a partir das concepções indicadas pelos formandos.

\begin{tabular}{|l|l|}
\hline CONCEPÇÕES & $\begin{array}{l}\text { O QUE PODE SER VERIFICADO EM “O OUTRO LADO DA ILHA" } \\
\text { PARA POSSIBILITAR SUA LEITURA. }\end{array}$ \\
\hline Tradicional & $\begin{array}{r}\text { Há o emprego correto de estruturas sintáticas, como por exemplo em: } \\
\text { "Essa história começa com uma família que vai a uma ilha passar suas férias". } \\
\text { É possível unir as frases que compõem os parágrafos e compreendê-las, } \\
\text { pois a ordem cronológica seguida no texto parte da observação dos personagens } \\
\text { que compõem a família que estava na ilha. }\end{array}$ \\
\hline Estruturalista & $\begin{array}{r}\text { O texto está organizado em parágrafos que procuram narrar as férias de } \\
\text { uma família. } \\
\text { Existe uma organização interna nesse texto, uma seqüência de ações, } \\
\text { apesar da ambigüidade existente nele. }\end{array}$ \\
\hline Cognitivista & $\begin{array}{r}\text { O leitor pode acionar seu conhecimento de mundo para testar suas } \\
\text { hipóteses de leitura e compreender perfeitamente o sentido do texto }\end{array}$ \\
\hline Interacional & $\begin{array}{r}\text { A autora do texto deixa as pistas necessárias para o leitor compreender } \\
\text { a narrativa que produziu. }\end{array}$ \\
\hline
\end{tabular}

É compreensível que os formandos, em situação de avaliação e em função do enunciado da questão, tenham sentido necessidade de observar falhas no texto-base. Pode-se dizer que essa atitude foi, até mesmo, incentivada pela própria questão. No entanto, mais do que a situação da prova e o comando de uma questão, podemos dizer que essa procura pela falta no texto-base é uma construção sócio-histórica institucionalmente marcada pela escola, já que esta, muitas vezes, associa o papel do professor ao de identificador de falhas nas produções de seus alunos. Com relação aos acertos, estes raramente são buscados, sequer como contraponto às falhas apontadas.

O encaminhamento da questão, a partir da consideração de problemas na organização textual, fez com que os formandos se distanciassem da concepção discursiva de leitura. Ao sentirem a necessidade de comentarem problemas no texto de uma criança, recorreram à 
prática bastante comum na instituição e partiram em busca de falhas na estrutura do texto, desconsiderando a constituição da menina enquanto sujeito sócio-histórico.

No entanto, apesar de não terem se referido diretamente a essa concepção, todo tipo de produção de linguagem está ligado à memória discursiva, pois, conforme já foi mencionado, tudo o que eles já haviam ouvido/lido a respeito de texto e de leitura pôde ser observado em suas produções. Esse já-dito, submerso na memória discursiva desses formandos, possibilitou inclusive a aliança entre as concepções de leitura mencionadas.

\section{Procedimentos de análise}

Conforme já dissemos, não pretendemos nos ater a como deveria ter sido o ensino desenvolvido com os sujeitos analisados. Procuramos apenas apresentar nossas observações a respeito de como os leitores se constituem em suas práticas leitoras a partir de dados produzidos por sujeitos que se encontram no final do processo de educação formal, prestes a entrar para o mercado de trabalho, provavelmente para atuação na formação de novos leitores.

A análise da prática de leitura desses formandos partirá da consideração de que as concepções de leitura não se encontram compartimentadas na memória discursiva dos sujeitos. Elas se entrelaçam, fazendo-nos considerar que a leitura

\footnotetext{
"sempre carrega consigo uma postura teórica, ainda que não explicitada, já que partimos dos pressupostos de que teoria e prática se entrelaçam e se interpenetram - uma constitui a outra sem que se tornem um todo homogêneo - e de que é no espaço de tensão, que ocorre o processo de leitura" (CORACINI, 2005, p.15)
}

Todas as concepções de leitura apresentadas são construções sócio-históricas e, no sujeito, são construídas ao longo de suas diversas práticas de leitura. Elas decorrem das concepções de sentido que registramos em nossa memória discursiva e, por essa razão, estão presentes, direta ou indiretamente, nos textos dos formandos.

Uma outra maneira de apresentar as concepções de leitura é pensá-las como vozes presentes nos discursos. Como tais, entrelaçam-se, gerando o que chamaremos de "fios do tecido textual". Consideramos que toda leitura consiste em "desfiar" um tecido, a imensa 
gama de fios entrelaçados que compõem o texto. Por isso, a leitura não pode pertencer integralmente a uma ou outra concepção porque é constituída, assim como todo discurso, de maneira heterogênea. Como nos afirma Coracini (2005),

“(...) a incompletude e a heterogeneidade são constitutivas de todo e qualquer texto, o que equivale a dizer que nenhum texto é uno: assim como qualquer tecido (da pele ou do pano) esconde sua constituição heterogênea (células que se regeneram, fios que se cruzam e se entrelaçam), o texto escrito esconde, sob a superfície homogênea e una, o interdiscurso, rastros de outros dizeres, que se cruzam (o já dito, a memória discursiva) e que, vez por outra, emergem aqui e acolá, no fio do dizer, no intradiscurso" (p. 36).

Essa constituição heterogênea nos faz pensar na imagem de um tecido entrelaçado e desfiado inúmeras vezes pelos sujeitos (sejam eles produtores do texto e/ou leitores). Durante a produção e/ou leitura, a memória discursiva do sujeito emerge, e este procura agrupá-la de acordo com as escolhas temáticas e composicionais presentes no texto. Essas escolhas conferem ao sujeito as ilusões de unidade e originalidade. No entanto, sabe-se que todo texto é composto por diversas vozes, que representam o já-dito, como se fosse um emaranhado de fios que, ao se unirem e formarem o tecido, não são mais perceptíveis e conferem a ilusão de que sempre estiveram unidos, entrelaçados.

Essa imagem da leitura como tecido é bastante antiga e comentada por alguns autores, como por exemplo, Lajolo, para quem “a tecelagem, prática ancestral de fiar, de tingir e de urdir os fios, de entrelaçá-los em tecidos(,)[pode ser considerada a] matriz metafórica da leitura” (LAJOLO, 2004: 1994, p. 104). É essa maneira de entrelaçar fios sem se dar conta da multiplicidade de fatores que compõem o todo (tecido, o texto) que confere à leitura, conforme já afirmamos, a idéia de unidade, de busca de sentidos estáveis, únicos, que por tanto tempo foi a única maneira de se pensar nessa questão.

Por mais que se queira fugir dessa consideração, acreditamos que os sujeitos, a partir dos dois esquecimentos (Pêcheux \& Fuchs, apud GADET e HAK, 2001) teriam, no esquecimento número 2, a ilusão de busca de sentido único para uma dada formulação. Também ao ler um texto, o sujeito precisa da ilusão de ter encontrado exatamente o que o autor quis dizer, correspondentemente à necessidade do autor da ilusão de ter escrito exatamente o que imaginou para a constituição de seu texto. A esse esquecimento, alia-se o de número 1, a partir do qual o sujeito acredita ser a origem de seu discurso, o que faz com que se imagine fonte de sempre novos dizeres. 
É a partir também desses dois esquecimentos, principalmente do de número 2, que propomos a união de fatores comuns a essas concepções de leitura para que seja possível verificar como os formandos submetidos ao Provão 2001 referem-se a questões importantes no plano da leitura. É no sentido das formulações produzidas pelo esquecimento $\mathrm{n}^{\mathrm{o}} 2$ que se explica a partilha, entre diferentes concepções, de noções muito próximas, por exemplo, de sujeito e de sentido. Nas concepções tradicional e estruturalista, o sujeito é visto como passivo, uma vez que ele não passa de verificador do sentido do texto. Nas concepções estruturalista e interacional, o sentido é totalmente indicado no texto, a partir de sua organização (concepção estruturalista) ou das pistas deixadas pelo autor (concepção interacional).

Para conseguirmos entrelaçar os dados que compõem nosso corpus, recorreremos a um método interpretativo centrado nos dados disponíveis. Assim, não tentaremos impor categorias, mas analisar as pistas que se apresentam nas respostas dos formandos, vistos como sujeitos reais, singulares, à maneira do que propõe Ginzburg (1989) ao tratar do paradigma indiciário. Esse autor compara as variáveis que compõem uma pesquisa desenvolvida nesse paradigma aos fios de um tapete, à maneira do que descrevemos essa relação à elaboração do texto. Partindo desse pressuposto, buscaremos indícios para nossa interpretação com a intenção de associá-los às noções de sujeito, texto, língua e relação autor/leitor que serão expostas logo a seguir. Isso será feito para que possamos unificar as informações em uma interpretação que encontra seu significado nas concepções de leitura já apresentadas neste trabalho. Procurando seguir o que propõe Ginzburg (op.cit.), tentaremos percorrer "o tapete com os olhos em várias direções” (p. 170).

Neste momento de nossa análise, considerando o paradigma indiciário, eminentemente qualitativo, não mais nos interessaremos por levantamentos estatísticos ou quantitativos, mas pela relevância das pistas analisadas. Assim, importar-nos-emos com a singularidade dos dados e não com sua quantificação.

Tomando a leitura como intimamente ligada à questão do sentido e buscando uma integração dos pontos importantes e comuns às concepções analisadas nesse trabalho, sugerimos algumas concepções mais gerais de sujeito, texto, língua e relação autor/leitor, as quais podem ser verificadas nas diversas maneiras de se considerar e realizar a atividade leitora. A estas daremos o nome de parâmetros teóricos. Esses parâmetros traduzem o que os formandos imaginam por leitura e como eles a realizam no Provão. No próximo capítulo, associaremos esses parâmetros aos indícios encontrados nas respostas, tomadas como práticas de leitura dos formandos, já que estão intimamente ligados à atribuição de sentido ao texto. 
Consideradas as concepções apresentadas, temos os seguintes parâmetros, apresentados no quadro 3:

Quadro 3 - Parâmetros teóricos das concepções de sujeito, texto, língua e relação autor/leitor.

\begin{tabular}{|c|c|c|c|}
\hline SUJ & TEXTO & UA & $\begin{array}{c}\text { RELAÇÃO } \\
\text { AUTOR/LEITOR }\end{array}$ \\
\hline $\begin{array}{l}\text { S1. Ser intencional, } \\
\text { plenamente } \\
\text { consciente, capaz de } \\
\text { deixar ou percorrer } \\
\text { pistas para } \\
\text { compreensão do texto. }\end{array}$ & $\begin{array}{l}\text { T1. Meio para se chegar } \\
\text { a um sentido (texto visto } \\
\text { em sua função e não em } \\
\text { seu funcionamento). } \\
\text { T2. Organização } \\
\text { sistemática, fechada e } \\
\text { previamente planejada } \\
\text { para a transmissão de um } \\
\text { sentido (texto visto em } \\
\text { seu funcionamento). }\end{array}$ & $\begin{array}{c}\text { L3. Materialidade } \\
\text { lingüística, histórica e } \\
\text { social, reconhecida por } \\
\text { sua opacidade e por } \\
\text { permitir produção de } \\
\text { sentidos na linguagem } \\
\text { verbal. }\end{array}$ & $\begin{array}{l}\text { R1. O autor é visto } \\
\text { como o transmissor de } \\
\text { mensagens e o leitor é } \\
\text { um receptor passivo. } \\
\text { R2. Tanto o autor } \\
\text { quanto o leitor } \\
\text { procuram negociar } \\
\text { sentidos para o texto, } \\
\text { baseando-se nas pistas } \\
\text { presentes no texto. } \\
\text { R3. Autor e leitor são } \\
\text { papéis sócio- } \\
\text { históricos e, por isso, } \\
\text { são afetados por } \\
\text { diferentes vozes tanto } \\
\text { na leitura como na } \\
\text { produção de textos. }\end{array}$ \\
\hline
\end{tabular}

Essas concepções procuram reunir as principais considerações a respeito da leitura. Quanto às concepções de texto, temos em T1 um todo único pensado por seu autor e formado apenas pela soma linear de palavras, sendo visto tão-somente como meio de transmissão de mensagens, o que, em T2, só seria possível a partir da apreensão de sua organização interna. Diferentemente do que ocorre em T1 e T2, em T3, o texto não é um objeto transparente de veiculação de informações, mas um tecido permeado de vozes e, portanto, passível de múltiplos efeitos de sentido.

28 Foram propostas apenas duas noções de sujeito baseadas na consideração da presença ou ausência de atribuições de uma consciência plena no momento da leitura ou da produção de textos. 
Com relação à possibilidade de mais de uma atribuição de sentido para o texto, vale lembrar a consideração de Maingueneau, exposta por Brandão (1997), de que, no texto, há:

1) um movimento de expansão - por ser lacunar, o texto permite a proliferação de sentidos;

2) um movimento de filtragem - o locutor, através de determinadas estratégias, restringe essa proliferação levando o leitor a selecionar a interpretação pertinente. O leitor situa-se, portanto, num espaço ambíguo entre a disseminação de sentidos possíveis - a polissemia - e as coerções, as restrições inscritas na organização do texto.

Sendo assim, nem toda interpretação é possível para um texto. Existem restrições indicadas pelo próprio texto. Assim, a concepção T3 não desconsidera a organização do texto, mas também funciona para restringir a proliferação ilimitada de sentidos.

A concepção L1 indica apenas a função da língua e desconsidera seu funcionamento. É interessante verificar também que a concepção de língua L3 redimensiona L2, levando o caráter social da língua para a noção de sistema. Já as concepções de sujeito S1 e S2 mostram posições diferentes do sujeito. Em S1, temos sujeitos que procuram conscientemente compreender os textos ou produzi-los acreditando que o sucesso dessas atividades lingüísticas deva-se apenas e tão-somente aos conhecimentos acumulados e ativados conscientemente durante a leitura ou a escrita. Já em S2, temos um sujeito que não tem total consciência da origem de seus conhecimentos e produz um discurso entremeado de já-ditos.

Quanto à relação autor/leitor, temos, em R1, uma relação inexistente, que não é prevista na produção do texto, o que não ocorre em R2, já que o autor indica, durante a produção do texto, os passos que o leitor deve seguir para encontrar o sentido (único) que o texto apresenta. Em R3, essa tentativa de encontrar um modo de organização do texto para que o leitor chegue ao sentido imaginado por ele não passa de uma ilusão do sujeito e da falta de consciência de que autor e leitor são papéis sócio-históricos afetados pelas diferentes vozes que permeiam o discurso e sua materialização (o texto).

Notamos que, em todas as respostas, houve a consideração do sujeito como ser consciente, capaz de deixar em seu texto as marcas para sua compreensão ou , inversamente, capaz de percorrer o caminho deixado pelo autor, identificando essas pistas para depreender o sentido (único) que o texto traria.

São exemplos de respostas com manifestação do S1:

Exemplo 59. (...) A menina escreveu como estivesse contando (oral), desse modo, para o leitor, a leitura se torna pouco esclarecedora. Ela deveria ter eliminado o excesso de pronome (eles), adjunto adverbial(quando) e substantivo (bezerro) além de procurar esclarecer as duas últimas 
frases do segundo parágrafo, pois o uso do "de- repente" ficou mal empregado. Seria bem vinda o esclarecimento de que os bezerros foram atacados por um caranguejo gigante, no qual reagiram com uma patada que a esposa - Débora - faz parte da família citada acima. (resposta 88- grifo nosso)

Exemplo 60. Para solucionar este problema sem que se altere o parágrafo inteiro pode-se ou tirar algumas palavras, conjunções ou acrescentá-las. Isto dara maior coesão ao texto e até o colocaria mais dentro das normas da escrita por exemplo, o trecho; “....a correr e que quando eles foram..."poderia ser escrito de duas maneiras: “...a correr e eles foram... ou .... correr foi quando eles foram..."e desta forma corrige-se o emprego errado da conjunção que. (...) (resposta 118- grifo nosso)

Exemplo 61. Diante do conceito da menina em explorar as ligações coesivas, suas idéias estavam centralizadas em intimidar o leitor ou seja assustá-lo, pois a garota estava passando a maneira com que ela se sente diante de tantas coisas desconhecidas, entre elas, a linguagem. Para mudar esse problema dos elos coesivos: observamos que, podemos mudar o paragrafo mostrando uma saída para seus medos. (...) (resposta 17- grifo nosso)

O sujeito é visto como um ser intencional, que controla a atenção para verificação do que está presente num texto. Em todos esses exemplos, o leitor e o autor são vistos como seres plenamente conscientes que deixam ou encontram pontos facilitadores para a compreensão do texto, quer eles se apresentem na forma de itens gramaticais ou de sugestões para que a mensagem seja transmitida de maneira satisfatória.

Quanto às concepções de texto, temos apenas manifestações do que estabelecemos para T2: organismo fechado e previamente planejado para a transmissão de um sentido. A atribuição de mais de um sentido, historicamente constituído, para um texto não foi mencionada nem verificada no interior das respostas analisadas.

Como exemplos, temos:

Exemplo 62. O fato de se ter escrito "uma família" e, depois, só se referir a ela pelo pronome "eles"ocasiona uma falta de coesão, pois não dá para se saber, ao certo a quem se refere "eles". Outro ponto em que ocorre falta de coesão é no trecho "...os bezerros começam a correr e que quando eles foram ver o que estava assustando os bezerros.". A menina não completou a idéia e, em seguida, mencionou "caranguejo gigante", "elemento" que não havia aparecido e que não apresenta relação alguma com o texto. A menina deixou de pensar na coesão do texto, o que poderia ser corrigido, primeiramente, pela inserção de nomes próprios (os nomes das pessoas da família) para que, em um outro momento, seja possível se ter uma idéia mais clara da mensagem que pretende ser passada. (resposta 110- grifo nosso)

Exemplo 63. Uma solução para a questão dos elos coesivos é a utilização de elipse para evitar a repetição do pronome "eles", também, podemos fazer uso de períodos curtos para melhor clareza do texto.

Outro ponto importante é pontuar o parágrafo adequadamente com a intenção de tornar clara a mensagem. (resposta 100 - grifo nosso)

Exemplo 64. Os elementos de ligação interna do texto estão mal posicionados como por exemplo, o uso das vírgulas, das conjunções, o pleonasmo e outras traços próprios da linguagem oral de crianças nesta fase. Este conjunto, além da falta de coesão, causa também como conseqüência a incoerência, pois tais construções interferem diretamente uma sobre a outra, digo, interferem diretamente na inteligibilidade do texto, seria mais proveitoso que o professor como mediador, 
fosse lentamente, porém gradativamente adaptando o aluno ( no caso a menina) ao uso correto das formas por meio da língua oral (a padrão) inicialmente fazendo-o perceber como fazemos tais ligações de modo natural e espontâneo, como por exemplo a tomada de termo, quando fazemos isso não repetimos pleonasticamente; ou invocamos sistematicamente a pessoa do discurso. Após perceberem estas funções que fazemos naturalmente e usamos, seria aconselhavel aplicar o pronome de reescrita de seu próprio texto corrigindo as possíveis inadequações e escolhendo dentro de um campo semântico as palavras a serem utilizadas. (resposta 172- grifo nosso)

Exemplo 65. No segundo parágrafo dispensa-se o elemento coesivo referencial "eles" no início do período. Ainda que o sujeito torne-se elíptico é possível na leitura perceber seu referente, a família. Em seguida, retira-se um ponto e vírgula, continuando com o sujeito elíptico. Finalmente, após a palavras Débora, sujeito determinada desta oração, coloca o sintagma nominal "a esposa", entre vírgula para que seu esposo seja o chefe do referente família, e não o caranguejo. (resposta 74- grifo nosso)

Essas respostas referem-se a um modo bem comum de se imaginar o texto como detentor de uma verdade, de um sentido único, determinado pelo autor. O texto serviria então para apresentação da mensagem que o autor quis transmitir, indicando-lhe um domínio consciente e racional da língua para a exposição de seus pensamentos.

Ao verificarmos as concepções de língua nas respostas dos formandos, observamos que os formandos, no plano do enunciado, expuseram uma visão de língua como todo organizado, com sentido único, sem a consideração, na maior parte das respostas, de seu caráter social, interacional.

Algumas respostas consideram a língua como um código (L1):

Exemplo 66. (...) Por ser um texto produzido por uma menina de 10 anos devemos considerar que ela ainda não tem acesso a todos os tipos de normas e regras gramaticais e está num processo de aquisição das mesmas. As soluções seriam: retirar os pronomes "eles"pois não são necessários, substituir o artigo definido "os" por "uns" já que anteriormente não foi apresentado, no texto, nenhum bezerro, então são indefinidos, retirar "que quando eles" pois prejudica a coerência do texto e acrescentar vírgulas no termo "que era sua esposa" pois trata-se de um aposto explicativo e deve conter a vírgula. (resposta 112- grifo nosso)

Exemplo 67. O texto "O outro lado da ilha" traz referências para o problema da repetição na linguagem textual. Um texto para ser coerente deve ser elaborado de forma clara e precisa, sem repetições de palavras, pronomes, adjetivos etc.

No texto, a autora faz uso do pronome "ele" sucessivamente. Esse pronome poderia ser omitido em determinados períodos para que a informação fosse transmitida adequadamente e sem desvios. Assim, não só a linguagem ficaria apropriada, mas também o conteúdo ficaria mais significativo. (resposta 216- grifo nosso)

Vista como conjunto de sinais para transmissão de uma mensagem, a língua é tida nesses exemplos como uma união de elementos gramaticais capazes de tornar a mensagem clara. São as categorias gramaticais que fazem os formandos voltarem o olhar ao código, à língua vista unicamente como conjunto de elementos lingüísticos. 
Outras consideram a língua como um sistema organizado para estruturação de mensagens, indicando o que chamamos neste trabalho de L2.

Isso pode ser demonstrado a partir dos exemplos a seguir:

Exemplo 68. A menina repetiu várias vezes o pronome pessoal "Eles"na $1^{\mathrm{a}}$ oração. Neste caso ela poderia omitir os 2 seguintes que não iriam prejudicar sua estrutura. A segunda oração deste parágrafo não possuí sentido pois, a mesma não concluiu o pensamento, não havendo assim transmissão da mensagem. (resposta 136- grifo nosso)

Exemplo 69. (...) A terceira solução visa combinar as duas anteriores, adequando a introdução de elementos lingüísticos à presença de um antecedente lógico, ou tornando-os indefinidos ( uns bezerros, por exemplo) ou eliminando-os completamente (que era sua esposa), além de reordenar as frases evitando começá-las sempre pela mesma conjunção adverbial temporal ("quando") num jogo indefinido e recorrente de anáforas típicas de um discurso verbal ainda não pautado inteiramente pelo controle racional do texto escrito. (resposta 8- grifo nosso)

Exemplo 70. (...) Ao escrever um texto, o autor deve levar em conta os elementos de coordenação e subordinação, além de períodos curtos, evitando assim que o texto seja cansativo para o receptor da mensagem. (resposta 216- grifo nosso)

Exemplo 71. Quando eles foram dormir, perceberam que os bezerros corriam assustados. Foram ver o que acontecia e levaram uma patada de um caraguejo gigante. Débora começou a chorar querendo ir embora.

Os elos coesivos tem que aparecer seguindo a estrutura da gramática, aparecer dando sentido ao texto e como uma ligação de um periodo para outro. (resposta 59- grifo nosso)

A língua, nas respostas analisadas, é tratada como um conjunto de regras capaz de facilitar a transmissão e a organização de uma informação. Não importa somente os itens gramaticais utilizados, mas também a organização interna do texto, sendo percebida a língua enquanto sistema. Isso pode ser observado em todos os exemplos.

No exemplo [66], há, também, além da idéia de código, a consideração de que, quanto maior tempo de contato com a língua, mais seu domínio pode se aprimorar, garantindo uma maior sistematização de sua forma e, com isso, um sucesso maior na transmissão de mensagens. No exemplo [69], a partir de um controle consciente da estrutura da língua, o sujeito pode garantir uma transmissão mais agradável de sua mensagem. Apesar de considerar o efeito que uma mensagem pode causar no leitor, essa resposta ainda não indica a pressuposição de efeitos de sentidos possíveis para o texto, uma vez que a língua deveria estar organizada conscientemente para apenas tornar a apreensão do sentido único menos cansativa.

Quanto à relação autor/leitor, notamos que os formandos consideram que o autor deve indicar, a partir da estruturação de seu texto, o sentido que ele lhe havia determinado. Com isso, encontramos apenas referências a R2, como as que veremos a seguir: 
Exemplo 72. "Quando eles foram dormir, perceberam que os bezerros começaram a correr, e ao ouvirem o barulho, foram ver o que estava assustando os bezerros. De repente apareceu um caranguejo gigante, que com uma só patada, os atacou. Débora, a esposa, começou a chorar dizendo que queria ir embora". A menina, autora do texto original, ao passar para a linguagem escrita o que havia escutado da estória, escreveu um texto não muito objetivo para quem não a conhece. Ela não especificou as personagens e a situação por completo, deixando o leitor tentar advinhar o parentesco das personagens e a situação em geral. (resposta 164- grifo nosso)

Exemplo 73. Quando eles foram dormir, perceberam que os bezerros começaram a correr e ao irem ver o que estava assustando os bezerros pôdem observar que um caranguejo gigante os tinha atacado. Então, Débora que era sua esposa começou a chorar dizendo que queria ir embora.

Pode-se observar que no segundo parágrafo havia a falta de recursos linguísticos de ligação, ou melhor, a falta de coerência da idéia exposta pela autora do texto.

Para que um texto seja compreendido pelo leitor é extremamente relevante e importante coesão e coerência andarem juntas.

Portanto, se os conectores ou frases apresentarem uma clareza e uma boa articulação, dificulta a compreensão desejada e pretendida. (resposta 194- grifo nosso)

Exemplo 74. O texto "O outro lado da ilha" traz referências para o problema da repetição na linguagem textual. Um texto para ser coerente deve ser elaborado de forma clara e precisa, sem repetições de palavras, pronomes, adjetivos etc.

No texto, a autora faz uso do pronome "ele" sucessivamente. Esse pronome poderia ser omitido em determinados períodos para que a informação fosse transmitida adequadamente e sem desvios. Assim, não só a linguagem ficaria apropriada, mas também o conteúdo ficaria mais significativo.

Ao escrever um texto, o autor deve levar em conta os elementos de coordenação e subordinação, além de períodos curtos, evitando assim que o texto seja cansativo para o receptor da mensagem. (resposta 216- grifo nosso)

Exemplo 75. "Quando amanheceu, o barco não encontrava-se no lugar que a família o deixara. Foi encontrado um caranguejo em um penhasco e a família o empurrou ribanceira abaixo. O marido de Débora desmaiou e a família foi procurar ajuda na ilha".

A escritora deveria descrever as personagens ou ao menos os nomes dos componentes da família; a retirada dos pronomes pessoais (eles) contribuiria a um melhor entendimento da redação; a explicação da última frase poderia aumentar a capacidade de entendimento do leitor. (resposta 46- grifo nosso)

Exemplo 76. O segundo parágrafo poderia ser elaborado, alterando-se vírgulas, conjunções e a pontuação.

Os problemas de coesão levam a uma certa perda também da coerência nesse parágrafo, prejudicando e dificultando a compreensão do leitor.

As modificações nos elos de coesão (conjunções, vírgulas e pontuação) poderiam trazer maior clareza para o parágrafo, tanto do ponto de vista sintático como semântico e ainda melhorariam a compreensão do parágrafo por parte do leitor.

Alguns elementos do parágrafo ainda teriam que ser substituídos ou substraídos, como é o caso do pronome "sua", que aparece sem ter um referente nesse parágrafo. (resposta 83- grifo nosso)

A relação autor/leitor prevê toda a consciência do sujeito e associa-se ao que propusemos em S1. Por isso, acreditamos que há uma correlação entre esses dois parâmetros teóricos, uma vez que, nos dois, é desconsiderada a condição sócio-histórica dos sujeitos. 
Acreditamos que o fato de não termos encontrado, em nossa análise, respostas que indicassem as concepções de língua, texto, sujeito e relação autor/leitor integradas ao que é proposto na Análise do Discurso (S2, T3, L3 e R3) permite-nos duas considerações:

1. a própria questão do Provão não permitia uma visão da língua mais aberta à abordagem discursiva da língua, do texto e do sujeito, uma vez que se referia explicitamente a um problema de organização interna no texto "O outro lado da ilha", levando o formando a indicar falhas estruturais do texto;

2. em situação de avaliação, os sujeitos tendem a reproduzir o discurso que sentem ser mais valorizado, o que nos leva a crer que a formação desses formandos - não só na graduação, mas também ao longo de toda sua trajetória escolar - esteve marcada por pouca consideração dos aspectos sociais e históricos do discurso e restringiu-se mais a uma visão de uso da língua como aprendizagem consciente de aplicação de regras para transmissão de mensagens consideradas inequívocas.

Nosso próximo passo será apresentar os indícios reveladores das práticas de leitura anunciadas e realizadas nas/para as respostas dos formandos. Esses indícios serão associados, conforme já comentamos, aos parâmetros teóricos aqui expostos para que busquemos traçar como foi praticada a leitura no contexto enunciativo do Provão de Letras 2001. 


\section{Capítulo III}

\section{Indícios da prática de leitura dos formandos}

Partindo da constatação de que, na prática, as concepções de leitura estão entrelaçadas, neste ponto de nossa análise, observaremos as práticas de leitura dos formandos, dirigindo nosso olhar para alguns indícios observados em todas as respostas analisadas (as 290 que compõem nosso corpus), buscando verificar como foi realizada a leitura desses formandos no Provão. Do capítulo II, privilegiaremos a consideração dos parâmetros teóricos a fim de ver, de maneira integrada, as concepções de leitura apresentadas anteriormente.

Apropriando-nos do paradigma indiciário proposto por Ginzburg (1989), apresentaremos a seguir os indícios - encontrados nas respostas dos formandos.

Esses indícios encontram-se organizados de acordo com o que consideramos importante para revelar a leitura realizada pelos formandos. Em primeiro lugar, apresentou-se bastante curiosa a maneira como os formandos procuraram "corrigir" a ambigüidade presente no segundo parágrafo do texto da menina quando é narrado o seguinte: "Débora que era sua esposa começou a chorar dizendo que queria ir embora".

Ao se proporem melhorar esse trecho, houve várias sugestões, a saber:

\begin{tabular}{|l|l|}
\hline 1. Débora, sua esposa, & 15. Debora a esposa muito nervosa \\
\hline 2. Sua esposa Débora & 16. Débora a mulher, \\
\hline 3. Débora, uma da mulheres, chorosa & 17. Débora, a mãe, \\
\hline 4. Débora, a esposa, & 18. Assustada a mulher do casal \\
\hline 5. Débora, que era a mãe, & 19. Débora, que era a esposa do pai da família, \\
\hline 6. A mãe que se chama Débora, & 20. A esposa, chamada Debora, \\
\hline 7. Débora que era sua esposa & 21. Débora, esposa de Rogério \\
\hline 8. Débora, a mãe das crianças, & 22. Débora a esposa de um deles, \\
\hline 9. Débora & 23. Debora, que era a matrona da família \\
\hline 10. Débora, que era a mais medrosa, & 24. Débora, esposa de João, \\
\hline 11. Débora, que era esposa de João & 25. Débora que era um dos membros da família \\
\hline 12. Débora, que era esposa dum deles, & 26. Débora, a esposa de Douglas, \\
\hline 13. Débora a esposa assustada, & 27. Débora que fazia parte da família, \\
\hline 14. Uma das pessoas da família, Débora, & \multicolumn{2}{|l}{} \\
\cline { 2 - 2 } &
\end{tabular}

Todos os modos acima apresentados de alterar esse trecho do texto revelam a posição assumida pelo formando enquanto leitor do texto produzido pela menina. Alguns deles surgiram em mais de uma resposta, mas o que nos interessa, conforme já afirmamos, não é a quantificação desses indícios, mas o que acreditamos ser suas representações acerca de texto e de leitura. Verificamos que, para os formandos, a leitura deveria ter como objetivo procurar 
pontos em que o texto poderia ser melhorado (o que foi inclusive indicado na questão). A leitura seria vista, então, como a identificação de aspectos negativos num texto produzido por um a criança.

Mesmo havendo um grande número de formandos que fizeram referência à necessidade de pontuar corretamente o texto para que ele pudesse ser compreendido, não percebemos a recorrência dessa prática nas sugestões encontradas. Assim, eles pretendiam que a menina realizasse algo que não se demonstraram aptos a fazer na reescrita do texto. Essa inconsistência entre o que exigem e o que fazem exemplifica-se em:

\begin{tabular}{|l|l|}
\hline 3. Débora, uma da mulheres, chorosa & 18. Assustada a mulher do casal \\
\hline 6. A mãe que se chama Débora, & 21. Débora, esposa de Rogério \\
\hline 7. Débora que era sua esposa & 22. Débora a esposa de um deles, \\
\hline 11. Débora, que era esposa de João & 23. Debora, que era a matrona da família \\
\hline 13. Débora a esposa assustada, & 25. Débora que era um dos membros da família \\
\hline 15. Debora a esposa muito nervosa & 27. Débora que fazia parte da família, \\
\hline 16. Débora a mulher, & \multicolumn{2}{|l}{} \\
\cline { 2 - 2 } &
\end{tabular}

Outro ponto que nos interessa, talvez mais importante para nossa análise, é como esses formandos alteraram essa referência à personagem Débora, procurando melhorar a coesão textual. Essa alteração é reveladora da concepção de texto de que eles partem, pois indica como eles lidaram com a relação dessa personagem com a família apresentada na narrativa. Percebe-se, desse modo, que algumas sugestões buscaram "resolver o problema" de coesão textual utilizando informações já disponíveis no texto da menina, ou seja, apenas reorganizando a frase em que a referência a essa personagem é feita. Isso ocorre em:

\begin{tabular}{|l|l|}
\hline 1. Débora, sua esposa, & 7. Débora que era sua esposa \\
\hline 2. Sua esposa Débora & 20. A esposa, chamada Debora, \\
\hline 4. Débora, a esposa, & \multicolumn{2}{|l}{} \\
\cline { 1 - 2 } &
\end{tabular}

Nota-se que a solução para a ambigüidade apresentada no texto seria, segundo esses formandos, provocada pela simples reorganização desse trecho, revelando, dessa forma, respeito aos elementos já apresentados pela autora, ou seja, uma consideração de que o texto nos traz informações e que estas são definidas pelo autor, sendo que elas podem ser estruturadas de uma maneira mais adequada ao entendimento do leitor.

Outras sugestões que também partem dessa mesma consideração ora apenas apagaram a informação a respeito de Débora, mantendo somente o nome dessa personagem, ora incluíram alguma informação sobre ela encontrada no próprio texto (no cotexto). Isso ocorre em: 


\begin{tabular}{|l|l|}
\hline 9. Débora & 17. Débora, a mãe, \\
\hline 12. Débora, que era esposa dum deles, & 22. Débora a esposa de um deles, \\
\hline 14. Uma das pessoas da família, Débora, & 25. Débora que era um dos membros da família \\
\hline 16. Débora a mulher, & 27. Débora que fazia parte da família, \\
\hline
\end{tabular}

A concepção de texto vinculada a essa prática é similar à verificada anteriormente, nas outras sugestões já comentadas. Os formandos acreditam que o próprio texto fornece ao leitor todas as informações necessárias para seu entendimento.

Já nas demais sugestões, percebemos o acréscimo de informações para que a ambigüidade deixe de existir. É certo que algumas não são bem sucedidas, mas o que nos importa é verificar como eles se filiam a uma concepção de texto diferente da que aparece vinculada nas sugestões apresentadas anteriormente. Ao referir-se à Débora como "esposa de João" (11), “a esposa assustada" (13), “a esposa do pai da família” (19), “a matrona da família" (23) ou "a mais medrosa"(10), estavam surgindo para o enunciado elementos inferíveis do contexto e também do conhecimento de mundo do formando/leitor. O texto é visto, então, como portador de sentidos que nem sempre estão presentes, mas que também podem ser presumíveis, o que torna o leitor co-responsável pela atribuição de sentido, mesmo que este último seja visto como único e previamente estabelecido.

Esses indícios (surgidos nessas sugestões dadas pelos formandos) revelam, portanto, uma proximidade maior com alguns dos parâmetros teóricos já apresentados no capítulo anterior. Vejamos:

\begin{tabular}{|l|l|l|l|l|}
\hline \multicolumn{1}{|c|}{ Sugestões } & Sujeito & Texto & Língua & $\begin{array}{l}\text { Relação } \\
\text { autor/leitor }\end{array}$ \\
\hline 1. Débora, sua esposa, & $\mathrm{S} 1$ & $\mathrm{~T} 1 \rightarrow \mathrm{T} 2^{29}$ & $\mathrm{~L} 1 \rightarrow \mathrm{L} 2$ & $\mathrm{R} 1 \rightarrow \mathrm{R} 2$ \\
\hline 2. Sua esposa Débora & $\mathrm{S} 1$ & $\mathrm{~T} 1 \rightarrow \mathrm{T} 2$ & $\mathrm{~L} 1 \rightarrow \mathrm{L} 2$ & $\mathrm{R} 1 \rightarrow \mathrm{R} 2$ \\
\hline 3. Débora, uma da mulheres, chorosa & $\mathrm{S} 1$ & $\mathrm{~T} 2$ & $\mathrm{~L} 2$ & $\mathrm{R} 2$ \\
\hline 4. Débora, a esposa, & $\mathrm{S} 1$ & $\mathrm{~T} 1 \rightarrow \mathrm{T} 2$ & $\mathrm{~L} 1 \rightarrow \mathrm{L} 2$ & $\mathrm{R} 1 \rightarrow \mathrm{R} 2$ \\
\hline 5. Débora, que era a mãe, & $\mathrm{S} 1$ & $\mathrm{~T} 2$ & $\mathrm{~L} 2$ & $\mathrm{R} 2$ \\
\hline 6. A mãe que se chama Débora, & $\mathrm{S} 1$ & $\mathrm{~T} 2$ & $\mathrm{~L} 2$ & $\mathrm{R} 2$ \\
\hline 7. Débora que era sua esposa & $\mathrm{S} 1$ & $\mathrm{~T} 1 \rightarrow \mathrm{T} 2$ & $\mathrm{~L} 1 \rightarrow \mathrm{L} 2$ & $\mathrm{R} 1 \rightarrow \mathrm{R} 2$ \\
\hline 8. Débora, a mãe das crianças, & $\mathrm{S} 1$ & $\mathrm{~T} 2$ & $\mathrm{~L} 2$ & $\mathrm{R} 2$ \\
\hline 9. Débora & $\mathrm{S} 1$ & $\mathrm{~T} 1 \rightarrow \mathrm{T} 2$ & $\mathrm{~L} 1 \rightarrow \mathrm{L} 2$ & $\mathrm{R} 1 \rightarrow \mathrm{R} 2$ \\
\hline 10. Débora, que era a mais medrosa, & $\mathrm{S} 1$ & $\mathrm{~T} 2$ & $\mathrm{~L} 2$ & $\mathrm{R} 2$ \\
\hline 11. Débora, que era esposa de João & $\mathrm{S} 1$ & $\mathrm{~T} 2$ & $\mathrm{~L} 2$ & $\mathrm{R} 2$ \\
\hline 12. Débora, que era esposa dum deles, & $\mathrm{S} 1$ & $\mathrm{~T} 1 \rightarrow \mathrm{T} 2$ & $\mathrm{~L} 1 \rightarrow \mathrm{L} 2$ & $\mathrm{R} 1 \rightarrow \mathrm{R} 2$ \\
\hline 13. Débora a esposa assustada, & $\mathrm{S} 1$ & $\mathrm{~T} 2$ & $\mathrm{~L} 2$ & $\mathrm{R} 2$ \\
\hline 14. Uma das pessoas da família, Débora, & $\mathrm{S} 1$ & $\mathrm{~T} 1 \rightarrow \mathrm{T} 2$ & $\mathrm{~L} 1 \rightarrow \mathrm{L} 2$ & $\mathrm{R} 1 \rightarrow \mathrm{R} 2$ \\
\hline 15. Debora a esposa muito nervosa & $\mathrm{S} 1$ & $\mathrm{~T} 2$ & $\mathrm{~L} 2$ & $\mathrm{R} 2$ \\
\hline
\end{tabular}

\footnotetext{
${ }^{29}$ Ao colocarmos a seta $(\rightarrow)$, indicamos que o indício apresentado refere-se a uma concepção que se encontra entre o que propõe T1 e T2. O mesmo sinal será utilizado outras vezes com o mesmo sentido.
} 


\begin{tabular}{|l|l|l|l|l|}
\hline 16. Débora a mulher, & $\mathrm{S} 1$ & $\mathrm{~T} 1 \rightarrow \mathrm{T} 2$ & $\mathrm{~L} 1 \rightarrow \mathrm{L} 2$ & $\mathrm{R} 1 \rightarrow \mathrm{R} 2$ \\
\hline 17. Débora, a mãe, & $\mathrm{S} 1$ & $\mathrm{~T} 1 \rightarrow \mathrm{T} 2$ & $\mathrm{~L} 1 \rightarrow \mathrm{L} 2$ & $\mathrm{R} 1 \rightarrow \mathrm{R} 2$ \\
\hline 18. Assustada a mulher do casal & $\mathrm{S} 1$ & $\mathrm{~T} 2$ & $\mathrm{~L} 2$ & $\mathrm{R} 2$ \\
\hline 19. Débora, que era a esposa do pai da família, & $\mathrm{S} 1$ & $\mathrm{~T} 2$ & $\mathrm{~L} 2$ & $\mathrm{R} 2$ \\
\hline 20. A esposa, chamada Debora, & $\mathrm{S} 1$ & $\mathrm{~T} 1 \rightarrow \mathrm{T} 2$ & $\mathrm{~L} 1 \rightarrow \mathrm{L} 2$ & $\mathrm{R} 1 \rightarrow \mathrm{R} 2$ \\
\hline 21. Débora, esposa de Rogério & $\mathrm{S} 1$ & $\mathrm{~T} 2$ & $\mathrm{~L} 2$ & $\mathrm{R} 2$ \\
\hline 22. Débora a esposa de um deles, & $\mathrm{S} 1$ & $\mathrm{~T} 1 \rightarrow \mathrm{T} 2$ & $\mathrm{~L} 1 \rightarrow \mathrm{L} 2$ & $\mathrm{R} 1 \rightarrow \mathrm{R} 2$ \\
\hline 23. Debora, que era a matrona da família & $\mathrm{S} 1$ & $\mathrm{~T} 2$ & $\mathrm{~L} 2$ & $\mathrm{R} 2$ \\
\hline 24. Débora, esposa de João, & $\mathrm{S} 1$ & $\mathrm{~T} 2$ & $\mathrm{~L} 2$ & $\mathrm{R} 2$ \\
\hline 25. Débora que era um dos membros da família & $\mathrm{S} 1$ & $\mathrm{~T} 1 \rightarrow \mathrm{T} 2$ & $\mathrm{~L} 1 \rightarrow \mathrm{L} 2$ & $\mathrm{R} 1 \rightarrow \mathrm{R} 2$ \\
\hline 26. Débora, a esposa de Douglas, & $\mathrm{S} 1$ & $\mathrm{~T} 2$ & $\mathrm{~L} 2$ & $\mathrm{R} 2$ \\
\hline 27. Débora que fazia parte da família, & $\mathrm{S} 1$ & $\mathrm{~T} 1 \rightarrow \mathrm{T} 2$ & $\mathrm{~L} 1 \rightarrow \mathrm{L} 2$ & $\mathrm{R} 1 \rightarrow \mathrm{R} 2$ \\
\hline
\end{tabular}

Podemos afirmar que todas essas alterações partem do pressuposto de que o texto tem apenas um sentido, planejado pelo autor para ser identificado pelo leitor em virtude das informações presentes no texto ou das pistas deixadas pelo autor para que o leitor acione seu conhecimento de mundo. Todas essas atividades ocorrem, na visão dos formandos, de maneira consciente, ou seja, pela ativação consciente de esquemas de memória por parte do sujeito.

Acreditamos, portanto, que os formandos que conseguiram trazer para a alteração do texto seu conhecimento de mundo aderem a uma concepção de texto, de língua e de relação autor/leitor mais voltada para uma consideração da estrutura do texto e da consideração da língua enquanto sistema, estando mais preocupados com o funcionamento da língua do que com sua função (segundo proposição de Pêcheux, já exposta neste trabalho).

Percorrendo nosso material em busca de novos indícios, encontramos algumas afirmações referentes ao modo como esses formandos acreditam que se dê a coesão em textos. Para eles, faltavam ao texto alguns itens específicos que o deixavam sem coesão e, para alguns, também sem coerência. Algumas falhas apontadas em nosso corpus faziam referência a:

\begin{tabular}{|l|}
\hline - instrumentos anafóricos como a elipse, repetição desnecessária do pronome "eles" (resposta 3) \\
\hline - o emprego de anáforas no texto (resposta 3) \\
\hline - um antecedente lógico (resposta 8) \\
\hline - reordenar as frases evitando começá-las sempre pela mesma conjunção (resposta 8) \\
\hline - (evitar/retirar) reprise de palavras (resposta 22) \\
\hline - menção de algo que não havia sido dito antes (resposta 22) \\
\hline - seguir a ordem dos fatos (resposta 28) \\
\hline - a pontuação (deveria estar) de acordo com as regras gramaticais (resposta 156) \\
\hline - maiores informações para que o texto fosse coerente e coeso. (resposta 288) \\
\hline
\end{tabular}


A reprise de palavras, a falta de menção anterior de algo que surge no texto, a falta de respeito à cronologia dos fatos e a falta de conhecimentos gramática foram consideradas causadoras da falta de coesão no segundo parágrafo do texto da menina. Essa perspectiva tradicional de texto e de língua nos remete à consideração de que a leitura, para esses formandos, seria possível graças à soma de elementos gramaticais, os quais devem estar normativamente "corretos" para que a informação possa ser transmitida.

Ao apontarem essas falhas, os formandos revelaram a concepção de texto como um todo organizado pela soma de partes. Trata-se da visão de coesão apenas como ligação entre frases e parágrafos. Com isso, o texto é considerado uma estrutura organizada para que tenha o sentido apreendido pelo leitor.

Dois formandos referiram-se à coesão utilizando metáforas que indicam essa mesma concepção levantada nesses indícios. São elas: "formação de ganchos entre as orações" (resposta 18) e "canal para continuar a história" (resposta 236). Entender a coesão como gancho ou canal torna a crença a respeito de coesão bastante significativa para a concepção e a prática de leitura desses sujeitos. Ao utilizarem essas metáforas, eles revelam que, a exemplo da maioria dos formandos do município de São Paulo, percebem a leitura e a praticam como uma travessia por um texto que não pode ser prejudicada por nenhum obstáculo e, se, por acaso, surgirem lacunas ou pontos afastados entre as partes que o compõem, haveria a necessidade de ganchos que promovessem a união do que estava, a princípio, separado. Isso nos remete à freqüente alusão ao texto considerado incoeso como "colcha de retalhos". Para os formandos, não é, pois, considerado certo, num texto, a presença de lacunas, de tal modo que as vozes discursivas sejam submetidas a um mecanismo de padronização, de uniformização, para garantir a unidade e o sentido do texto.

Os indícios exemplificados partem dos seguintes parâmetros teóricos:

\begin{tabular}{|l|l|l|l|l|}
\hline & Sujeito & Texto & Língua & $\begin{array}{l}\text { Relação } \\
\text { Autor/ Leitor }\end{array}$ \\
\hline $\begin{array}{l}\text { - instrumentos anafóricos como a elipse, repetição } \\
\text { desnecessária do pronome "eles" (resposta 3) }\end{array}$ & $\mathrm{S} 1$ & $\mathrm{~T} 2$ & $\mathrm{~L} 2$ & $\mathrm{R} 2$ \\
\hline - o emprego de anáforas no texto (resposta 3) & $\mathrm{S} 1$ & $\mathrm{~T} 2$ & $\mathrm{~L} 2$ & $\mathrm{R} 2$ \\
\hline - um antecedente lógico (resposta 8) & $\mathrm{S} 1$ & $\mathrm{~T} 2$ & $\mathrm{~L} 2$ & $\mathrm{R} 2$ \\
\hline $\begin{array}{l}\text { - reordenar as frases evitando começá-las sempre pela } \\
\text { mesma conjunção (resposta 8) }\end{array}$ & $\mathrm{S} 1$ & $\mathrm{~T} 1$ & $\mathrm{~L} 1$ & $\mathrm{R} 1$ \\
\hline - (evitar/retirar) reprise de palavras (resposta 22) & $\mathrm{S} 1$ & $\mathrm{~T} 1$ & $\mathrm{~L} 1$ & $\mathrm{R} 1$ \\
\hline $\begin{array}{l}\text { - menção de algo que não havia sido dito antes } \\
\text { (resposta 22) }\end{array}$ & $\mathrm{S} 1$ & $\mathrm{~T} 1 \rightarrow \mathrm{T} 2$ & $\mathrm{~L} 1 \rightarrow \mathrm{L} 2$ & $\mathrm{R} 1 \rightarrow \mathrm{R} 2$ \\
\hline - seguir a ordem dos fatos (resposta 28) & $\mathrm{S} 1$ & $\mathrm{~T} 2$ & $\mathrm{~L} 2$ & $\mathrm{R} 2$ \\
\hline - a pontuação (deveria estar) de acordo com as regras & $\mathrm{S} 1$ & $\mathrm{~T} 1$ & $\mathrm{~L} 1$ & $\mathrm{R} 1$ \\
\hline
\end{tabular}




\begin{tabular}{|l|l|l|l|l|}
\hline gramaticais (resposta 156) & & & & \\
\hline $\begin{array}{l}\text { - maiores informações para que o texto fosse coerente } \\
\text { e coeso. (resposta 288) }\end{array}$ & $\mathrm{S} 1$ & $\mathrm{~T} 1 \rightarrow \mathrm{T} 2$ & $\mathrm{~L} 1 \rightarrow \mathrm{L} 2$ & $\mathrm{R} 1 \rightarrow \mathrm{R} 2$ \\
\hline
\end{tabular}

Diferentemente dessas indicações de falhas no texto da menina, alguns formandos centraram a atenção na autora dos textos para buscar a justificativa para os problemas dos elos coesivos. Isso foi encontrado em:

1. um texto produzido por uma criança de 10 anos, é escrito relatando o fato como realmente aconteceu no exato momento(...)Narra como se estivesse conversando com um amigo. (resposta 1)

2. a garota estava passando a maneira com que ela se sente diante de tantas coisas desconhecidas, entre elas, a linguagem. (resposta 17)

3. No segundo parágrafo, a menina esteve confusa, talvez pela quantidade de idéias que ela queria passar em sua redação (resposta 28)

4. Essa repetição é característica da oralidade, mas não cabe num texto escrito. (resposta 35)

5. o fluxo do pensamento da menina é inadequado para o texto escrito. (resposta 42)

6. A garota introduz outro elemento temporal e não completa o pensamento. (resposta 55)

7. a mesma escreve da forma que fala; sem convencionalismo. (resposta 90)

8. a maneira como a garota articula sua sintaxe dificulta a interpretação (resposta 92)

9. Por ser um texto produzido por uma menina de 10 anos devemos considerar que ela ainda não tem acesso a todos os tipos de normas e regras gramaticais e está num processo de aquisição das mesmas. (resposta 112)

10. a autora do texto escreve com vícios orais, ocorrendo um desvio da norma padrão. (resposta 120) 11. Em virtude da autora do texto ter apenas 10 anos, ela escreve como fala. Existe a presença marcante de traços da linguagem oral, como por exemplo a repetição excessiva de pronomes, palavras; a falta de coordenação entre as frases; a falta de coodenação verbal etc. (resposta 122)

12. ela não termina seus assuntos. (resposta 161)

13. Ela não especificou as personagens e a situação por completo (resposta 164)

14. Ao ler, notamos que ela não toma fôlego, escreve do mesmo modo que fala, e como é uma histórinha de perigo e suspense, ela não pontua e atropela a narração. (resposta 243)

Esses formandos, ao referirem-se ao problema de coesão, atribuíram-no à pouca idade da menina e a seu conhecimento limitado da norma padrão. Outro fator considerado foi a presença de traços da oralidade no texto escrito, o que, para eles, não poderia ter ocorrido. Todas essas justificativas partem de uma visão de língua escrita como mais complexa do que a língua falada. Esses formandos, portanto, acreditam que a menina seja capaz de se comunicar bem oralmente, mas não consegue produzir textos escritos adequadamente em virtude de considerarem a escrita mais complexa, recorrendo à visão da "grande divisa", já apresentada neste trabalho.

Ao procurarem maneiras de "resolverem" o problema" colocando-se na posição de professores da menina, alguns formandos propuseram algumas estratégias que levariam a menina a melhorar a produção de seus textos.

A menina, assim, estaria mais próxima das sociedades consideradas iletradas por não dominar, segundo os formandos, perfeitamente a língua escrita. Essa visão é muito 
questionável, já que vimos, no capítulo I, que essa criança já domina muitos aspectos da língua escrita e do gênero com que trabalhou na produção de seu texto.

As estratégias propostas para a "resolução" de problemas existentes no texto da menina são:

1. sugerindo a releitura do texto, criando condições que o aluno perceba a quantidade de (palavras) termos repetidos. (resposta 39)

2. associar de maneira mais clara signo e significado e ilustrar a situação e o ambiente. (resposta 171)

3. algumas informações deveriam ser explicitadas formulando-se um parágrafo entre o primeiro e o segundo para que alguns fatos como o que havia do outro lado da ilha, por exemplo, fossem entendidos, selecionar as idéias que realmente são importantes para a narrativa e explicitá-las de modo que sejam coesas com o que está sendo narrado; acrescentar mais informações para que a narrativa seja entendida como um todo de sentido. (resposta 81)

4. O uso convencional da linguagem é algo a ser estruturado e praticado. Creio que, pelo fato de ter apenas 10 anos, não consiga relacionar ainda estes convencionalismos da linguagem. (resposta 90)

5. Uma outra solução seria ler o texto em voz alta para que a criança fizesse uma relação entre a fala e a escrita e depois ela mesma pudesse fazer a correção. (resposta 118)

6. ao início do texto deve haver uma descrição mais detalhada do lugar para que se compreenda melhor o que pode passar nestas férias. (resposta 186)

7. seria mais proveitoso que o professor como mediador, fosse lentamente, porém gradativamente adaptando o aluno ( no caso a menina) ao uso correto das formas por meio da língua oral (a padrão) inicialmente fazendo-o perceber como fazemos tais ligações de modo natural e espontâneo, como por exemplo a tomada de termo, quando fazemos isso não repetimos pleonasticamente; ou invocamos sistematicamente a pessoa do discurso. Após perceberem estas funções que fazemos naturalmente e usamos, seria aconselhavel aplicar o pronome de reescrita de seu próprio texto corrigindo as possíveis inadequações e escolhendo dentro de um campo semântico as palavras a serem utilizadas. (resposta 172)

8. É claro que as alterações deste texto só poderão acontecer por pessoas que tem o conhecimento lingüistico, o que não acontece com a menina. Para o texto ser coeso e coerente é preciso que siga corretamente as estruturas de elaboração( principio, meio e fim), que tenha objetividade os fatos devem seguir uma ordem cronológica coerente para melhor entendimento. (resposta 186)

9. Mas, podem ser corrigidos através de leituras e incentivo a continuar produzindo textos, que a levarão ao melhoramento do raciocínio lógico e abstrato, sendo também aprimorados com o amadurecimento. Afinal de contas, se aprende a fazer, fazendo. (resposta 288)

Apoiando-se na cenografia construída pela questão, tais formandos imaginaram-se professores dessa menina dando indicações de como conduziriam seu trabalho com ela. Percebemos que essa condução seria voltada para uma prática pedagógica que tentaria levar a aluna ao domínio da norma culta com a transmissão de regras gramaticais e de normas para a produção de bons textos. Descartam-se, por exemplo, a leitura e discussão de textos de diferentes gêneros para que ela pudesse ampliar seu repertório e refletir acerca do conteúdo temático, estrutura composicional e estilo apresentados em cada um deles. Com isso, podemos afirmar que, no plano lingüístico, todas essas intervenções podem ser perpetuadoras 
de uma prática pedagógica voltada para a reprodução de modelos sem que se desenvolva a consciência crítica a respeito deles.

Há formandos que inserem, em sua resposta, palavras que indicam um contato com termos bastante usados na educação hoje em dia, a saber: "mediador", "incentivo", "amadurecimento". Esses termos aparecem em estudos desenvolvidos na área da Educação, o que pode revelar que eles tiveram, nas aulas de licenciatura, contato com tais preceitos educacionais, talvez mais facilmente interiorizados do que os estudos lingüísticos que deveriam ter sido discutidos na avaliação.

Baseando-se nessa imagem de professor, houve quem seguisse o perfil educacional bastante trabalhado nas licenciaturas e indicasse que "tudo isso não é caracterizado 'erro', pois o texto foi produzido por uma criança de apenas dez anos" (resposta 238). Indicar a idade da menina para considerar que sua produção não tem erro é colocar-se no lugar de alguém que a considera incapaz de conhecer bem a língua por causa de sua pouca experiência de vida e da baixa escolaridade. No entanto, essa poderia ser considerada uma visão atual no sentido de não centrar atenção nos erros dos alunos; no entanto, em termos lingüísticos, é uma visão extremamente tradicional, pois associa letramento a idade e escolaridade. Contrariamente a essa posição, essa menina pode ser vista como letrada, desde que consideremos os saberes envolvidos na sua competência de contadora de histórias.

Há quem afirme, ao comentar o texto "O outro lado da ilha", que ele "apresenta sérios problemas que tornam impossível o entendimento" (resposta 144). Partindo de seu ponto de vista, esse formando assume um modo de referir-se ao texto da menina que revela uma visão de texto como sendo um todo que apresenta o cumprimento de regras gramaticais e de organização, sem as quais não pode ocorrer a compreensão.

Indicando motivos para o texto estar incoerente, além de apresentar problemas de coesão, dois formandos elaboraram as seguintes justificativas:

Exemplo 77. Quando eles foram dormir, perceberam que os veados começaram a correr e fomos ver o que assustavam os animais, quando, de repente, um caranguejo gigante os atacaram. A mulher começa a chorar, dizendo que queria ir embora.

Devemos entender que é uma história de boa imaginação, mas não pode haver elementos que não fazem parte do contexto, como há, os bezerros. Também podemos corrigir o elo, onde termina a frase sem ter significado total, sendo assim usando somente a vírgula. Outro elo é o nome citado do personagem, fica vago, pois não foi citado anteriormente na história os nomes dos integrantes da família, portanto não era necessário o nome da personagem. (resposta 259)

Exemplo 78. O texto apresenta coesividade porém não é coerente, ou seja, não tem coerência até mesmo porque não faz sentido.

Caranguejo gigante não existe e bezerros em ilhas também não existe, por isso não tem 
coerência. Para ter um pouco de coerência eu tive que colocar em "meu texto" alguns outros substantivos, verbos etc. (resposta 56)

Esses dois formandos, centrando-se na coerência do texto-base, incomodaram-se com a presença de bezerros na ilha e com a indicação da existência de um caranguejo gigante. Um deles, para corrigir esse "problema", trocou os bezerros por veados, considerando mais provável a sua existência numa ilha. Ambos baseiam-se numa visão de texto como transmissor de verdades, de informações verdadeiras.

Observamos, nos indícios encontrados nessas respostas, que a leitura praticada pelos formandos associa-se a concepções apresentadas no capítulo II. Suas crenças a respeito da atribuição de sentido a textos norteiam sua prática leitora e os tornam reprodutores de um sentido suposto como pronto nos textos. Na maioria das vezes, tentam encontrar informações inquestionáveis produzidas por meio do respeito às regras gramaticais e à estrutura/organização das frases e parágrafos.

Tendo verificado isso em nosso corpus, não podemos deixar de considerar que a questão trazia para o aluno indicações de que a resposta deveria levar em consideração erros num texto produzido por uma criança. Dessa forma, já orientava o formando para um olhar voltado para as transgressões de regras. Sendo assim, entendemos que esses formandos estavam diante de uma situação difícil de ser transgredida, o que nos leva a relativizar o perfil de leitor levantado neste trabalho, pois não sabemos se, em outro evento, a prática de leitura seria diferente. De qualquer modo, o Provão 2001 direcionou a prática discursiva dos formandos ao propor uma questão que direcionava o trabalho para a discussão de falhas existentes num texto e desconsiderava seus aspectos positivos. Ao verificar a formação dos estudantes dessa maneira, desenhava-se como perfil pretendido de professor o de identificador de problemas textuais. 


\section{Consideracões finais}

Neste trabalho, apresentamos as principais concepções de leitura propostas por teóricos ao longo do tempo. Partindo dessas concepções e tendo como base a ligação entre leitura e produção de sentido, identificamos alguns parâmetros teóricos para garantirmos um entrelaçamento da visão de língua, sujeito, texto e relação autor/leitor. Com isso, buscamos mostrar algumas vozes presentes na constituição dos leitores, ou seja, dos formandos em Letras de 2001.

Para verificar a leitura realizada no Provão 2001, foram considerados os passos percorridos por esses formandos na direção de uma visão mais abrangente da atribuição de sentidos aos textos. Esse percurso ocorreu durante toda a vida desses sujeitos e não somente na graduação. Temos, assim, as respostas como um produto que carrega, em seu interior, indícios de toda a formação dos formandos e das condições de produção em que estavam envolvidos ao responderem à questão por nós analisada.

Ao testar nossas hipóteses iniciais, descobrimos que o estabelecimento de sentido para um texto realmente parte das crenças que se tem a respeito de sujeito, texto e língua(gem). No entanto, não podemos afirmar que as concepções de leitura só apareçam nos comentários dos formandos. Elas também aparecem na prática desenvolvida por esses sujeitos. Assim, a maior parte dos formandos revelou as concepções tradicional e estruturalista em seus comentários e, de mesmo modo, a prática mantida por eles nas reescritas que propuseram levou, de fato, em consideração os preceitos dessas duas mesmas concepções de leitura.

Nas respostas quantificadas em função da menção à compreensão (ou não) do textobase, observamos a ocorrência, nas 161 respostas, de tais concepções. Invariavelmente, referiam-se à facilidade ou dificuldade que tiveram em atribuir sentido ao texto da menina, indicando suas crenças a respeito do que seria necessário a um texto para que permitisse uma leitura bem sucedida. Em outras palavras, essas concepções se definem, nos textos dos formandos, em função da concepção de sentido que defendem, embora nunca, naturalmente, pela defesa explícita de uma dada concepção.

Mesmo sem a explicitação de uma concepção de leitura (e de sentido), nas 290 respostas dos formandos (e não somente nessas 161), pudemos observar, portanto, como foi realizada a leitura da questão e do texto "O outro lado da ilha". Ora, essa prática não pode ser considerada desvinculada das crenças que os sujeitos têm a respeito da atividade leitora, e essas crenças tornam-se perceptíveis, por exemplo, graças às escolhas lexicais feitas pelos 
formandos, à maneira como eles respondem à questão e como se referem ao texto da menina (ou à própria menina como produtora do texto ou como aluna). Essas escolhas integram as respostas analisadas e constituem o entrelaçamento das concepções de leitura, permitindo que se verifique a prática de leitura desses formandos no contexto enunciativo do Provão.

Assim, acreditamos que o sujeito seja co-responsável pelo que lê, em virtude das diferentes condições de produção, dando lugar a que um mesmo texto possa ser lido de diferentes maneiras, por diferentes leitores ou pelo mesmo leitor em diferentes épocas. No contexto enunciativo do Provão, temos de considerar também que o modo de acesso ao texto é um fator determinante do seu sentido e contribui para a ativação de um modo de leitura, isto é, contribui para que certas representações do leitor sejam ativadas no momento da leitura (Corrêa, 2006c).

Dentre as considerações que fizemos a esse respeito, destacamos a de que os formandos, ao pretenderem responder à questão revelando os conhecimentos lingüísticos necessários para a tarefa, afastaram-se de uma visão mais crítica da questão proposta, de um diálogo com a autora e com o texto propriamente dito, realizando uma atividade de leitura mais voltada ao que é previsto pelas concepções tradicional e estruturalista.

Evidências nos textos analisados, no entanto, indicam que essa prática nos revela a historicidade da constituição desses leitores, marcada pela disseminação de discursos normativos. Essa prática parece estar sendo fortemente mantida pelas escolas e pelas universidades.

Assim sendo, numa situação extremamente tensa como a de uma avaliação de caráter nacional, acionaram o modelo de leitura que lhe fosse correspondente; daí uma possível explicação para os dados encontrados neste trabalho. Era, portanto, uma situação difícil de ser transgredida, já que, nas respostas dos formandos, há, pode-se dizer, uma tendência a adotar um discurso didático. A própria reescrita do texto-base, que simula o acompanhamento da produção textual de um aluno pelo professor, é, nesse seu caráter de simulacro de uma situação de ensino-aprendizagem, um procedimento didático. No entanto, mesmo em textos em que os formandos apenas analisam o texto-base, há uma tendência a abordá-lo de um ponto de vista didático, sempre com a característica de dominância da imagem do professor quanto ao objeto de discurso (no caso, a coesão) sobre a imagem do aluno.

No material analisado, como vimos, as vozes observadas nas respostas dos formandos podem ser associadas aos discursos comumente encontrados na escola, indicando o papel do professor como o de ter de lidar com as falhas de seus alunos. 
Ainda refletindo acerca do tipo de questão proposta, não podemos nos esquecer de que a relação que se estabelece com o sentido está vinculada ao enunciado de que ele é réplica. $\mathrm{O}$ contexto enunciativo é constitutivo do enunciado, tanto na história de longa duração como na relação entre enunciados. Grossmann (1996), ao afirmar que o sujeito se apropria de dispositivos semióticos elaborados durante a história humana, capazes de orientar a interpretação a ser feita de um texto, lembra que essa apropriação pode ser feita a partir da indicação prévia do gênero a que pertence o texto ou de alguma retomada lexical para que o leitor não deixe de compreender uma parte importante do texto.

Ao reconhecermos problemas na formulação da questão, não pretendemos desconsiderar o papel do formando/leitor como se a responsabilidade pela atribuição de sentido nascesse exclusivamente daquela formulação. Não se pode, pois, afirmar simplesmente que os formandos realizaram uma leitura equivocada induzidos pela má formulação da questão e, por isso, não obtiveram um bom resultado. De todo modo, imersos numa situação adversa, eles tiveram que recorrer à sua memória discursiva para acionar os dispositivos que consideravam mais adequados para a realização do exame. A escolha que realizaram para direcionarem sua resposta está, pois, intimamente ligada às suas práticas de leitura e escrita.

Consideramos que as avaliações (sejam elas realizadas na escola ou elaboradas por órgãos responsáveis por verificar o desempenho dos estudantes em nível nacional, como era o caso do Provão) precisariam mudar sua proposta de exercício, talvez buscando uma visão positiva do texto da menina, ao solicitar, por exemplo, justificativas para as escolhas que ela fez em seu texto. Desse modo, os examinandos poderiam revelar suas leituras sem se preocuparem tanto com um único sentido correto.

Ligadas a essa visão positiva do texto, parece-nos que se fazem necessárias duas grandes mudanças urgentes para o ensino de leitura no Brasil: uma maior consideração das vozes presentes nos discursos que permitem as possibilidades de leitura de um texto e um maior zelo nas correções de produções para que estas não alterem completamente o texto original nem imponham a leitura do professor como única possibilidade de acerto.

Somente quando incorporarmos a visão de leitura como atividade multifacetada, uma vez que, enquanto prática social, mobiliza o interdiscurso e traz à tona os dizeres do outro, o leitor, sujeito histórico, poderá perceber-se como inscrito, de acordo com suas filiações e vivências, numa disputa de interpretações, de modo que o sentido não seja mais visto como único e determinado pelo autor. Assim, autor e leitor serão vistos como co-responsáveis pela interpretação de um determinado texto: o primeiro, partindo da materialidade lingüística para 
buscar, numa ilusão quanto à formulação precisa, o sentido do texto; o segundo, imaginando um autor para o texto e calculando a relação que este terá mantido com o que pretendia dizer, de modo a chegar à correspondente ilusão de apreensão precisa do sentido. Com uma nova representação sobre o que seja a leitura, poderíamos, talvez, daqui a alguns anos, ganhar uma maior possibilidade de negociação durante as aulas, pois aos textos poderiam ser levantados sentidos possíveis e não o sentido autorizado pelo professor ou pelo livro didático. 


\section{Bibliografia}

AUTHIER-REVUZ, J. Heterogeneidade mostrada e heterogeneidade constitutiva: elementos para uma abordagem do outro no discurso. In: Entre a transparência e a opacidade. Porto Alegra: EDIPUCRS, 2004, p. 11-80.

. Heterogeneidade(s) enunciativas(s). In: Caderno de estudos lingüísticos. Campinas, v. 19, 1990, pp. 25-42.

. Palavras incertas.Campinas-SP: Editora da Unicamp, 1998.

BAKHTIN, Mikhail. Estética da criação verbal. 4 ed. Tradução de Paulo Bezerra. São Paulo: Martins Fontes, 2003. (Título original: Estetika Sloviésnova Tvórtchestva, 1979).

. Marxismo e filosofia da linguagem. 11 ed. Tradução de Michel Lahud e Yara

Frateschi Vieira. São Paulo: Hucitec, 2004. (Título original: Marksizm i filossófia iaziká, 1929).

BARBOSA, José Juvêncio. Alfabetização e leitura. 2 ed. São Paulo; Cortez, 1992.

BARROS, Diana Luz Pessoa de. Teoria do discurso: fundamentos semióticos. 3 ed. São Paulo: Humanitas, 2002.

BEZERRA, Maria Auxiliadora. Perfil real, perfil ideal do professor de Língua: avaliação do Exame Nacional de Letras. IN: Linguagem \& Ensino, Pelotas, v. 6, n. 2, p. 81-105, jul./dez. 2003

BRANDÃO, Helena H. Nagamine. Escrita, leitura, dialogicidade. In: BRAIT, Beth (org.). Bakhtin, dialogismo e construção de sentido. Campinas: Editora da UNICAMP. p. 281-290.

BRASIL. Ministério da Educação e do Desporto. Secretaria do Ensino Fundamental, Parâmetros Curriculares Nacionais de Língua Portuguesa.

BRITTO, Luiz Percival Leme. Leitura e política. In: Leitura : teoria \& prática. Revista semestral da Associação de Leitura do Brasil. Número 33. Campinas: Mercado Aberto, junho / 1999. 
CAGLIARI, Luiz Carlos. "A leitura”. IN: Alfabetização \& Lingüística.10 ed. São Paulo: Scipione, 2001. p. 148-181. (Coleção Pensamento e ação no Magistério)

CAVAllo, G e CHARTIER, R. (orgs.). História da leitura no mundo ocidental. São Paulo: Ática, 1998.

CHARAUDEAU, P \& MAINGUENEAU, D. Condições de produção e Memória discursiva. Dicionário de Análise do Discurso. Coordenação da tradução: Fabiana Komesu. São Paulo: Contexto, 2004, p. $114-5$ e p. 325-6.

CHARTIER, R. (org). Práticas da leitura. 2 ed. São Paulo: Estação Liberdade, 2001. (Título orginal: Pratiques de la lecture - 1985).

COLOMER e CAMPS. Ensinar a ler, ensinar a compreender. Tradução: Fátima Murad. Porto Alegre: Artmed, 2002. (Título original: Enseñar a leer, enseñar a comprender - 1996).

CORACINI, Maria José R. Faria. Concepções de leitura na (pós-)modernidade. In: LIMA, Regina Célia de Carvalho Paschoal (org.). Leitura: múltiplos olhares. Campinas, SP: Mercado de Letras; São João da Boa Vista, SP: Unifeob, 2005, pp. 15-44.

CORRÊA, Manoel Luiz Gonçalves. Leitura e produção de textos: processos interferentes. Estudos Lingüisticos XXIII. Anais de Seminários do GEL. Vol. I. São Paulo, 1994, pp. 104- 110.

Relações intergenéricas na análise indiciária de textos escritos. Trabalhos em Lingüística Aplicada. Volume 45 (2). Campinas: Instituto de Estudos da Linguagem, 2006a, p. 205-224.

. Práticas de leitura e escrita: breve nota sobre a relação entre o verbal e o não verbal. Contrapontos, Itajaí (Santa Catarina). V.6, n.2, p.293-302, 2006b.

. A produção escrita de formandos em letras: a experiência do provão. In: Marilza de Oliveira (Org.). Língua Portuguesa em São Paulo: 450 anos. São Paulo: Associação Editorail Humanitas, 2006c, p. 141-165.

CORTINA, Arnaldo. Leitura como processo de compreensão e de interpretação: O príncipe e seus leitores. Orientador: Prof. Dr. José Luiz Fiorin. São Paulo: FFLCH - USP, 1994 (Tese de Doutorado em Lingüística). 
DIJK, Teun Adrianus van. Cognição, discurso e interação. São Paulo: Contexto, 1992. (Caminhos da Lingüística)

FLORENCIO, Ana Maria Gama. A leitura discursiva e seus múltiplos efeitos de sentido. Disponível em: http://www.el-libro.com.ar/31feria/educativas/html/PDFs/5-002-Florencio.pdf.. Acesso em 30 out. 2005.

FOUCAULT, Michel. A ordem do discurso. Trad. L.F.A. Sampaio. São Paulo: Loyola. Tradução do francês: L'ordre du discours - 1971.

GADET, F. e HAK, T. (orgs.) Por uma análise automática do discurso: uma introdução à obra de Michel Pêcheux. Tradução de Bethânia Mariani, Eni Orlandi, Jonas Romualdo, Lourenço Cacon Filho, Manoel G. Corrêa, Maria Augusta de Matos, Péricles Cunha, Silvana Serrani e Suzy Lagazzi. Campinas,SP: Editora da Unicamp, 2001. (Título original: Towards na automatic discurse analysis, 1997).

GINZBURG, C. Sinais: raizes de um paradigma indiciário. In: Mitos, emblemas, sinais: morfologia e historia. São Paulo: Companhia das Letras, 1989.

GRAFF, Harvey. Os labirintos da alfabetização: reflexões sobre o passado e o presente da alfabetização. Porto Alegre: Artes Médicas, 1995. Tradução de Tirza Myga Garcia.

GROSSMANN, Francis. Enfances de la lecture: manières de faire, manières de lire à l'école maternelle. Bern/Berlin/Frankfurt-M/New York/ Paris/Wien: Peter Lang, 1996.

Instituto Nacional de Estudos e Pesquisas Educacionais (1999). Exame Nacional do Ensino Médio: Documento Básico 2000. Brasília: INEP.

KLEIMAN, Angela. Leitura: ensino e pesquisa. 2 ed. Campinas: Pontes, 2004a (1 ${ }^{\text {a }}$ ed. 1989). Oficina de leitura.Campinas: Pontes, 1993. Texto \& leitor: aspectos cognitivos da leitura. 9 ed. Campinas: Pontes, 2004b (1 ${ }^{\mathrm{a}}$ ed. 1989).

KOCH, Ingedore Grunfeld Villaça. Concepções de língua, sujeito, texto e sentido. In: Desvendando os segredos do texto. 2 ed. São Paulo: Cortez, 2003. (pp. 13 - 20) 
LAJOLO, Marisa. Do mundo da leitura para a leitura do mundo. 6 ed. São Paulo: Ática, 2004 (Série Educação em Ação) 1ª ed. 1994.

MACHADO, Tertuliana Corrêa. A formação do aluno leitor. Dissertação sob orientação do Prof. Dr. Francisco Antonio Pereira Fiaho. Universidade de Santa Catarina. Florianópolis, 2001.

MAINGUENEAU, Dominique. Análise de textos de comunicação. Tradução de Cecília P. de Souza-eSilva e Décio Rocha. 3 ed. São Paulo: Cortez, 2004. (Título original: Analyser les textes de communication, 2001)

A cena enunciativa. Novas Tendências em Análise do Discurso. 3. ed. Campinas: Pontes, 1997, p. 29-52. (Tradução de Freda Indursky. Título orgiginal: Nouvelles tendances en Analyse du Discours, 1987).

MARCUSCHI, Luiz Antônio. Da fala para a escrita: atividades de retextualização. 4 ed. São Paulo: Cortez, 2003 (1 $1^{\mathrm{a}}$ ed. 2000).

O papel da Lingüistica no ensino de línguas. (2000a) Disponível em: < www.marcosbagno.com.br/conteudo/forum/marcuschi.htm> . Acesso em: 17/12/2003.

. Anáfora indireta: o barco textual e suas âncoras. In: Revista de Letras da UFPR. Curitiba, UFPR, 2001b - versão revista do texto apresentado IV Jornada do CELSUL UFPR, em novembro/2000b.

MARTINS, Maria Helena. O que é leitura?. 19 ed. São Paulo: Brasiliense, 1995 (1ª ed. 1982) Coleção Primeiros passos no 74.

MENEGHEL, Stela e LAMAR, Adolfo Ramos. Avaliação como construção social - reflexões sobre as políticas de avaliação da educação no Brasil. In: SOBRINHO, José Dias e RISTOFF, Dilvo I. (org.). Avaliação democrática: para uma universidade cidadã. Florianópolis: Insular, 2002, pp. 145164.

ORLANDI, Eni Puccinelli. Análise de discurso: princípios \& procedimentos. 5 ed. São Paulo: Pontes, 2003. ( $1^{\text {a }}$ ed. 1999) 
PAZ, Dioni Maria dos Santos. Formação de conceitos de leitura: relação com a cognição e os processos de significação. IN: http://www.ufsm.br/linguagem_e_cidadania/02_03/Dioni.htm. Acesso em 21 mai. 2004.

PÊCHEUX. M. O discurso: estrutura ou acontecimento. Tradução: Eni P. Orlandi. 3. ed. Campinas, SP: Pontes, 2002.

POSSENTI, Sírio. Sobre a leitura: o que diz a Análise do Discurso? In: MARINHO, Marildes (org.). Ler e navegar: espaços e percursos da leitura. Campinas, SP: Mercado de Letras: Associação de Leitura do Brasil, 2001, pp. 19-30 (Coleção Leituras no Brasil).

RISTOFF, Dilvo e LIMANA, Amir. O Enade como parte da avaliação da educação superior (2004). Disponível em: < http://www.fajopa.edu.br/banner/enade.htm>. Acesso em: 25 jun. 2005.

SOARES, Magda. Letramento: um tema em três gêneros. Belo Horizonte: Autêntica, 1998.

Letrar é mais que alfabetizar. Entrevista concedida ao Jornal do Brasil. 26/11/2000. Disponível em: <http://intervox.nce.ufrj.br/ edpaes/magda.htm> Acesso em 20 jun. 2007.

STREET, Brian. Perspectivas interculturais sobre o letramento. In: VERHOEVEN, Ludo (ed.) Functional Literacy: theoretical issues and educational implications. Amsterdan / Philadelphia. 1994. pp. 95-111. Tradução de Marcos Bagno. Revista de Filologia e Lingüística Portuguesa. n.8, no prelo.

TFOUNI, Lêda Verdiani. Perspectivas Históricas e a-históricas do letramento. Caderno de Estudos Lingüisticos $n^{\circ} 26$. Campinas, 1994. pp. 49-62.

ZILBERMAN, Regina. Fim do livro, fim dos leitores? São Paulo: Editora SENAC, 2001, p. 86 (Coleção Ponto Futuro, volume 3).

O Exame Nacional de Cursos e o sistema de avaliação da Educação Superior (2001). Disponível em: $<$ http://www.INEP.gov.br/superior/provao/sintese/sintese2001.htm>. Acesso em 14 jul. 2005. 


\title{
$\underline{\text { Anexos }}$
}

\section{Anexo A}

\section{OFÍCIO INEP/DAES N $N^{0} \quad 001708 / 2002$}

Brasília, 2 de abril de 2002

\section{Senhor Professor,}

Em atendimento à sua solicitação, e tendo em vista o interesse acadêmico do seu Projeto de Pesquisa "O Exame Nacional de Cursos e as Práticas de Leitura e Escrita de Formandos em Letras" estaremos repassando os dados solicitados no item A (caracterização dos produtores do texto com base no questionário respondido). Estamos autorizando a FCC a providenciar as cópias dos textos produzidos pelos graduandos, na parte discursiva da Prova do ENC de 2001, para constituir o acervo necessário aos seus estudos, com as devidas precauções para garantia do sigilo. Entretanto o custo dessas cópias deverá ser coberto, pois este Instituto não tem condições de financiá-lo. O senhor poderá procurar a Profa. Glória Maria Santos Pereira Lima, da FCC, para combinar os procedimentos, datas e cobertura dos custos.

Tão logo estudos sejam produzidos pelo senhor, este Instituto apreciaria conhecê-los.

\author{
Atenciosamente, \\ (assinatura) \\ Trancredo Maia Filho \\ Diretor da DAES
}

ILMO. SR.

Professor Manoel Luiz Gonçalves Corrêa

Universidade de São Paulo

SÃO PAULO - SP

Fax (11) 3819-9026 goncor@terra.com.br 


\section{Anexo B}

Texto original, publicado em Marcuschi 2000b

\begin{tabular}{|l|}
\hline O outro lado da ilha \\
\hline Essa história começa com uma família que vai a uma ilha passar suas \\
férias. Quando eles chegam eles vão logo explorando a ilha e explodem uma \\
barreira que os impediam de passar para o outro lado da ilha. \\
Quando eles foram dormir eles perceberam que os bezerros começaram \\
a correr e que quando eles foram ver o que estava assustando os bezerros. \\
Quando eles de repente, com uma patada só um caranguejo gigante os \\
atacou. Debora que era sua ezposa começou a chorar dizendo que queria ir \\
embora. \\
Quando amanheceu eles foram ver como estava o barco, para ir embora \\
e perceberam que o barco não estava lá. Os homens sairam para explorar a \\
ilha, e no meio do caminho encontraram um caranguejo que estava no \\
penhasco. Eles não quizeram saber e atiraram no caranguejo que caio \\
ribancera a baixo. Mais o marido de Debora, desmaiou e seu irmão não tinha \\
como ajudá-lo, por isso foi chamar ajuda. Quando chegou em casa chamou \\
logo seu sobrinho Ivan para ajudar ele a trazer seu irmão. Quando os dois \\
chegaram lá ele não estava mais lá. Quando eles estavam voltando, Ivan teve \\
a idéia de fazer um farol com a torre que havia na ilha. Ele foi com sua prima \\
e com seu cachorro. E tudo deu certo, mas quando eles estavam indo embora \\
da ilha, os caranguejos estavam na porta da torre fazendo com que eles não \\
pudessem sair daquele labirinto. Eles dois tiveram várias idéias mais \\
nenhuma dava certo. Em casa Debora havia avistado seu marido chegando \\
com um homem. Na torre Ivan teve a idéia de jogar a lanterna a querozene \\
nos caranguejos. Quando eles jogaram-na nos caranguejos eles sairam \\
correndo em direção a mata e com isso a mata pegou fogo. Da casa dava pra \\
ver o fogo, então todos saíram correndo para apagar o fogo. Eles apagaram o \\
fogo e foram dormir e quando acordaram avistaram um barco e foram \\
embora.
\end{tabular}

